\title{
PROPORÇÕES DE NITRATO E AMÔNIO NA NUTRIÇÃO E PRODUÇÃO DOS CAPINS ARUANA E MARANDU
}

\author{
JORGE HENRIQUE DA SILVA SANTOS
}

Dissertação apresentada à Escola Superior de Agricultura "Luiz de Queiroz", Universidade de São Paulo, para obtenção do título de Mestre em Agronomia. Área de Concentração: Solos e Nutrição de Plantas.

PIRACICABA

Estado de São Paulo - Brasil Julho - 2003 


\title{
PROPORÇÕES DE NITRATO E AMÔNIO NA NUTRIÇÃO E PRODUÇÃO DOS CAPINS ARUANA E MARANDU
}

\author{
JORGE HENRIQUE DA SILVA SANTOS
}

Engenheiro Agrônomo

Orientador: Prof. Dr. FRANCISCO ANTONIO MONTEIRO

Dissertação apresentada à Escola Superior de Agricultura "Luiz de Queiroz", Universidade de São Paulo, para obtenção do título de Mestre em Agronomia. Área de Concentração: Solos e Nutrição de Plantas.

PIRACICABA

Estado de São Paulo - Brasil

Julho -2003 


\section{Dados Internacionais de Catalogação na Publicação (CIP) DIVISÃO DE BIBLIOTECA E DOCUMENTAÇÃO - ESALQ/USP}

\section{Santos, Jorge Henrique da Silva}

Proporções de nitrato e amônio na nutrição e produção dos capins aruana e marandu / Jorge Henrique da Silva Santos. - - Piracicaba, 2003.

$81 \mathrm{p}$.

Dissertação (mestrado) - - Escola Superior de Agricultura Luiz de Queiroz, 2003.

Bibliografia.

1. Amonio 2. Capim aruana 3. Capim marandu 4. Nitrato 5. Solução nutritiva I. Título

CDD 633.2 


\section{À Deus}

"Que nos deu o dom da vida, nos preencheu com a liberdade, nos abençoou com a inteligência, nos deu a graça de lutarmos, para a conquista de realizações, cabe $o$ louvor e a glória. A nós só cabe agradecer."

Rui Barbosa

Aos meus pais Carlos Alberto "in memorian" e Edméa pelo amor, confiança, dedicação e incentivo inestimado,

\section{AGRADEÇO}

Ao meu avô José pelos ensinamentos, ̀̀ minhas tias Yolanda, Jolanda e Edna e a toda minha família pelo grande incentivo. À Jussiara pelo companheirismo, momentos alegres e carinho. Ao Sr. Dinho e Sra. Julia e familiares pela atenção e incentivo. À Fabio, Alécia e ao meu afilhado Vinícius, 


\section{AGRADECIMENTOS}

Ao Prof. Dr. Francisco Antonio Monteiro pela confiança, orientação e amizade.

À Escola Superior de Agricultura "Luiz de Queiroz" e a Coordenação do Programa de Pós-Graduação em Solos e Nutrição de Plantas pela oportunidade de realização do curso.

Aos professores Quirino Augusto de Camargo Carmello e Antonio Roque Dechen pela colaboração nas atividades de pesquisa e amizade.

À CAPES pela concessão da bolsa de estudos e apoio institucional.

Às grandes amizades desenvolvidas: Karina Batista, Simão Lindoso, Gláucia Yorinori, José Lavres, Sandrinha, Edna Bonfim, João de Deus, Gláucia Anti, Suzana Mello, Tales Muller, Marcelo.

Aos estagiários da Nutrição Mineral de Plantas, Jussiara Vendemiatti, Tiago Maique, Dylnei Consolmagno, Simeire Manarin, Humberto Neto pela amizade e colaboração no desenvolvimento do experimento.

Às funcionárias do Departamento de Solos e Nutrição Mineral de Plantas, Nancy Amaral, Sueli Bovi, Lúcia Forti, Ednéia Mondoni, Lurdes González, Nivanda Moura e Flávia pela amizade e contribuição nas análises.

Aos professores e colegas do Curso de Solos e Nutrição de Plantas e outros departamentos. Aos colegas e amigos do futebol dos sábados à tarde pela convivência, companheirismo e momentos de lazer. 


\section{SUMÁRIO}

\section{Página}

RESUMO... vii

SUMMARY.... ix

1 INTRODUÇÃO. 1

2 REVISÃO DE LITERATURA................................................................... 3

2.1 Origem e características dos capins Aruana e Marandu.................................... 3

2.1.1 Capim-Aruana .................................................................................... 3

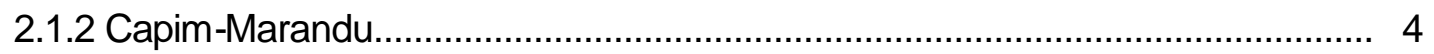

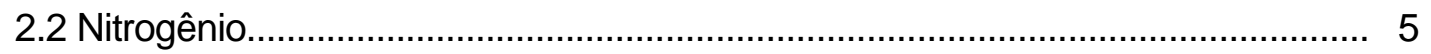

2.2.1 Nitrogênio nas plantas e na adubação de pastagens...................................... 5

2.2.2 Nitrato e amônio nos solos e nas plantas.................................................... 10

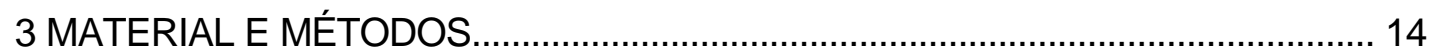

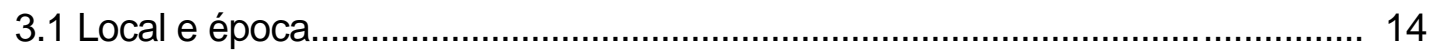

3.2 Delineamento experimental e tratamentos.......................................................... 14

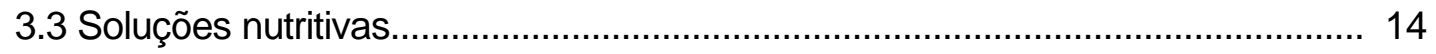

3.4 Instalação e condução do experimento........................................................ 15

3.5 Coleta do material vegetal........................................................................... 16

3.6 Determinações no material vegetal................................................................. 16

3.6.1 Atividade da redutase do nitrato................................................................. 16

3.6.2 Estimativa da concentração de clorofila..................................................... 17

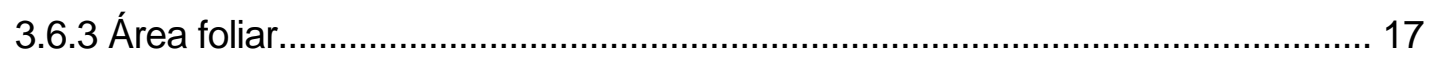

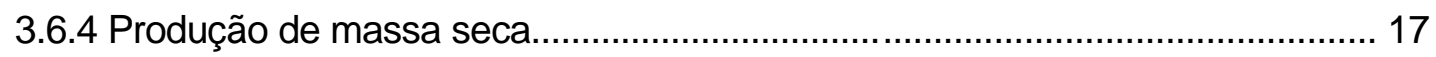

3.6.5 Concentração de nitrogênio total................................................................18

3.6.6 Concentração de nitrogênio nas formas de amônio e nitrato.............................. 18

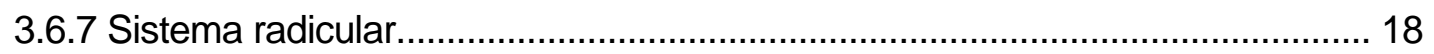

3.7 Análise Estatística.................................................................................... 19 
4 RESULTADOS E DISCUSSÃO...................................................................... 20

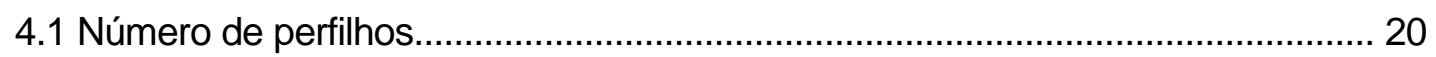

4.2 Número de folhas................................................................................... 23

4.3 Estimativa do teor de clorofila através de unidades SPAD................................. 26

4.4 Atividade da redutase do nitrato............................................................................ 29

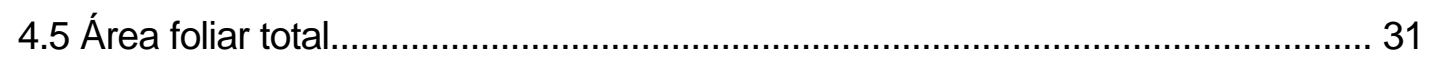

4.6 Produção de massa seca da planta.............................................................. 34

4.6.1 Produção de massa seca da parte aérea da planta.......................................... 34

4.6.2 Produção de massa seca das raízes................................................................ 38

4.7 Concentração de nitrogênio total nas plantas.................................................... 40

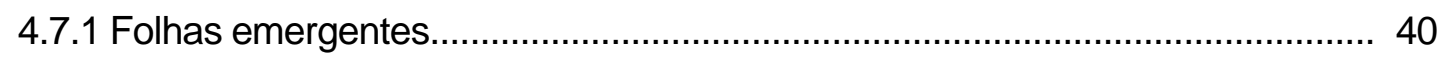

4.7.2 Lâminas de folhas recém-expandidas....................................................... 42

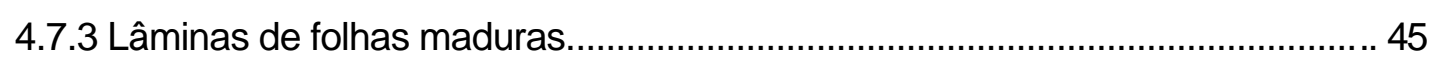

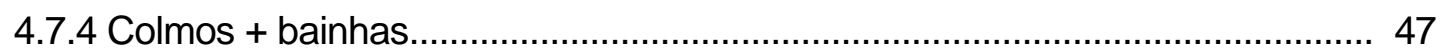

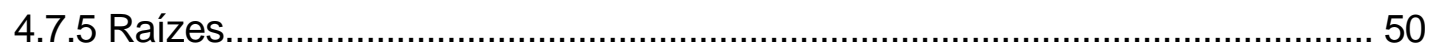

4.8 Concentração de nitrato nas plantas............................................................... 52

4.8.1 Folhas emergentes, Lâminas de folhas recém-expandidas,

Lâminas de folhas maduras e Colmos mais bainhas.................................................. 52

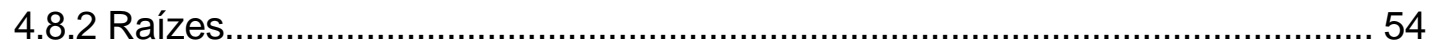

4.9 Concentração de amônio nas plantas.............................................................. 56

4.9.1 Folhas emergentes, Lâminas de folhas recém-expandidas,

Lâminas de folhas maduras e Colmos mais bainhas..................................... 56

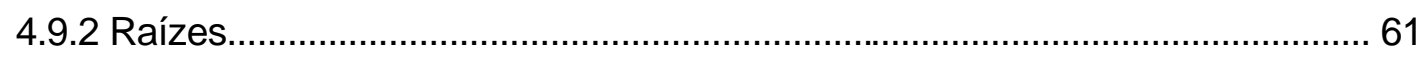

4.10 Relação nitrato/amônio nas plantas............................................................... 62

4.10 .1 Folhas emergentes, Lâminas de folhas recém-expandidas,

Lâminas de folhas maduras e Colmos mais bainhas..................................... 62

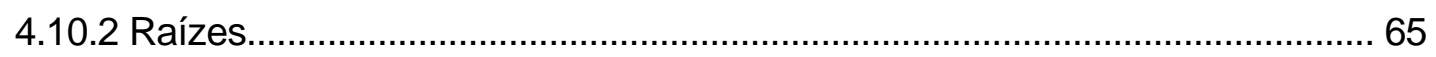

4.11 Superfície e comprimento total do sistema radicular....................................... 67

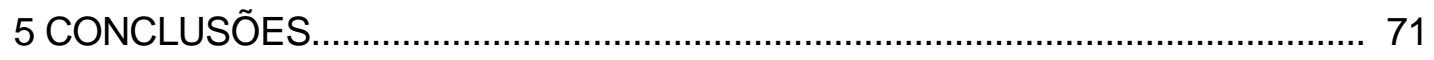

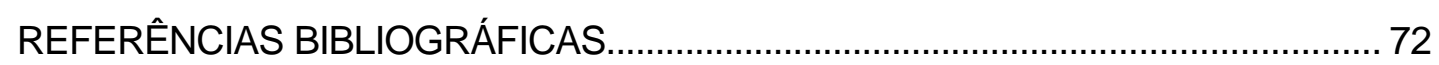




\title{
PROPORÇÕES DE NITRATO E AMÔNIO NA NUTRIÇÃO E PRODUÇÃO DOS CAPINS ARUANA E MARANDU
}

\author{
Autor: JORGE HENRIQUE DA SILVA SANTOS \\ Orientador: Prof. Dr. FRANCISCO ANTONIO MONTEIRO
}

\section{RESUMO}

Foi conduzido experimento em casade-vegetação do Departamento de Solos e Nutrição de Plantas da ESALQ - USP, durante o período de fevereiro a maio de 2002 , com o objetivo de avaliar respostas produtivas, fisiológicas e nutricionais a proporções de nitrato e amônio, das forrageiras Panicum maximum cv. Aruana e Brachiaria brizantha cv. Marandu, cultivados em solução nutritiva, utilizando sílica como substrato. Foi empregado o delineamento experimental de blocos completos ao acaso, com quatro repetições e seis tratamentos. O nitrogênio foi estudado na dose de $210 \mathrm{mg} \mathrm{L}^{-1} \mathrm{e}$ nas proporções respectivas de nitrato e amônio de 100/0; 85/15;70/30; 55/45; 40/60 e $25 / 75 \%$. As soluções foram preparadas a partir da solução completa de Sarruge (1975), devidamente modificada para as proporções desses íons no suprimento de nitrogênio. Dois corte foram realizados nas plantas, separando-se os componentes da parte aérea em folhas emergentes, lâminas de folhas recém-expandidas, lâminas de folhas maduras e colmos mais bainhas. Após o segundo corte, as raízes foram separadas da sílica e lavadas. Durante o crescimento das plantas foram determinados a atividade da redutase do nitrato e o valor SPAD e na ocasião dos cortes foram contados os perfilhos e as folhas das plantas e foi medida a área foliar. No material seco foi obtido a produção de massa e nas amostras moídas foram determinadas as 
concentrações de nitrogênio total, de nitrato e de amônio. Nas raízes foram avaliadas a superfície e comprimento total. As proporções de 85/15 a 55/45 de nitrato/amônio propiciaram aumento do número de perfilhos e de folhas. A área foliar e a massa seca da parte aérea responderam positivamente ao nitrogênio fornecido em proporção 100/0 a 55/45 de nitrato/amônio. A massa seca, a superfície e o comprimento de raízes foram beneficiadas pelo fornecimento de nitrato/amônio em proporções de 70/30 e 55/45. A aplicação de nitrato e amônio nas proporções de 40/60 e 25/75 resultou em mais elevada concentração de nitrogênio total nos colmos mais bainhas e de amônio nas lâminas de folhas maduras. Os atributos produtivos dos capins foram prejudicados pelo uso da proporção de nitrato/amônio de 25/75. A inclusão de amônio em substituição de parte do nitrato na solução completa de Sarruge beneficia os capins estudados. 


\title{
NITRATE AND AMMONIUM PROPORTIONS FOR ARUANA AND MARANDU GRASSES NUTRITION AND PRODUCTION
}

\author{
Author: JORGE HENRIQUE DA SILVA SANTOS \\ Adviser: Prof. Dr. FRANCISCO ANTONIO MONTEIRO
}

\section{SUMMARY}

A greenhouse experiment was carried out in the Soils and Plant Nutrition Department, at ESALQ-USP from February to May 2002. The objective was to evaluate the response in relation to proportions of nitrate and ammonium in the nutrient solutions of Panicum maximum cv. Aruana and Brachiaria brizantha cv. Marandu. Plants grew in a ground quartz substrate. The experiment was set in complete randomized block design, with four replications. Nitrogen at $210 \mathrm{mg} \mathrm{L}^{-1}$ was studied in proportions 100/0; $85 / 15 ; 70 / 30 ; 55 / 45 ; 40 / 60$ and $25 / 75 \%$ of nitrate and ammonium, respectively. A complete Sarruge (1975) solution was modified to supply nitrogen in the studied proportions. Plants were harvest twice and plant tops was separated in emerging leaves, lamina of recently expanded leaves, lamina of mature leaves and steams plus sheaths. After the second harvest, roots were taken from the substrate and washed. During the growth period the nitrate reductase activity and SPAD units were determined and at the plant harvesting the number of tillers and leaves were counted and leaf area was measured. Dry matter yield was obtained in the oven, dry plants and the concentration of total nitrogen, nitrate and ammonium were determined in the ground 
sample. Roots were evaluated for the total surface and length. Increases in the number of tillers and leaves were found with the $85 / 15$ to $55 / 45$ proportions of nitrate/ammonium. Leaf area and plant tops dry weight positively responded to the nitrogen supplied form $100 / 0$ to $55 / 45$ as nitrate/ammonium. Nitrate and ammonium applied in the 40/60 and 25/75 proportions showed the highest total nitrogen concentration in stems plus sheaths and the highest ammonium concentration in the lamina of mature leaves. Grasses production was decreased by the use of nitrate/ammonium at 25/75 proportion. The inclusion of ammonium as part of the nitrogen supply in the Sarruge's nutrient solution is beneficial to the studied forage grasses. 


\section{INTRODUÇÃO}

Estimase que a área ocupada por pastagens no Brasil corresponde a 30\% do total da área agricultável, o que evidencia a importância das plantas forrageiras para a agropecuária nacional, basicamente por se tratar a pastagem da principal fonte para a alimentação animal. Do total das forrageiras nas pastagens, em torno $85 \%$ é preenchido pelas braquiárias e, em menor proporção, com os capins do gênero Panicum.

Nas pastagens tropicais a capacidade de rendimento de massa forrageira é reduzida por problema de baixa fertilidade dos solos, podendo-se verificar que a disponibilidade de nitrogênio é insuficiente para atender as exigências nutricionais das gramíneas forrageiras, de tal forma que há menos área fotossintetizante, baixas concentrações de clorofila e de proteína nas plantas, além do comprometimento na produção de forragem.

O nitrogênio, elemento abundante na atmosfera na forma de ke (chegando a compor $78 \%$ do ar atmosférico), faz-se presente em baixos teores na maioria dos solos. Porém, é o nutriente requisitado em maior quantidade pelas plantas, principalmente por causar grande impacto no desenvolvimento e no incremento da produção de gramíneas forrageiras. Assim, a utilização da adubação nitrogenada tem sido muito estudada, devido a essa necessidade para a nutrição e produção das plantas forrageiras.

A denominação de cultivar Marandu foi dada a um ecótipo de Brachiaria brizantha estudado pelo Centro Nacional de Pesquisa de Gado de Corte (EmbrapaCNPGC), localizado em Campo Grande, MS. Em 1979, esse cultivar foi encaminhado ao Centro de Pesquisa Agropecuária dos Cerrados (Embrapa-CPAC), localizado em Planaltina, DF, para desenvolvimento de mais alguns estudos. Em 1984, o cultivar Marandu foi lançado e liberado pela Embrapa, como mais uma alternativa de gramínea 
forrageira para a implantação e/ou substituição de pastagens. Entretanto, esse capim exige solos férteis para que possa expressar melhor o seu potencial produtivo. Essa gramínea forrageira tem apresentado excelente desempenho quando submetida à adubação nitrogenada e tem demonstrado elevado potencial de produção de massa seca e perfilhamento.

Devido a grande importância das plantas forrageiras da espécie Panicum maximum para o Brasil, o Instituto de Zootecnia, da Secretaria de Agricultura e Abastecimento do Estado de São Paulo, localizado no município de Nova Odessa, SP, lançou no mercado um cultivar dessa espécie, o capim-Aruana, ampliando as opções para a utilização em pastagens. Para esse capim existem poucos estudos envolvendo a influência do nitrogênio no rendimento de massa seca, perfilhamento e valor nutritivo.

Objetivou-se avaliar as respostas das forrageiras Panicum maximum cv. Aruana e Brachiaria brizantha cv. Marandu, cultivadas em solução nutritiva, ao fornecimento de nitrogênio em proporções de nitrato e amônio, quanto ao número de perfilhos e de folhas, à atividade da redutase do nitrato, ao valor SPAD, à produção de área foliar e massa seca da planta (parte aérea e raízes), à concentrações de nitrogênio total, de nitrato e de amônio nas folhas emergentes, lâminas de folhas recém-expandidas, lâminas de folhas maduras e raízes. 


\section{REVISÃO DE LITERATURA}

\subsection{Origem e características dos capins Aruana e Marandu}

\subsubsection{Capim-Aruana}

O gênero Panicum caracterizase por possuir grande variabilidade genética e morfofisiológica. É constituído por espécies com hábito de crescimento cespitoso, por plantas tolerantes e sensíveis ao encharcamento, por ecótipos que exigem solos com fertilidade moderada a alta, por plantas tolerantes ou sensíveis ao excesso de alumínio e por possuir reprodução apomítica e sexuada (Corsi, 1988). Tem demonstrado alta produção de massa seca e boa tolerância a pragas e doenças, além de apresentar alto valor nutritivo (Vallejos et al., 1989).

O Panicum maximum Jacq. é uma das espécies de plantas forrageiras mais importantes para a produção de bovinos nas regiões que possuem clima tropical e subtropical (Souza, 1999). No minímo um dos acessos de Panicum maximum Jacq., proveniente da África, foi introduzido no Brasil acidentalmente por volta do século XVIII, por servir de cama para os escravos nas embarcações. Chegando ao Brasil, esta espécie adaptou-se muito bem, principalmente por ter encontrado solos férteis e, inclusive, hoje é considerada nativa em algumas regiões brasileiras (Chase, 1944).

Essa espécie já ocupou áreas superiores a seis milhões de hectares no Brasil (Aronovich, 1995), mas a queda da fertilidade dos solos associada ao manejo inadequado se tornaram os principais fatores limitantes à manutenção do potencial produtivo desta espécie (Corsi \& Santos, 1995).

No Brasil, durante muitos anos o cultivar predominante foi o capim-Colonião, o qual apresenta como uma das suas principais características a pouca adaptabilidade a solos com baixa fertilidade (Jank \& Costa, 1990; Jank, 1994; Aronovich, 1995). 
O capim-Aruana é um cultivar do Panicum maximum que foi introduzido no Instituto de Zootecnia, em Nova Odessa, por intermédio de sementes provenientes da África e trazidas pelo Professor Jorge Ramos Otero. O capim-Aruana tem papel de destaque na Unidade de Ovinos do Instituto de Zootecnia, em Nova Odessa, onde há mais de cinco anos é utilizado no pastejo rotacionado (IZ-2001).

O cultivar Aruana possui como características o porte médio, pode atingir aproximadamente $80 \mathrm{~cm}$ de altura e tem grande potencial e rapidez no perfilhamento, excelente capacidade de cobertura do solo que auxilia no controle da erosão e propagação por sementes que possibilita formação rápida da pastagem. Por se tratar de forragem cespitosa, com crescimento em touceiras, possui uma arquitetura foliar ereta e aberta, propiciando maior área de incidência da radiação solar, alta produtividade de forragem, com 35 a $40 \%$ da produção anual ocorrendo no inverno (quando irrigado), que constitui o período seco do ano. Possui excelente aceitabilidade pelos bovinos, eqüinos e ovinos, e consorcia-se muito bem com leguminosas forrageiras (IZ-2001).

\subsubsection{Capim-Marandu}

A Brachiaria foi descrita pela primeira vez por Trinius em 1834, identificando-a como uma subdivisão do gênero Panicum. Posteriormente, em 1853, foi classificada neste gênero por Grisebach (Renvoize et al., 1996). Ela pertence a um reduzido grupo de gêneros que possuem o ciclo fotossintético $C_{4}$ por fosfoenolpiruvato carboxilase (PEP-Carboxilase), grupo esse formado por Eriochloa, Urochloa e Panicum. O gênero Brachiaria é possuidor de certos limites taxonômicos, prejudicando uma definição relacionada com as espécies componentes, assim como de sua inter-relação com os outros gêneros.

No Brasil, as gramíneas forrageiras do gênero Brachiaria estão ocupando de forma crescente as áreas anteriormente com pastagens nativas, sendo também, os capins deste gênero, os mais plantados no país (Soares Filho, 1994). Estimase que as áreas atualmente formadas por pastagens com braquiárias podem chegar a 60 milhões de hectares (Zimmer et al., 1994).

A Brachiaria brizantha, também conhecida por braquiarão ou brizantão, é uma espécie perene originária de uma região vulcânica da África, onde os solos geralmente 
apresentam bom nível de fertilidade (Bogdan, 1977). É considerada uma espécie cosmopolita em solos vulcânicos no continente africano e apresenta grande diversidade de tipos. Esta planta forrageira é indicada para solos de média a boa fertilidade, tolerando condições de baixa acidez do solo. É descrita como planta cespitosa e muito robusta, tem efetuado boa cobertura do solo, com alta produção de massa verde, alta produção de sementes viáveis e pleno domínio sobre plantas invasoras (Soares Filho, 1994), e alta produção e volume de raízes, que proporcionam maior área ocupada, facilitando a absorção de água e nutrientes (Kanno et al., 1999). Além disso, possui excelente capacidade de rebrota, tolerância ao fogo e apresenta características positivas de suporte à seca e ao frio, permanecendo verde no inverno (Bogdan, 1977). Como atributo negativo, esta espécie tem pouca adaptação a solos mal drenados (Rao, 1996).

O cultivar Marandu foi lançado pela Empresa Brasileira de Pesquisa Agropecuária (Embrapa - CNPGC), tendo como características o porte ereto, podendo chegar a 2,5 m de altura, quando em livre crescimento, lâminas foliares largas e longas e presença de pilosidades nas bainhas, produzindo também intenso perfilhamento (Nunes et al., 1985). Este cultivar é originário do Zimbábue e sua grande representatividade nas pastagens cultivadas está relacionada principalmente à resistência à cigarrinha das pastagens e à excelente resposta quando submetida ao uso de fertilizantes (Soares Filho, 1994). Todas estas qualidades fazem do capimMarandu o grande componente do atual ciclo de pastagens na pecuária brasileira (Aronovich \& Rocha, 1985).

\subsection{Nitrogênio}

\subsubsection{Nitrogênio nas plantas e na adubação de pastagens}

As plantas superiores para terem desenvolvimento normal necessitam de energia solar, água, ar e nutrientes minerais. Com a crescente demanda por maior produtividade vegetal, tem sido aumentada a atenção para uma adequada nutrição das plantas (Monteiro et al., 1997). Os nutrientes minerais presentes nos solos, nas plantas e nos animais desempenham funções vitais para a manutenção de cada componente do sistema solo-planta-animal. $\mathrm{O}$ estabelecimento e a produtividade das plantas 
forrageiras são influenciados pela disponibilidade de nutrientes, principalmente os provenientes do solo (Monteiro \& Werner, 1997).

O que se tem assistido na exploração pecuária brasileira é a utilização das plantas forrageiras de forma extrativista (Monteiro, 1991). Sendo assim, essa pecuária, com características de atividade com natureza extensiva promove diminuição progressiva do valor nutritivo das pastagens, pela retirada contínua de elementos essenciais ao desenvolvimento animal (Serger \& Sanchez, 1996).

A falta de reposição de nitrogênio ou a sua utilização em doses não adequadas em áreas com plantas forrageiras tem sido relacionadas como alguns dos principais fatores responsáveis pela redução da produtividade e pela degradação de pastagens (Corsi \& Martha Júnior, 1997).

O uso de corretivos e fertilizantes é a maneira mais eficiente, mais rápida e mais viável de se aumentar a produtividade das pastagens (Vitti \& Luz, 1997). Esses insumos são imprescindíveis para a nutrição e produção vegetal, contribuindo com pelo menos $40 \%$ da produtividade agrícola (Vitti et al., 1984).

O desenvolvimento de estudos relacionados com a composição mineral das plantas forrageiras tem sido de suma importância para a interpretação de análise foliar, tendo como principal objetivo a orientação de doses de adubos e consequentemente, possíveis interrelações na absorção, translocação e/ou metabolismo desses nutrientes na planta, de forma a aumentar a produtividade de forragem de alta qualidade (Corsi, 1984).

O nitrogênio é um dos mais importantes nutrientes para manutenção da produtividade das gramíneas forrageiras, por ser o principal constituínte das proteínas que participam ativamente na síntese dos compostos orgânicos formadores da estrutura vegetal (Werner, 1986). Também faz parte da composição dos ácidos nucleicos e hormônios, interferindo diretamente no processo fotossintético, por ser constituinte da molécula de clorofila e de uma variedade de outros compostos que influenciam no metabolismo da planta (Hopkins, 1995).

O nitrogênio é responsável por características do porte da planta, tais como tamanho das folhas e do colmo e aparecimento e desenvolvimento dos perfilhos. Com o baixo teor de nitrogênio no solo, o crescimento da planta é lento, apresentando porte pequeno, com poucos perfilhos, e a concentração de proteína não atende as exigências do animal (Werner, 1986). Para Taiz \& Zieger (1991) o nitrogênio é o 
nutriente exigido em maiores quantidades pelas plantas e, segundo Mengel \& Kirkby (2001), a sua concentração na massa seca dos tecidos vegetais pode estar entre 20 e $40 \mathrm{~g} \mathrm{~kg}^{-1}$.

De acordo com Corsi (1984), o nitrogênio promove diversas alterações fisiológicas em gramíneas forrageiras, como no tamanho e na massa seca da planta, taxa de aparecimento de perfilhos e folhas e alongamento do colmo, que são fatores intrínsecos na produção de massa seca e valor nutritivo da planta forrageira.

(Marschner, 1995; Mengel \& Kirkby, 2001) relataram que o nitrogênio é facilmente redistribuído na planta, via floema, de tal forma que os sintomas de deficiência de nitrogênio na planta ocorrem primeiramente nas folhas velhas. Nesta situação, a proteólise e a redistribuição dos aminoácidos resultam no chamado colapso dos cloroplastos, ocasionando o decréscimo no conteúdo de clorofila. Por se tratar de um elemento móvel, a sua baixa concentração na planta causa clorose generalizada nas folhas mais velhas da planta, em consequência da sua translocação para as folhas novas da planta.

As gramíneas forrageiras que fazem parte do grupo C4, respondem muito bem a doses de nitrogênio, apresentando uma alta produção de massa seca, principalmente por possuírem excelente capacidade de aproveitamento da sua área fotossintetizante (Fernandes \& Rossielo, 1986). A utilização do nitrogênio pode ser melhorada conhecendo-se a maneira como este nutriente afeta a produção e a qualidade das plantas forrageiras (Corsi, 1975).

Em estudo desenvolvido com o capim-Colonião (Panicum maximum), Werner et al. (1967) identificaram que a produção de massa seca foi limitada pela não aplicação de adubos contendo nitrogênio. A utilização de adubações, principalmente a nitrogenada, pode melhorar o microclima das plantas forrageiras e, desta maneira, proporcionar a utilização mais eficiente de luz, água e temperatura, que são reconhecidamente, em maior ou menor grau, limitantes ao desenvolvimento das pastagens (Corsi, 1973).

Pastagens de gramíneas forrageiras, quando adubadas com doses de nitrogênio, aumentam linearmente a produção de massa seca e de proteína, até certos limites. De modo geral, as gramíneas tropicais apresentam respostas à adubação nitrogenada até doses de $1800 \mathrm{~kg} \mathrm{ha}^{-1} \mathrm{ano}^{-1}$, embora o uso eficiente seja reduzido a partir da dose de $300 \mathrm{~kg} \mathrm{ha}^{-1}$ ano $^{-1}$ (Malavolta et al., 1974). 
A adubação nitrogenada é responsável pelo maior crescimento relativo da parte aérea que do sistema radicular, segundo relatos de Wilkinson \& Langdale (1974). A explicação para este fato é que, quando o nitrogênio é o fator limitante do crescimento, ocorre na planta um acúmulo de carboidratos, tanto na parte aérea como nas raízes. Como estes carboidratos não podem ser utilizados, nem na formação de novos tecidos nem no crescimento, o nitrogênio absorvido tenderia a reagir com os carboidratos do sistema radicular, beneficiando as raízes em detrimento da parte aérea. A partir do momento em que se aumenta a disponibilidade de nitrogênio, maior proporção desse nutriente é translocado para a parte aérea, possibilitando o uso de carboidratos na síntese de proteínas e no crescimento. Contudo, uma menor proporção de carboidratos é translocada para o sistema radicular, de forma que se justifica o menor crescimento das raízes que o da parte aérea (Brouwer, 1962).

Alvim et al. (1990), ao desenvolverem estudo com a produção de forragem de cinco capins do gênero Brachiaria, que foram submetidos a três doses de nitrogênio ( 0 ; 75 e $150 \mathrm{~kg} \mathrm{ha}^{-1} \mathrm{ano}^{-1}$ ), puderam verificar que houve resposta favorável até a dose de $150 \mathrm{~kg} \mathrm{ha}^{-1} \mathrm{ano}^{-1}$, e que o capim-Marandu foi o que apresentou a maior produção de massa seca, com o emprego da adubação nitrogenada.

Carvalho et al. (1991) constataram que a concentração de nitrogênio na parte aérea da Brachiaria decumbens, cultivada em Latossolo Vermelho-Amarelo com caráter Álico, aumentou linearmente com a aplicação do nitrogênio até a dose de 400 $\mathrm{kg} \mathrm{ha}^{-1}$. Estudando a influência das aplicações de nitrogênio na nutrição mineral e no crescimento de capins do gênero Brachiaria e Panicum, Hoffmann (1992) verificou que a máxima produção da Brachiaria decumbens foi observada na dose de nitrogênio de $437 \mathrm{mg} \mathrm{kg}^{-1}$ de solo.

Monteiro et al. (1995) cultivaram o capim-Marandu em solução nutritiva com omissões de macronutrientes e verificaram que o tratamento com omissão de nitrogênio foi o que mais limitou o desenvolvimento das plantas quanto ao número de perfilhos e altura das plantas e, consequentemente na produção de massa seca da parte aérea e das raízes.

Ao estudarem doses de nitrogênio em solução nutritiva, Santos et al. (1995) observaram que o capim-Vencedor (Panicum maximum) apresentou máxima produção de massa seca com $362 \mathrm{mg} \mathrm{L}^{-1}$ de nitrogênio. Corrêa et al. (1996) relataram que as 
doses de nitrogênio influenciaram no aumento de massa seca e do perfilhamento do capim-Vencedor.

Santos (1997), ao desenvolver estudos relacionados com a diagnose nutricional e respostas da Brachiaria decumbens ao nitrogênio, verificou que a máxima produção de massa seca da parte aérea no primeiro e no segundo crescimentos foi observada nas doses de 435 e $433 \mathrm{mg} \mathrm{L}^{-1}$, respectivamente. De acordo com Ferragine (1998), a produção de massa seca da parte aérea da Brachiaria decumbens mostrou aumento linear até a dose de nitrogênio de $434 \mathrm{mg} \mathrm{L}^{-1}$.

Paulino et al. (1998) avaliaram as doses de nitrogênio de 0, 80 e $160 \mathrm{~kg} \mathrm{ha}^{-1} \mathrm{em}$ quatro cultivares de Panicum maximum (Aruana, Tanzânia, Tobiatã e Vencedor) cultivados em Podzólico Vermelho-Amarelo distrófico, e puderam verificar que o capim-Aruana apresentou excelente produção de massa seca, sendo superado apenas pelo capim-Tanzânia. Também concluíram que as leituras SPAD realizadas em condições de campo podem identificar severas deficiências de nitrogênio em Panicum maximum e que os valores SPAD abaixo de 38 unidades são indicativos de estado nutricional inadequado.

Em estudo desenvolvido por Colozza (2000), com o capim-Aruana cultivado em vasos contendo amostra de Latossolo Vermelho-Amarelo distrófico em condições de casa-de-vegetação e com doses de nitrogênio, foi observada máxima produção de massa seca da parte aérea com as doses nitrogênio de 171 e $332 \mathrm{mg} \mathrm{kg}^{-1}$, no primeiro e segundo ciclos de crescimento, respectivamente. O maior número de perfilhos ocorreu com as doses nitrogênio de 150 e $233 \mathrm{mg} \mathrm{kg}^{-1}$, respectivamente para o primeiro e segundo cortes, enquanto a produção de massa seca de raízes alcançou seu ponto de máximo com o emprego de nitrogênio de $262 \mathrm{mg} \mathrm{kg}^{-1}$.

Manarin (2000) verificou que as doses nitrogênio proporcionaram respostas significativas no incremento da produção de massa seca da parte aérea e das raízes, no número de perfilhos, na área foliar e no total de massa seca da parte aérea e das raízes do capim-Mombaça (Panicum maximum).

Lavres Junior (2001), ao estudar combinações de doses de nitrogênio e de potássio para o capim-Mombaça (Panicum maximum), pôde constatar que o valor máximo de produção de massa seca ocorreu com as doses de nitrogênio de 386 e 412 $\mathrm{mg} \mathrm{L}^{-1}$ para o primeiro e o segundo cortes, respectivamente. Verificou também que a 
máxima produção de massa seca encontrada para as raízes poderia ser obtida com a dose de nitrogênio de $467 \mathrm{mg} \mathrm{L}^{-1}$.

Santos Junior (2001), em estudo desenvolvido com o capim-Marandu submetido a cinco doses de nitrogênio, em função de idades de crescimento, relatou que o aumento na produção de massa seca foi paralelo ao aumento na área foliar, variando segundo modelo quadrático nas doses de nitrogênio de 28 e $112 \mathrm{mg} \mathrm{L}^{-1} \mathrm{e}$ linear nas doses de 210, 294 e $378 \mathrm{mg} \mathrm{L}^{-1}$.

Batista (2002), ao avaliar as respostas do capim-Marandu submetido a combinações de doses de nitrogênio e enxofre, observou que, de acordo com a superfície de resposta, o valor de maior produção de massa seca poderia ocorrer na dose de nitrogênio de $510,8 \mathrm{mg} \mathrm{L}^{-1}$ no primeiro crescimento da planta. No segundo crescimento, a dose de $369,8 \mathrm{mg} \mathrm{L}^{-1}$ foi a que apresentou a máxima produção de massa seca. As doses de nitrogênio de 343 e de $416 \mathrm{mg} \mathrm{L}^{-1}$ foram as responsáveis pelas maiores produções de perfilhos do capim-Marandu no primeiro e no segundo crescimentos, respectivamente.

\subsubsection{Nitrato e amônio nos solos e nas plantas}

$\mathrm{O} \mathrm{N}_{2}$ é a principal forma do nitrogênio na atmosfera, visto que é a fonte natural deste elemento para a biosfera. Porém, o № está na forma gasosa e sendo assim, é muito pequena a proporção aproveitada pelos vegetais. Para que ocorra 0 aproveitamento do $\mathrm{N}$ pelas plantas é necessário que seja transformado em $\mathrm{NH}_{4}^{+} \mathrm{e}$ $\mathrm{NO}_{3}{ }^{-}$

As formas nítrica e amoniacal podem ser absorvidas e metabolizadas pelas plantas (Tisdale et al., 1985). O conhecimento da proporção de nitrato e amônio no sistema de cultivo tem grande importância no que se refere à aquisição de nitrogênio pelas plantas (Mills et al., 1976).

O nitrogênio é absorvido predominantemente pelas raízes nas formas de $\mathrm{NO}_{3}{ }^{-} \mathrm{e}$ $\mathrm{NH}_{4}^{+}$. Normalmente o $\mathrm{NO}_{3}{ }^{-}$é a fonte mais absorvida, porém isto depende da espécie da planta e alguns fatores ambientais devem ser considerados. Entre estes fatores destacam-se o pH, a temperatura e o teor de carboidratos nas raízes (Marschner, 1995 e Mengel \& Kirkby, 2001). 
De acordo com Marschner (1995) a absorção de $\mathrm{NH}_{4}^{+}$é favorecida pelo $\mathrm{pH}$ elevado (meio alcalino), enquanto que absorção de $\mathrm{NO}_{3}{ }^{-}$é favorecida pelo $\mathrm{pH}$ baixo (meio ácido), com valor ótimo em torno de 4,0. Este efeito ocorre devido à competitividade do $\mathrm{H}^{+}$e $\mathrm{OH}^{-}$que são liberados para o meio externo à célula por intermédio de um mecanismo que está associado à atividade das ATPases das membranas no processo de absorção ativa de cátions e ânions.

A absorção do amônio pode resultar em maior quantidade absorvida de formas aniônicas. Em contrapartida, ele promove uma competição com os cátions básicos, de tal forma que a concentração desses cátions acaba sendo mais baixa em plantas dependentes de nitrogênio amoniacal do que nítrico (Adams, 1981). O desbalanço na absorção de cátions ou ânions pode ser promovido pelo emprego de diversas formas nitrogenadas (Tisdale et al., 1985).

A utilização de nitrogênio nítrico possibilita o aumento na absorção de potássio, magnésio e cálcio, compensando a maior absorção de nitrogênio na forma de ânion, visto que o nitrogênio na forma aniônica é a mais absorvida. $O$ aumento na absorção de formas aniônicas é influenciado pela absorção de amônio, mas o amônio também promove um efeito competitivo nos cátions, de modo que a concentração destes cátions vai ser menor em plantas que dependem do nitrogênio amoniacal (Adams, 1981).

Noller \& Rhykerd (1974), ao utilizarem nitrato, observaram que a forragem também apresentou concentrações mais elevadas de cálcio, magnésio e potássio e mais baixas de fósforo e enxofre. A partir do momento em que foi utilizado o nitrogênio como amônio, encontraram concentrações mais elevadas de fósforo e enxofre na massa seca das plantas. O comportamento diferenciado para cada forma empregada é devido ao balanço entre cátions e ânions.

Nas raízes, o nitrogênio absorvido é metabolizado ou pode ser transportado para a parte aérea através do xilema. A forma como o nitrogênio é transportado depende da forma absorvida $\left(\mathrm{NO}_{3}{ }^{-}\right.$ou $\left.\mathrm{NH}_{4}{ }^{+}\right)$e do metabolismo do sistema radicular. Muito do $\mathrm{NH}_{4}^{+}$absorvido é geralmente assimilado no sistema radicular, enquanto 0 $\mathrm{NO}_{3}{ }^{-}$pode ser metabolizado nas raízes ou transportado para a parte aérea (Mengel \& Kirkby, 2001). Após o processo de absorção, $\circ \mathrm{NO}_{3}^{-}$pode ser armazenado nos vacúolos de células das raízes (Hangemam \& Below, 1990; Taiz \& Zieger, 1991). 
O nitrato, uma vez absorvido pelas plantas, é reduzido à forma amoniacal e o nitrogênio é combinado nas cadeias orgânicas do vegetal, formando ácido glutâmico e a partir daí outros aminoácidos. Estudos tem demonstrado que essa assimilação é limitada no processo de redução do nitrato a amônia, processo em que a redutase do nitrato é a enzimachave (Rufty et al., 1986).

Em grande parte das espécies adaptadas a regiões de clima temperado e em condições de baixa concentração de nitrato no solo, a redução do nitrato absorvido se dá nas raízes, enquanto que, em espécies de regiões de clima tropical, a redução do nitrato tende a ocorrer na parte aérea da planta, sem depender da concentração externa deste íon (Nambiar et al., 1988).

A redistribuição do nitrogênio nas plantas, via floema, se dá especialmente na forma de aminoácidos, sendo movimentados das folhas velhas para as novas. Desta forma, o nitrato é praticamente ausente no floema (Mengel \& Kirkby, 2001).

Com relação ao acúmulo de amônio nas plantas, Fernandes \& Rossiello (1985) constataram que em condições ideais ele não é acumulado, mesmo sendo a forma amoniacal tóxica em baixas concentrações. O aumento da concentração de amônio nas plantas pode ocorrer em condições de absorção excessiva ou pela falta de esqueletos carbônicos para a sua incorporação.

Silveira (1981) ressaltou, ao estudar o efeito das proporções de nitrato/ amônio no capim-Colonião cultivado em solução nutritiva, que houve incremento da massa seca àmedida em que se aumentava a concentração de amônio. Para a atividade da redutase do nitrato, as proporções de nitrato/amônio manifestaram acúmulo de nitrato na parte aérea e nas raízes, indicando baixa atividade da enzima da redutase do nitrato, principalmente no sistema radicular.

Andrade (1994) verificou que as plantas que receberam nitrato, combinado ou não com amônio, apresentaram produção de massa seca e concentração de nitrogênio total superiores aos das plantas tratadas apenas com amônio, tanto na parte aérea quanto no sistema radicular, e que a atividade da redutase do nitrato foi estimulada até a proporção de 50/50 de nitrato/amônio.

Abreu (1994), estudando proporções de nitrato/amônio nos capins Gordura (Melinis minutiflora), Marandu (Brachiaria brizantha) e Tanzânia (Panicum maximum), relatou produção de massa seca da parte aérea idênticas para os capins Gordura e Marandu nas proporções 100/0 e 75/25\% em ausência de Ca, enquanto a mesma 
produção não foi encontrada para o capim-Tanzânia, onde ocorreu redução na produção de massa seca com o aumento do $\mathrm{NH}_{4}{ }^{+}$em ausência de Ca. O capimMarandu foi o que mostrou maior produção de massa seca do sistema radicular na proporção 75/25 de nitrato:amônio em ausência de $\mathrm{Ca}$, sendo este resultado mais evidente do que o detectado com os capins Tanzânia e Gordura. Com relação ao estudo da atividade da redutase do nitrato, os capins Marandu e Gordura responderam de forma equivalente em todas as proporções de nitrato/amônio estudadas, porém o capim-Tanzânia foi o que apresentou atividade mais elevada da redutase do nitrato. 


\section{MATERIAL E MÉTODOS}

\subsection{Local e época}

O experimento foi implantado em casa-de-vegetação, localizada no Departamento de Solos e Nutrição de Plantas, da Escola Superior de Agricultura "Luiz de Queiroz"-USP, Campus de Piracicaba, Estado de São Paulo, com o cultivo das plantas forrageiras Panicum maximum cv. Aruana e Brachiaria brizantha cv. Marandu, no período de fevereiro a maio de 2002.

\subsection{Delineamento experimental e tratamentos}

Os vasos foram distribuidos segundo o delineamento estatístico de blocos completos ao acaso, com seis tratamentos (proporções) e quatro repetições. $O$ nitrogênio foi estudado em proporções de nitrato e amônio de 100/0; 85/15; 70/30; 55/45; 40/60 e 25/75\%, respectivamente.

\subsection{Soluções nutritivas}

As soluções nutritivas foram preparadas a partir da solução completa de Sarruge (1975) composta pelos seguintes macronutrientes em $\mathrm{mg} \mathrm{L}^{-1}: \mathrm{N}=210 ; P=31$; $\mathrm{K}=234 ; \mathrm{Ca}=200 ; \mathrm{Mg}=48$ e $\mathrm{S}=64$, devidamente modificada para as proporções desses íons no suprimento de nitrogênio, como apresentado na Tabela 1. 
Tabela 1. Volume e composição química das soluções-estoque empregadas no preparo de um litro das soluções nutritivas para as proporções de nitrato e amônio estudadas

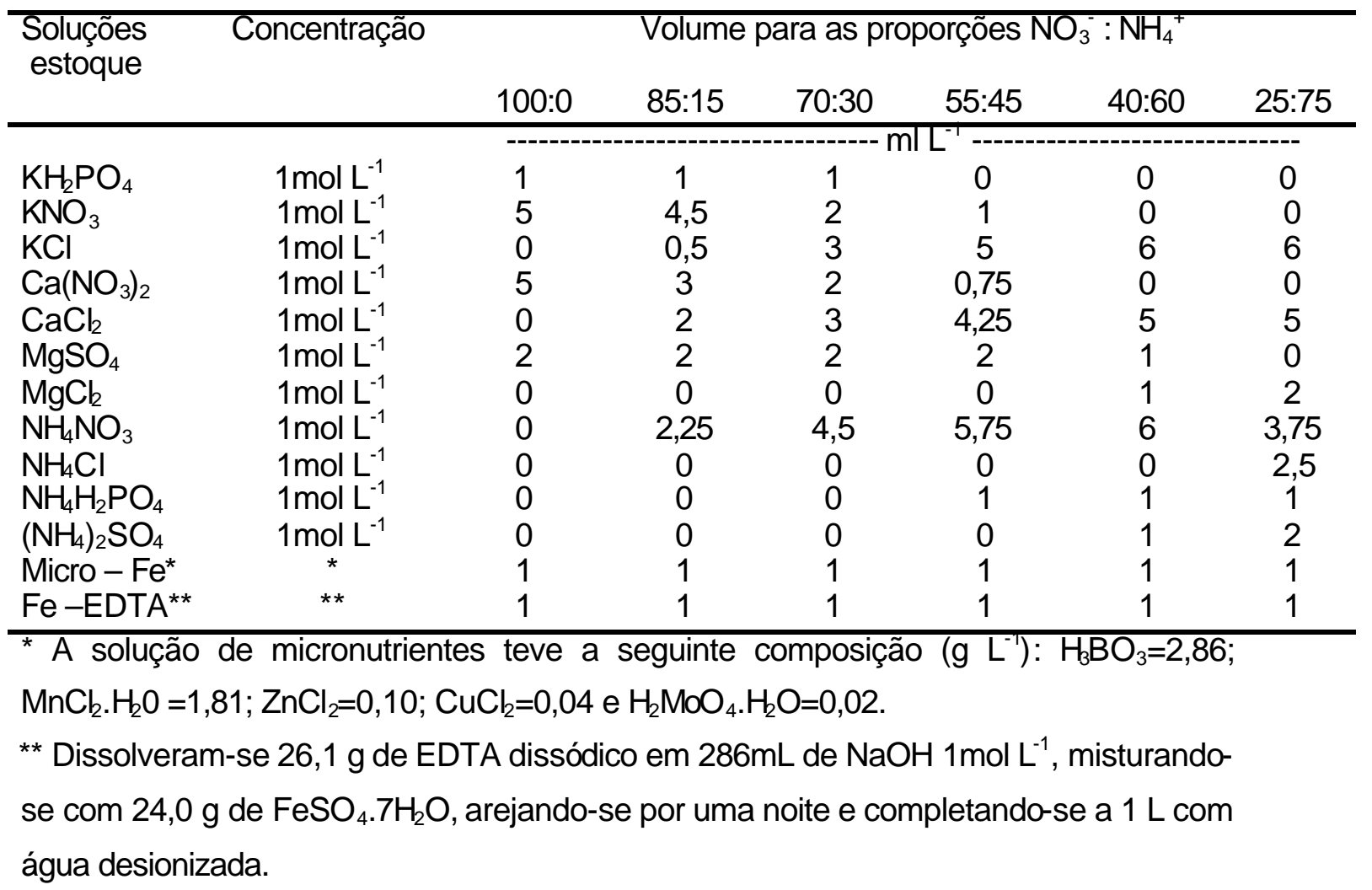

\subsection{Instalação e condução do experimento}

As sementes foram germinadas em bandejas plásticas contendo areia lavada em água corrente e posteriormente em água desionizada. Quando as plântulas alcançaram aproximadamente $5 \mathrm{~cm}$ de altura, transplantaram-se 15 mudas por vaso. Foram utilizados vasos plásticos com capacidade para 3,6 L, contendo sílica como substrato. Logo após o transplante, cada vaso recebeu um litro de solução nutritiva, composta pela concentração definitiva correspondente a cada proporção estudada, que foi circulada através da sílica de cinco a seis vezes por dia e drenada ànoite. Foi realizada a substituição da solução a cada 10 dias e o seu volume foi completado diariamente com água desionizada, assim como a cada três dias procedeu-se o remanejamento na posição dos vasos nas bancadas. 
Foram realizados desbastes periódicos das plantas até a permanência de seis plantas por vaso. Foi realizada a contagem do número de perfilhos e de folhas por vaso no primeiro e no segundo crescimentos.

\subsection{Coleta do material vegetal}

Foram conduzidos dois cortes das plantas. Para o capim-Marandu o primeiro corte se deu aos 37 dias após o transplante das mudas e o segundo aos 33 dias após o primeiro corte. No capim-Aruana, o primeiro corte foi realizado com 28 dias após o transplante e o segundo corte aos 22 dias após o primeiro. A parte aérea da planta foi separada em: a)folhas emergentes: folhas não completamente expandidas, ou seja, sem lígula visível; b)lâminas de folhas recém-expandidas, lâminas das duas folhas mais novas completamente expandidas, com lígula visível; c)lâminas de folhas maduras, lâminas das demais folhas completamente expandidas, com lígula visível; d)colmos mais bainhas das folhas.

Todo o material colhido foi colocado para secar em estufa com circulação forçada de ar, àtemperatura de $65^{\circ} \mathrm{C}$, até atingir massa constante. Posteriormente foi realizada a pesagem, moagem em moinho tipo Willey e armazenamento do material vegetal em sacos plásticos.

\subsection{Determinações no material vegetal}

\subsubsection{Atividade da redutase do nitrato}

A atividade da redutase do nitrato foi determinada aos 20 dias do primeiro e do segundo crescimento das gramíneas forrageiras, utilizando-se o método descrito por Mulder et al. (1959). Os vasos com as plantas foram colocados em câmara-de crescimento e submetidos à exposição de luz artificial por duas horas, de forma a homogeneizar a luminosidade e evitar possíveis interferências de variação na intensidade luminosa na atividade dessa enzima. Coletaram-se amostras do terço médio da lâmina foliar da segunda folha recém-expandida, incubando-se $0,2 \mathrm{~g}$ da amostra cortada do material vegetal em tubos de ensaio contendo $\mathrm{KNO}_{3}$ em tampão 
fosfato, por um período de duas horas. Em seguida, retirou-se 1,0 $\mathrm{mL}$ do material líquido incubado, que serviu para determinação do $\mathrm{NO}_{2}$ pela adição do ácido sulfanílico e $\mathrm{HCl}$ a $20 \mathrm{ml} \mathrm{L}^{-1}$ utilizado com o objetivo de interromper a reação. Após este procedimento, adicionou-se $1,0 \mathrm{~mL}$ de alfanaftilamina, formando a cor rosa ao reagir com o $\mathrm{NO}_{2}$. Foi utilizado o colorímetro a $560 \mathrm{~nm}$ para proceder a leitura das soluções das amostras e para o preparo da reta padrão.

\subsubsection{Estimativa da concentração de clorofila}

Para as medidas indiretas da concentração de clorofila foi utilizado o aparelho Clorophyll Meter SPAD-502 (Soil-Plant Analysis Development Section, Minolta Co. Osaka, Japan). As leituras do clorofilômetro foram realizadas no dia antecedente ao primeiro e segundo cortes das gramíneas forrageiras, no terço médio da lâmina da segunda folha recém-expandida a partir do ápice de cada planta (Santos, 1997). Foram realizadas cinco leituras em cada vaso, a partir das quais foram obtidas as médias referentes a cada unidade experimental.

\subsection{3 Área foliar}

A área foliar foi medida nos tecidos foliares coletados na parte aérea (folhas emergentes, lâminas de folhas recém-expandidas e lâminas de folhas maduras), na ocasião do primeiro e do segundo corte das plantas, utilizando-se o aparelho integrador de área foliar.

\subsubsection{Produção de massa seca}

Após a secagem do material vegetal, foi procedida a pesagem de cada componente da parte aérea e de raízes, obtendo-se a massa seca de cada componente e do total da parte aérea. 


\subsubsection{Concentração de nitrogênio total}

Foi realizada a determinação da concentração de $\mathrm{N}$ total em cada componente da parte aérea e nas raízes, de acordo com o método descrito por Sarruge \& Haag (1974), com destilação em aparelho semi-micro Kjeldahl e a titulação com ácido sulfúrico a $0,02 \mathrm{~mol} \mathrm{~L}^{-1}$.

\subsubsection{Concentração de nitrogênio nas formas de amônio e nitrato}

A determinação da concentração de amônio foi realizada como descrito por Tedesco et al. (1985) e ocorreu com o uso de $0,1 \mathrm{~g}$ do material seco das diversas partes da parte aérea e das raízes, de cada tratamento, com destilação após adição de $0,2 \mathrm{~g}$ de $\mathrm{MgO}$ calcinado. Em seguida, foram obtidas as frações de $\mathrm{NH}_{4}{ }^{+}$por intermédio da titulação com ácido sulfúrico a $0,001 \mathrm{~mol} \mathrm{~L}^{-1}$, após serem recolhidas em indicadores com ácido bórico. Logo após foi determinado o $\mathrm{NO}_{3}{ }^{-}$, utilizando-se o mesmo tubo empregado para destilação do $\mathrm{NH}_{4}{ }^{+}$, adicionando-se $0,2 \mathrm{~g}$ de Liga de Devarda e encaminhado para nova destilação e posterior titulação com o mesmo ácido utilizado para o amônio.

\subsubsection{Sistema radicular}

Ao final do segundo crescimento, o sistema radicular foi separado da sílica mediante lavagem com água corrente sobre um conjunto de peneiras com malhas de 1,00 e 0,25 mm. Posteriormente foram retiradas sub-amostras das raízes cortando-as na forma vertical e na horizontal, de forma a se obter aproximadamente $20 \%$ do total de massa fresca, de acordo com o método apresentado por Rossiello et al. (1995). Essas sub-amostras foram colocadas em copos plásticos e saturadas com a mistura de água desionizada e corante (violeta genciana), com o intuito de tingir as raízes. Após o período de tingimento, as raízes foram secadas e espalhadas na superfície de uma transparência, tomando-se o cuidado em não sobrepô-las. Em seguida foram colocadas em "scanner", para transformação em imagens digitalizadas e posterior análise com o uso do aplicativo SIARCS-Sistema Integrado para Análise de Raízes e Cobertura do Solo, como realizado por (Crestana et al., 1994). Através dessa análise 
foi obtido o valor do comprimento e da superfície radicular, bem como foi calculado o valor do comprimento radicular específico pela razão entre o comprimento e a massa seca das raízes.

\subsection{Análise estatística}

Os resultados foram submetidos àanálise de variância através do procedimento GLM, utilizando o aplicativo SAS (SAS-Institute, 1989), para estudar o efeito das proporções de nitrato e amônio nos atributos avaliados, com o emprego do teste de Tukey $(\mathrm{P}<0,05)$ para comparação das médias. 


\section{RESULTADOS E DISCUSSÃO}

\subsection{Número de perfilhos}

A análise de variância demonstrou respostas significativas $(P<0,01)$ para as proporções de nitrato e amônio no número de perfilhos por vaso do capim-Aruana, no primeiro e segundo crescimentos. No primeiro crescimento as proporções de 100/0, 85/15, 70/30, 55/45 e 40/60 foram semelhantes entre si e apresentaram maior número de perfilhos (Figura 1), enquanto que no segundo crescimento as proporções que tiveram maior número de perfilhos foram as de 70/30 e 55/45 (Figura 2). É importante salientar que a proporção $25 / 75$ de nitrato/amônio foi a única que diferiu estatisticamente das demais proporções, em ambos os cortes, e a que mostrou praticamente ausência de perfilhamento do capim.

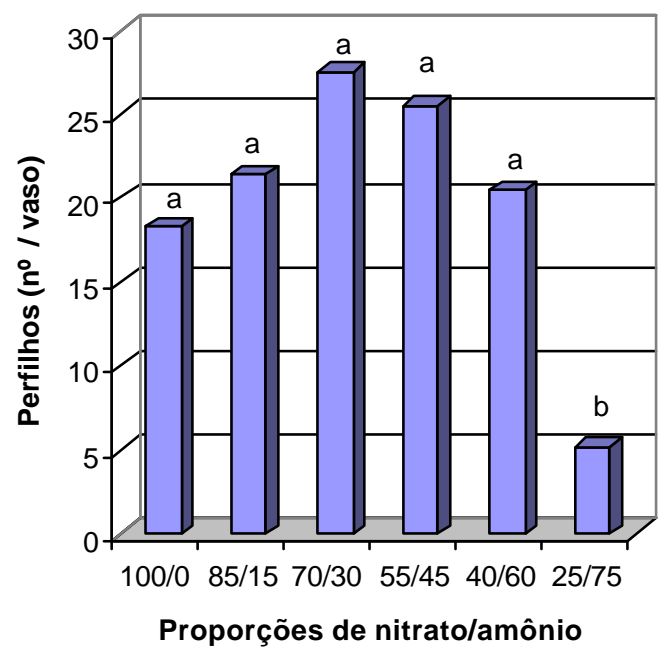

Figura 1 - Número de perfilhos por vaso do capim-Aruana, no primeiro crescimento, em função das proporções de nitrato e amônio na solução nutritiva. Letras diferentes indicam diferença entre médias pelo teste de Tukey $(P<0,05)$ 
Abreu (1994) também observou respostas significativas $(P<0,01)$ no perfilhamento dos capins Gordura, Marandu e Tanzânia, para as proporções de nitrato e amônio. Entretanto a proporção de 75/25 (-Ca) foi a que apresentou maior número perfilhos no capim-Tanzânia.

Corrêa (1996), estudando as respostas dos capins Colonião, Tanzânia-1 e Vencedor, æ̀ aplicações de nitrogênio e magnésio em solução nutritiva, ressaltou que o nitrogênio fornecido até concentração de $210 \mathrm{mg} \mathrm{L}^{-1}$ compostas pelas proporções de 100 de nitrato e 76/24 de nitrato/amônio, influenciaram positivamente a produção de perfilhos. Colozza et al. (2000) observou que o maior número de perfilhos do capimAruana no segundo crescimento, ocorreu quando a aplicação de $210 \mathrm{mg} \mathrm{kg}^{-1}$ de nitrogênio na forma de nitrato de amônio, estabelecida pela proporção 50/50 de nitrato/amônio.

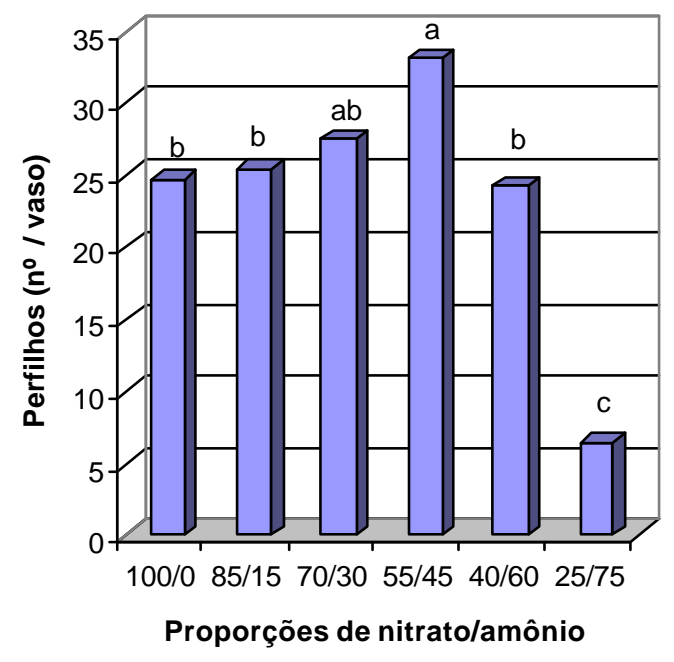

Figura 2 - Número de perfilhos por vaso do capim-Aruana, no segundo crescimento, em função das proporções de nitrato e amônio na solução nutritiva. Letras diferentes indicam diferença entre médias pelo teste de Tukey $(P<0,05)$

O número de perfilhos do capim-Marandu no primeiro e segundo corte, variou significativamente $(\mathrm{P}<0,01)$ com as proporções de nitrato/amônio, revelando as proporções de 85/15, 70/30, 55/45 e 40/60 com maiores produções de perfilhos, porém sem diferir estatísticamente entre si (Figuras 3 e 4). 


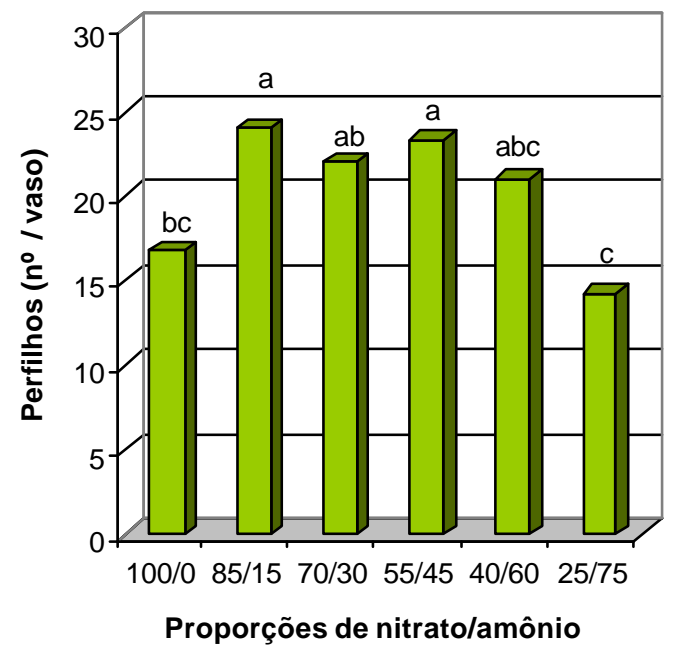

Figura 3 - Número de perfilhos por vaso do capim-Marandu, no primeiro crescimento, em função das proporções de nitrato e amônio na solução nutritiva. Letras diferentes indicam diferença entre médias pelo teste de Tukey $(P<0,05)$

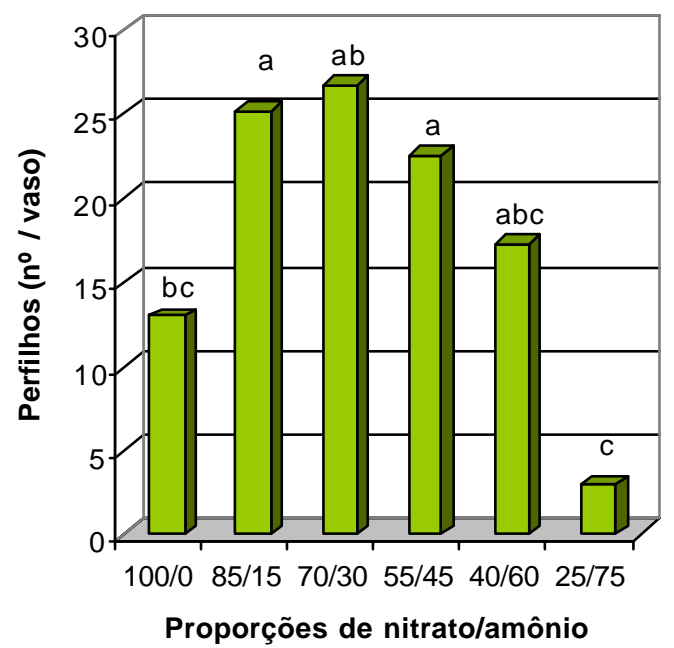

Figura 4 - Número de perfilhos por vaso do capim-Marandu, no segundo crescimento, em função das proporções de nitrato e amônio na solução nutritiva. Letras diferentes indicam diferença entre médias pelo teste de Tukey $(P<0,05)$ 
Santos Junior (2001) constatou que o nitrogênio fornecido em solução nutritiva na dose de $210 \mathrm{mg} \mathrm{L}^{-1}$ que corresponde a proporção 70/30 de nitrato/amônio, alterou significativamente o perfilhamento do capim-Marandu, dentro de cada idade de crescimento. O mesmo resultado foi obtido por Batista (2002) destacando que o número total de perfilhos por vaso também apresentou comportamento diferenciado entre o primeiro e o segundo crescimentos do capim-Marandu, verificando respostas significativas $(P<0,01)$ para o nitrogênio empregado na solução nutritiva na dose de $210 \mathrm{mg} \mathrm{L}^{-1}$ também formada por 70/30 \% de nitrato/amônio.

\subsection{Número de folhas}

O número total de folhas por vaso do capim-Aruana na ocasião do primeiro e segundo cortes mostrou respostas significativas $(P<0,01)$ æ̀ proporções de nitrato e amônio. As proporções de 70/30 e 55/45 de nitrato/amônio foram as que resultaram mais altos números totais de folhas por vaso, enquanto a proporção 25/75 mostrou o menor número de folhas, quando comparada com as demais proporções no primeiro corte (Figura 5). No segundo corte, os maiores números de folhas foram encontrados nas proporções 100/0, 85/15, 70/30 e 55/45 de nitrato/ amônio (Figura 6).

Lavres Junior (2001) constatou que a produção de folhas variou significativamente $(P<0,01)$ para o estudo do nitrogênio na dose de $210 \mathrm{mg} \mathrm{L}^{-1}$ composta por 64,4/35,6 de nitrato/amônio. Verificou também que o nitrogênio fornecido na concentração de $210 \mathrm{mg} \mathrm{L}^{-1}$ solução nutritiva completa de Sarruge (1975) não é suficiente para atender as exigências do capim-Mombaça para o seu potencial máximo de produção de folhas no primeiro e segundo cortes.

A análise de variância do número total de folhas por vaso do capim-Marandu no primeiro e segundo cortes, revelou resultados significativos $(P<0,01)$ para as proporções de nitrato/amônio. As plantas que receberam as proporções 85/15, 70/30 e $55 / 45$ no primeiro crescimento e $70 / 30$ e $55 / 45$ no segundo período foram as que apresentaram maior número total de folhas por vaso. A proporção com mais elevada concentração de amônio (25/75) foi a que diferenciou-se estatisticamente das demais (excecão da proporção 100/0 no primeiro crescimento) e apresentou menor produção de folhas por vaso (Figuras 7 e 8). 


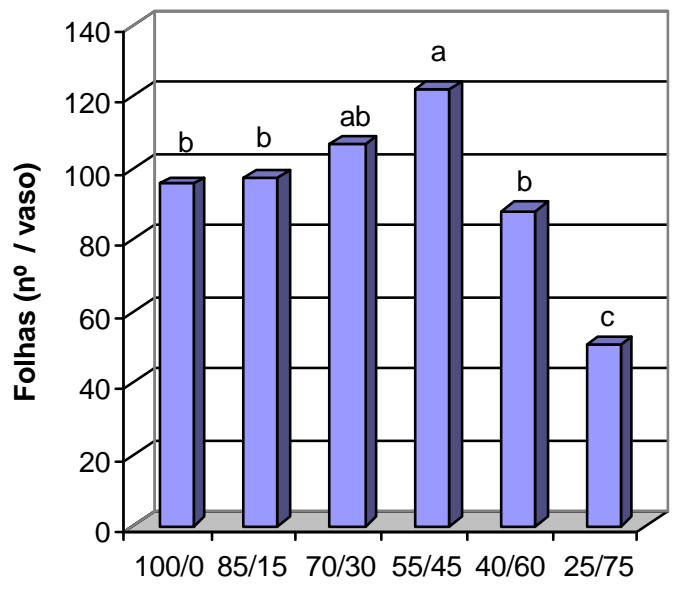

Proporções de nitrato/amônio

Figura 5 - Número total de folhas por vaso do capim-Aruana, no primeiro corte, em função das proporções de nitrato e amônio na solução nutritiva. Letras diferentes indicam diferença entre médias pelo teste de Tukey $(P<0,05)$

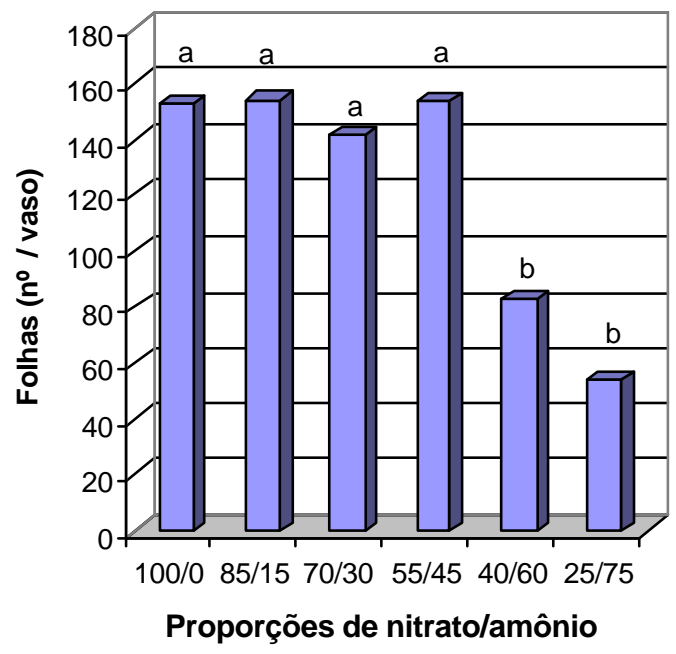

Figura 6 - Número total de folhas por vaso do capim-Aruana, no segundo corte, em função das proporções de nitrato e amônio na solução nutritiva. Letras diferentes indicam diferença entre médias pelo teste de Tukey $(P<0,05)$ 


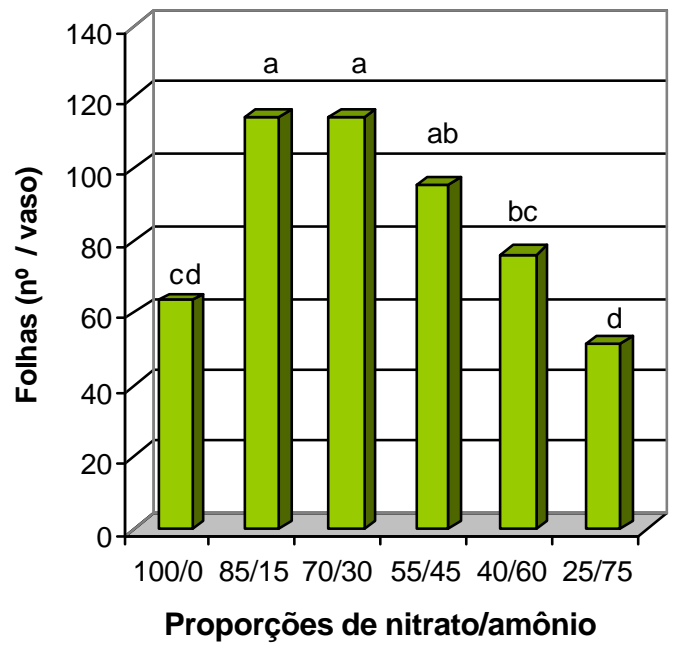

Figura 7 - Número total de folhas por vaso do capim-Marandu, no primeiro corte, em função das proporções de nitrato e amônio na solução nutritiva. Letras diferentes indicam diferença entre médias pelo teste de Tukey $(P<0,05)$

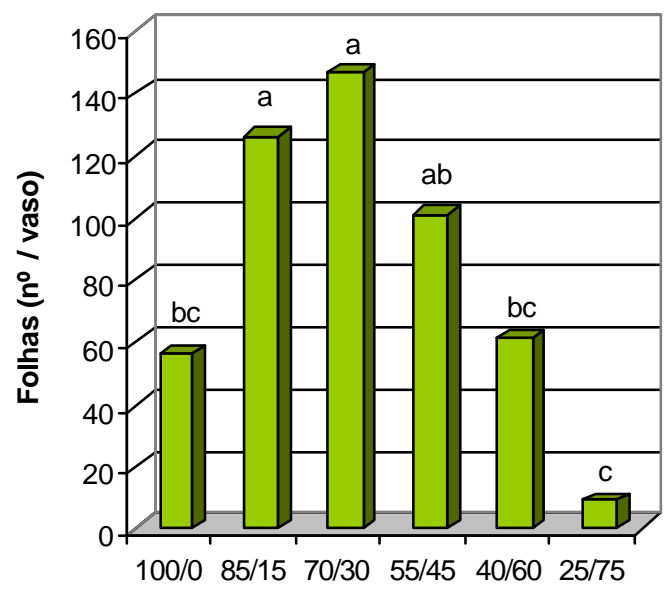

Proporções de nitrato/amônio

Figura 8 - Número total de folhas por vaso do capim-Marandu, no segundo corte, em função das proporções de nitrato e amônio na solução nutritiva. Letras diferentes indicam diferença entre médias pelo teste de Tukey $(P<0,05)$ 
Schiavuzzo et al. (2000), estudando a Brachiaria brizantha cv. Marandu submetida ao nitrogênio, constatou que a produção de folhas verdes expandidas por vaso, na ocasião do primeiro corte, sofreu influência significativa $(P<0,05)$ do fornecimento de nitrogênio na solução nutritiva. Batista (2002) obteve maior produção do número de folhas por vaso do capim-Marandu na ocasião do primeiro crescimento quando a dose de nitrogênio foi superior a $210 \mathrm{mg} \mathrm{L}^{-1}$ e a proporção de nitrato/amônio era de $70 / 30$.

\subsection{Estimativa do teor de clorofila através de unidades SPAD}

Os resultados das leituras de clorofila pelo Chlorophyll Meter SPAD nas lâminas de folhas recém-expandidas demonstraram significância $(P<0,01)$ para as proporções de nitrato/amônio fornecidas em solução nutritiva, tanto no primeiro como no segundo crescimento do capim-Aruana (Figuras 9 e 10). O mais elevado valor SPAD obtido no primeiro crescimento do capim-Aruana foi de 36,9 e no segundo crescimento de 38,8 unidades.

Lavres Junior (2001) constatou que, no primeiro crescimento, o valor SPAD do capim-Mombaça na concentração de $210 \mathrm{mg} \mathrm{L}^{-1}$ obteve valor médio correspondente à $75,36 \%$ do valor SPAD obtido na concentração mais alta de nitrogênio empregada no estudo, quando fixou a proporção nitrato/amônio em 64,4/35,6.

Foi constatado que os valores SPAD no segundo crescimento do capimAruana, apresentaram resultados em geral superiores ao do primeiro crescimento. Este fato pode ser demonstrado pela relação direta do teor de clorofila com as proporções de nitrato e amônio.

Manarin (2000), trabalhando com nitrogênio no capim-Mombaça, obteve valores entre 41 e 45 unidades de valor SPAD nas folhas recém-expandidas, no segundo crescimento. Lavres Junior (2001) constatou que, no segundo crescimento do capimMombaça, o valor médio SPAD correspondeu a 75,36\% na dose de $210 \mathrm{mg} \mathrm{L}^{-1}$ corresponde a 64,4/35,6 \% de nitrato/amônio foi de 20,5 e 39,0 unidades SPAD para as doses de nitrogênio na solução empregada 28 e de $462 \mathrm{mg} \mathrm{L}^{-1}$, respectivamente. Obsevou que à medida em que se aumentava a dose de nitrogênio na solução nutritiva, ocorria um maior valor SPAD na planta, comprovando a relação nitrogênio/clorofila. 


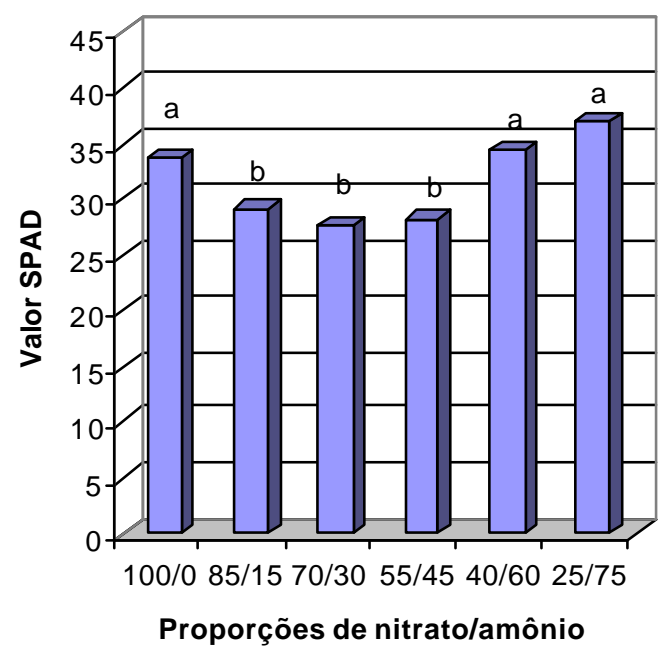

Figura 9 - Valor SPAD do capim-Aruana, no primeiro crescimento, em função das proporções de nitrato e amônio na solução nutritiva. Letras diferentes indicam diferença entre médias pelo teste de Tukey $(P<0,05)$

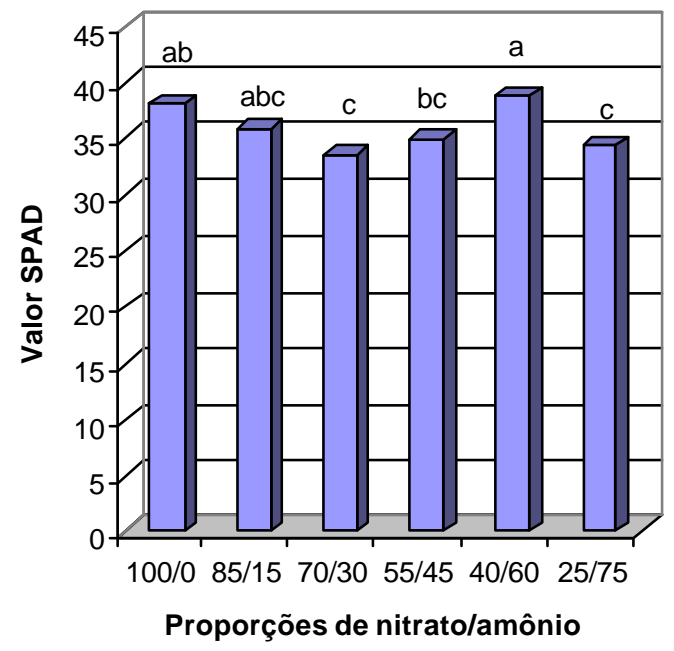

Figura 10 - Valor SPAD do capim-Aruana, no segundo crescimento, em função das proporções de nitrato e amônio na solução nutritiva. Letras diferentes indicam diferença entre médias pelo teste de Tukey $(P<0,05)$ 
A análise de variância do valor SPAD no primeiro crescimento do capimMarandu não apresentou significância $(P>0,05)$ para as proporções de nitrato/amônio. Entretanto, na ocasião do segundo crescimento do capim-Marandu ocorreu significância $(\mathrm{P}<0,01)$ para as proporções de nitrato/amônio, quanto ao valor SPAD. Os valores demonstram que as proporções 100/0, 85/15 e 40/60 foram as que resultaram em valores mais elevados que as demais proporções (Figura 11).

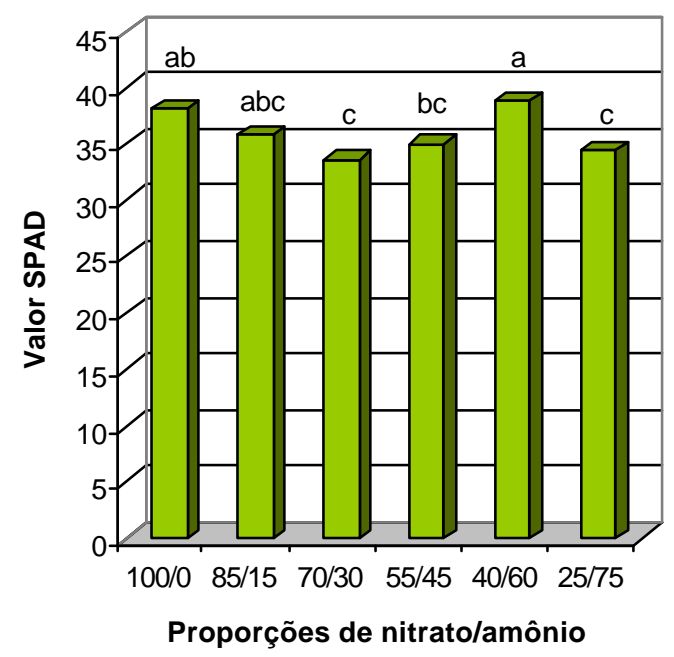

Figura 11 - Valor SPAD do capim-Marandu, no segundo crescimento, em função das proporções de nitrato e amônio na solução nutritiva. Letras diferentes indicam diferença entre médias pelo teste de Tukey $(P<0,05)$

Santos (1997) observou que os valores SPAD para a Brachiaria decumbens foram de 17,0 e 50,2 e 23,9 e 52,0 para a condição de omissão e aplicação de nitrogênio em doses superiores a $210 \mathrm{mg} \mathrm{L}^{-1}, 100 \%$ de nitrato, para o máximo valor SPAD, as quais corresponderam æ̀ doses de nitrogênio de 330 e $442 \mathrm{mg} \mathrm{L}^{-1}$, no primeiro e segundo crescimentos, respectivamente. Colozza (1998) constatou valores críticos de nitrogênio variando entre 32,0 e 38,6 unidades SPAD para o capimMombaça.

Abreu \& Monteiro (1999), em estudo com o capim-Marandu em função de adubação nitrogenada com nitrato de amônio (50/50 \%) e estádios de crescimento, relataram que para as idades de 28 e 42 dias do crescimento inicial, o máximo valor 
SPAD ocorreu nas doses de 205,0 e $314,5 \mathrm{mg} \mathrm{kg}^{-1}$, e variou entre 32 e 45 e 18 e 38 para a não-aplicação de nitrogênio e para o máximo valor SPAD.

\subsection{Atividade da redutase do nitrato}

A atividade da enzima redutase do nitrato apresentou variação significativa $(P<0,01)$, com as proporções de nitrato/amônio e foi estimulada pelo incremento de amônio nas proporções de nitrato/amônio, no período do primeiro crescimento (Figura 12).

Andrade (1994) observou que a atividade da redutase do nitrato aumentou com o incremento do amônio na proporção de nitrato/amônio até atingir a maior atividade na proporção de 50/50. em proporções com mais alta participação do amônio a atividade enzimática diminuiu, o que difere do obtido no presente experimento.

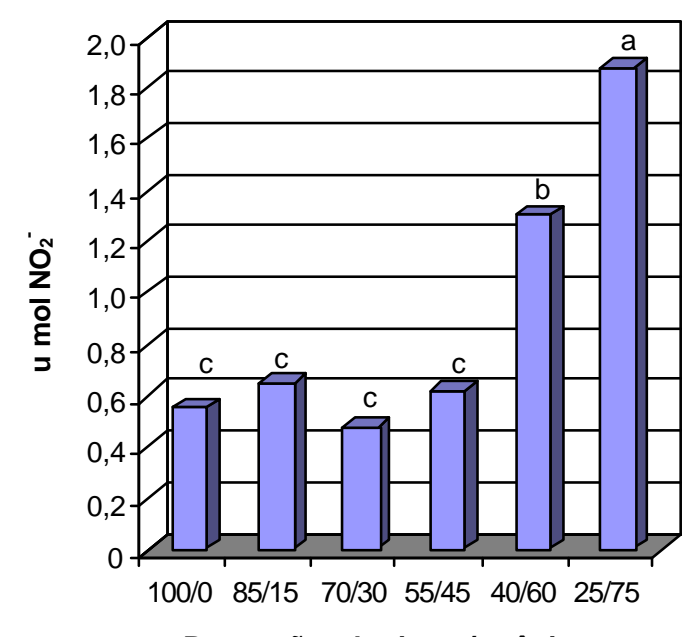

Proporções de nitrato/amônio

Figura 12 - Atividade da redutase do nitrato no capim-Aruana, na ocasião do primeiro crescimento, em função das proporções de nitrato e amônio na solução nutritiva. Letras diferentes indicam diferença entre médias pelo teste de Tukey $(P<0,05)$

Abreu (1994) constatou que a atividade da redutase do nitrato no capimTanzânia apresentou resultados similares nas proporções de nitrato/amônio de 100/0 e 75/25 (com ou sem cálcio), enquanto a atividade dessa enzima nas proporções 50/50 e 
25/75 foi significativamente $(P<0,05)$ inferior ao da proporção 75/25 (sem cálcio). Os capins Gordura e Marandu também apresentaram resultados semelhantes, dentro de todas as proporções de nitrato/amônio fornecidas na solução nutritiva.

Santos (1997) observou atividade máxima da enzima da redutase do nitrato, sendo esta atividade mais elevada do que a encontrada por Abreu (1994), ao fornecer nitrogênio na concentração de $210 \mathrm{mg} \mathrm{L}^{-1}$ com $100 \%$ de nitrato, em solução nutritiva para a Brachiaria decumbens. Lavres Junior (2001) destacou, em estudo com o capimMombaça, que nas doses de nitrogênio mais elevadas que $210 \mathrm{mg} \mathrm{L}^{-1}$ composta pela proporção 64,4/35,6 de nitrato/amônio, obteve mais altas atividades da enzima redutase do nitrato, no primeiro crescimento.

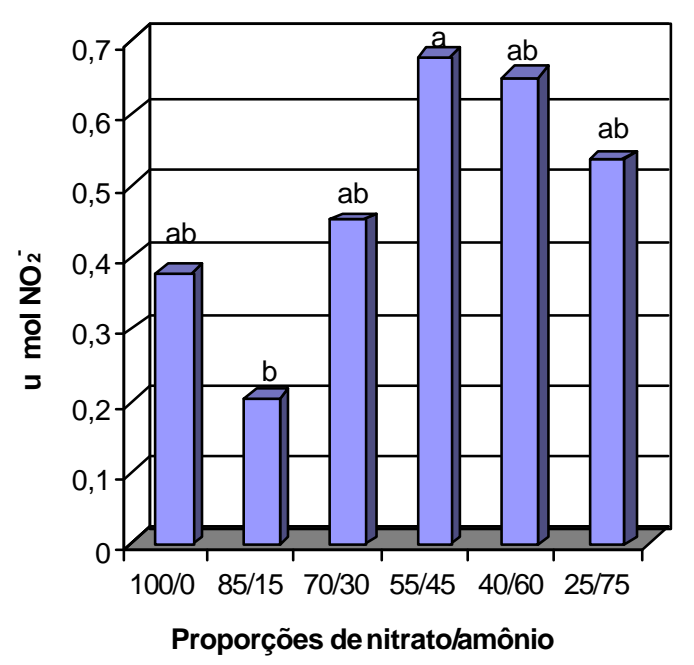

Figura 13 - Atividade da redutase do nitrato no capim-Aruana, na ocasião do segundo crescimento, em função das proporções de nitrato e amônio na solução nutritiva. Letras diferentes indicam diferença entre médias pelo teste de Tukey $(P<0,05)$

A atividade da redutase do nitrato no capim-Aruana quando do segundo crescimento apresentou variação significativa $(P<0,05)$ para as proporções de nitrato e amônio. Através da comparação de médias, foi possível constatar que as proporções 100/0, 70/30, 55/45, 40/60 e 25/75 apresentaram mais elevadas atividades da enzima, porém sem diferir estatisticamente entre si (Figura 13). Para o capim-Marandu, a 
atividade da redutase do nitrato não apresentou significância $(P>0,05)$ para as proporções de nitrato e amônio em ambos os crescimentos.

\section{5 Área foliar total}

A área foliar total por vaso do capim-Aruana variou significativamente $(P<0,01)$, nas ocasiões do primeiro e segundo cortes, com as proporções de nitrato/amônio fornecidas na solução nutritiva. Na ocasião do primeiro corte, a comparação de médias demonstrou que as proporções de nitrato/amônio que tinham maiores concentrações de amônio (40/60 e 25/75) foram as que apresentaram menor área foliar, e que diferenciaram-se estatisticamente das demais proporções (Figura 14). O valor absoluto de área foliar total produzida no segundo crescimento da planta foi superior ao primeiro e a máxima área foliar obtida foi de $71,5 \%$ maior no segundo crescimento.

O nitrogênio fornecido em proporções de nitrato e amônio, na ocasião do segundo corte, apresentou maior área foliar nas proporções de 85/15, 70/30 e 55/45, não diferindo estatisticamente entre si. Como visto no primeiro corte a proporção 25/75 apresentou diferença significativa em relação as outras proporções, como pode ser verificado na figura 15.

Manarin (2000) constatou que a área foliar do capim-Mombaça foi influenciada pelo nitrogênio fornecido em solução nutritiva. No primeiro corte, foram necessárias doses de nitrogênio superiores a $210 \mathrm{mg} \mathrm{L}^{-1}$ que foi fornecida com $100 \%$ de nitrato, para que obtivesse produção da máxima área foliar das folhas recém-expandidas.

Lavres Junior (2001) observou que, para o segundo crescimento do capimMombaça, a concentração de nitrogênio de $210 \mathrm{mg} \mathrm{L}^{-1}$ respeitando a proporção de 64,4/35,6 de nitrato/amônio na solução nutritiva, não seria suficiente para produção da máxima área foliar, que seria obtida na concentração de $477 \mathrm{mg} \mathrm{L}^{-1}$, evidenciando o potencial produtivo desse capim, sob condições de elevado fornecimento de nitrogênio. Constatou também, ao comparar os dois períodos de crescimento, que o valor absoluto de área foliar total produzida no segundo crescimento foi $68 \%$ superior ao valor da máxima área foliar obtida no primeiro crescimento. 


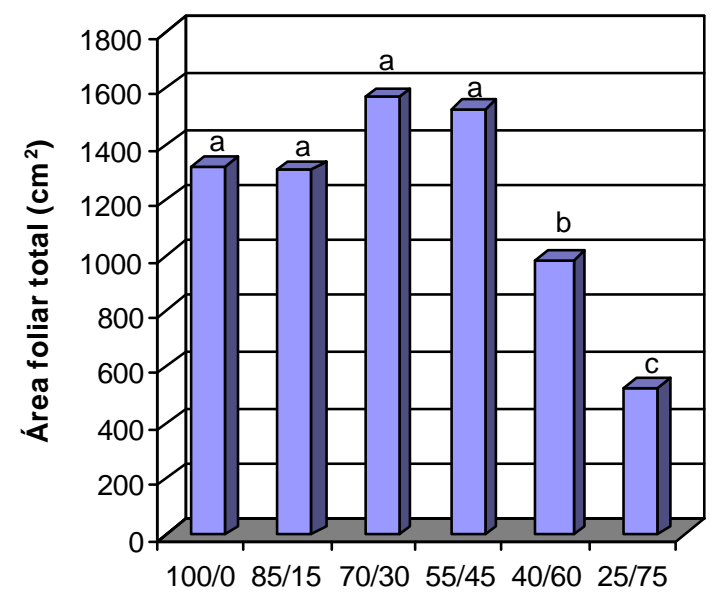

Proporções de nitrato/amônio

Figura 14 - Área foliar total àépoca do primeiro corte do capim-Aruana, em função das proporções de nitrato e amônio na solução nutritiva. Letras diferentes indicam diferença entre médias pelo teste de Tukey $(P<0,05)$

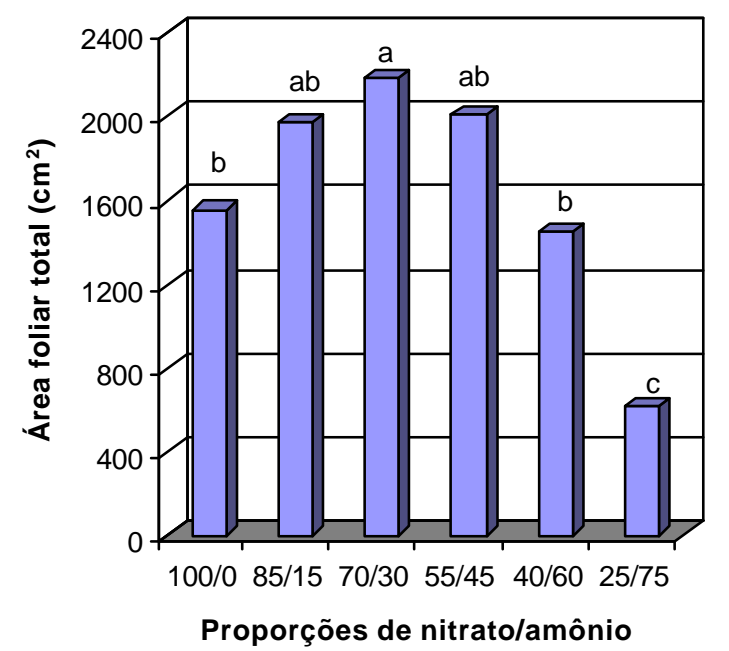

Figura 15 - Área foliar total à época do segundo corte do capim-Aruana, em função das proporções de nitrato e amônio na solução nutritiva. Letras diferentes indicam diferença entre médias pelo teste de Tukey $(P<0,05)$ 


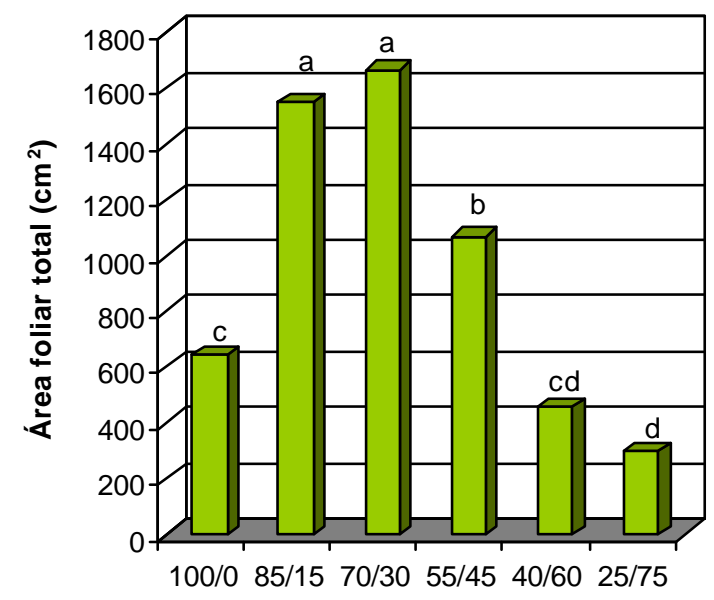

Proporções de nitrato/amônio

Figura 16 - Área foliar total àépoca do primeiro corte do capim-Marandu, em função das proporções de nitrato e amônio na solução nutritiva. Letras diferentes indicam diferença entre médias pelo teste de Tukey $(P<0,05)$

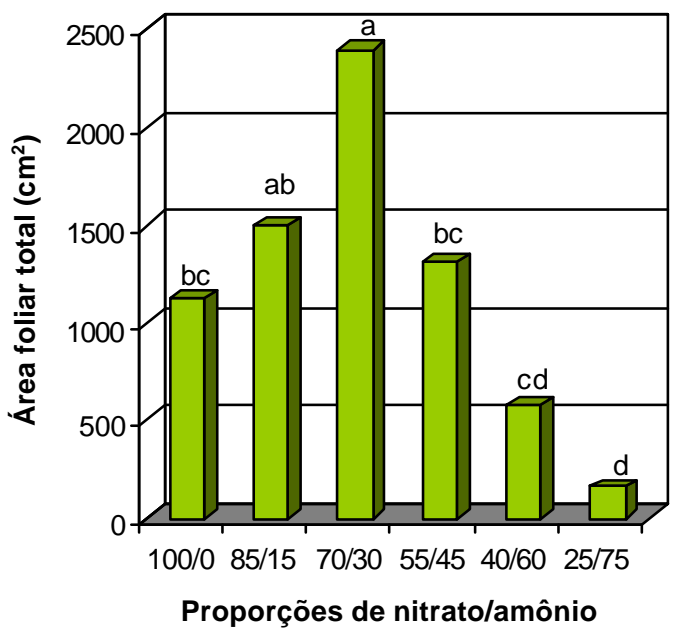

Figura 17 - Área foliar total àépoca do segundo corte do capim-Marandu, em função das proporções de nitrato e amônio na solução nutritiva. Letras diferentes indicam diferença entre médias pelo teste de Tukey $(P<0,05)$ 
A análise de variância para os resultados de área foliar do capim-Marandu, correspondente ao primeiro e segundo crescimentos, demonstrou significância $(\mathrm{P}<0,01)$ para as proporções de nitrato e amônio. No primeiro e segundo crescimentos a comparação de médias apresentou maior área foliar nas proporções de 85/15 e 70/30 de nitrato/amônio (Figuras 16 e 17). Comparando-se os dois períodos, o máximo valor total de área foliar produzido pela planta no segundo corte, foi $69,4 \%$ maior que no primeiro.

Batista (2002) observou que para o capim-Marandu na ocasião do segundo crescimento, o nitrogênio na solução em $210 \mathrm{mg} \mathrm{L}^{-1}$ (70/30 \% de nitrato/amônio), não foi suficiente para obter a maior área foliar total da planta, resultado esse obtido na dose de 381,6 $\mathrm{mg} \mathrm{L}^{-1}$. Quando comparou os dois períodos de crescimento, constatou que a máxima área foliar do segundo corte foi $50,9 \%$ superior ao valor obtido no primeiro corte, resultado esse inferior ao encontrado por Lavres Junior (2001).

\subsection{Produção de massa seca da planta}

\subsubsection{Produção de massa seca da parte aérea da planta}

A análise de variância para a produção de massa seca da parte aérea do capim-Aruana, correspondente ao primeiro crescimento, mostrou significância $(P<0,01)$ para as proporções de nitrato e amônio na solução nutritiva.

De acordo com a comparação de médias, as maiores produção de massa seca, no primeiro crescimento do capim-Aruana, ocorreram com as proporções 100/0, 85/15, 70/30 e 55/45 de nitrato/amônio (Figura 18). Resultados encontrados por Abreu (1994) com as proporções de nitrato/amônio não foram significativos para o capim-Tanzânia. E este capim reduziu a produção de massa seca com o aumento da proporção de amônio, associado àausência de cálcio.

Andrade (1994) obteve, para o capim-Colonião submetido a proporções de nitrato e amônio, aumento da produção de massa seca com os tratamentos que continham maior concentração de nitrato quando comparados com os que receberam apenas amônio.

Para a produção de massa seca da parte aérea no segundo corte do capimAruana, observaram-se respostas significativas $(P<0,01)$ às proporções de nitrato $e$ 
amônio. Os resultados demonstraram que as proporções de 100/0, 85/15, 70/30 e $55 / 45$ não diferiram entre si, porém produziram mais massa seca da parte aérea do que a proporção 25/75 (Figura 19).

Colozza (2000), cultivando o capim-Aruana em vasos contendo amostra de Latossolo Vermelho-Amarelo distrófico, observou que a máxima produção de massa seca da parte aérea foi encontrada com a aplicação de nitrogênio de 171 e $332 \mathrm{mg} \mathrm{kg}^{-1}$ na forma de nitrato de amônio (50/50 \% de nitrato/amônio), no primeiro e segundo ciclos de crescimento da planta.

Lavres Junior (2001), constatou que o valor máximo de produção de massa seca ocorreu com emprego de nitrogênio em dose superior a $210 \mathrm{mg} \mathrm{L}^{-1}$, satisfeita pela proporção de 64,4/35,6 de nitrato/amônio na solução nutritiva, para o capim-Mombaça, no primeiro e o segundo cortes, respectivamente.

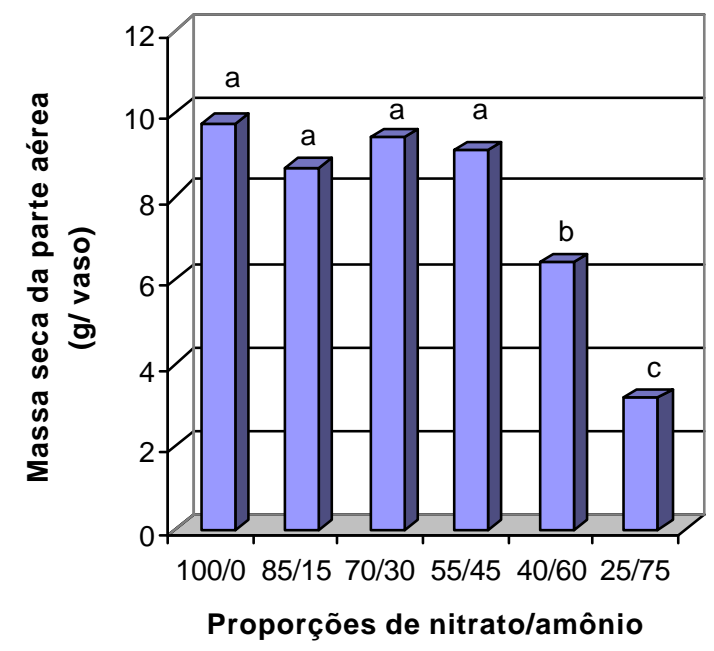

Figura 18 - Produção de massa seca da parte aérea do capim-Aruana, no primeiro corte, em função das proporções de nitrato e amônio na solução nutritiva. Letras diferentes indicam diferença entre médias pelo teste de Tukey $(\mathrm{P}<0,05)$ 


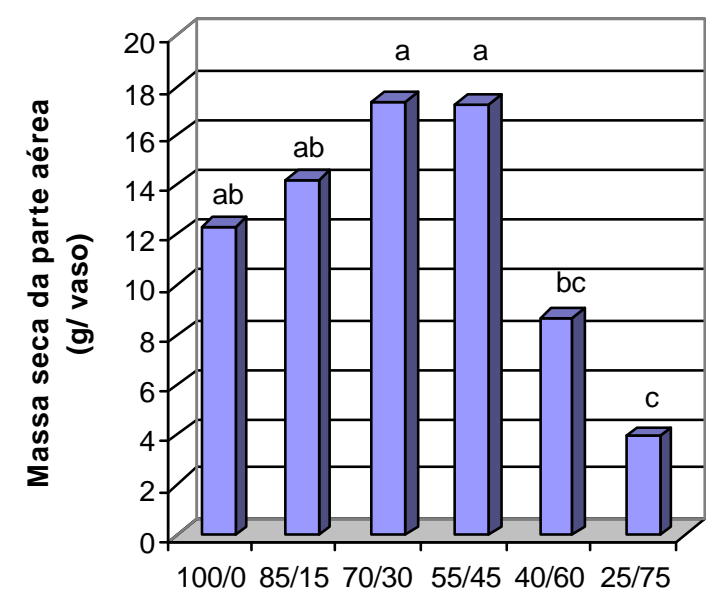

Proporções de nitrato/amônio

Figura 19 - Produção de massa seca da parte aérea do capim-Aruana, no segundo corte, em função das proporções de nitrato e amônio na solução nutritiva. Letras diferentes indicam diferença entre médias pelo teste de Tukey $(P<0,05)$

$\mathrm{Na}$ produção de massa seca da parte aérea do capim-Marandu ocorreu significância $(P<0,01)$ para as proporções de nitrato e amônio, tanto no primeiro como no segundo crescimento da planta. Pode-se observar (Figura 20) que o capimMarandu apresentou maiores respostas ao nitrogênio nas proporções de 85/15 e 70/30 de nitrato/amônio no primeiro crescimento. No segundo crescimento a maior produção da parte aérea desse capim foi verificada na proporção 70/30 (Figura 21). Abreu (1994) obteve maior produção de massa seca do capim-Marandu nas proporções de nitrato/amônio de 100/0 e 75/25 (sem cálcio).

De acordo com Santos (1997), a produção de massa seca da parte aérea da Brachiaria decumbens foi significativa $(P<0,01)$ para o nitrogênio na solução nutritiva. Verificou que as máximas produções de massa seca da parte aérea, no primeiro e segundo ciclo de crescimento da planta, foram obtidas com emprego de nitrogênio em doses mais elevadas (435 e $433 \mathrm{mg} \mathrm{L}^{-1}$ ) que a da solução nutritiva completa de Sarruge (1975). 
Ferragine (1998) observou significância $(P<0,01)$ para o nitrogênio na produção de massa seca do capim-braquiária, na ocasião do primeiro crescimento, mediante nitrogênio fornecido em solução nutritiva, com valores mais elevados que $210 \mathrm{mg} \mathrm{L}^{-1}$. Santos Junior (2001) também ressaltou que era necessário suprimento de nitrogênio em doses mais alta que $210 \mathrm{mg} \mathrm{L}^{-1}$ fornecido na proporção 70/30 de nitrato/amônio, para a obtenção da máxima produção de massa seca do capim-Marandu, relacionadas àdinâmica de crescimento das plantas.

Batista (2002) observou comportamento diferenciado entre o primeiro e o segundo crescimentos para a parte aérea do capim-Marandu. Mediante análise de superfície de resposta, no primeiro crescimento, a máxima produção de massa seca ocorreu na aplicação de nitrogênio de $510,8 \mathrm{mg} \mathrm{L}^{-1}$, enquanto que no segundo crescimento, este máximo ocorreu com nitrogênio de $369,8 \mathrm{mg} \mathrm{L}^{-1}$.

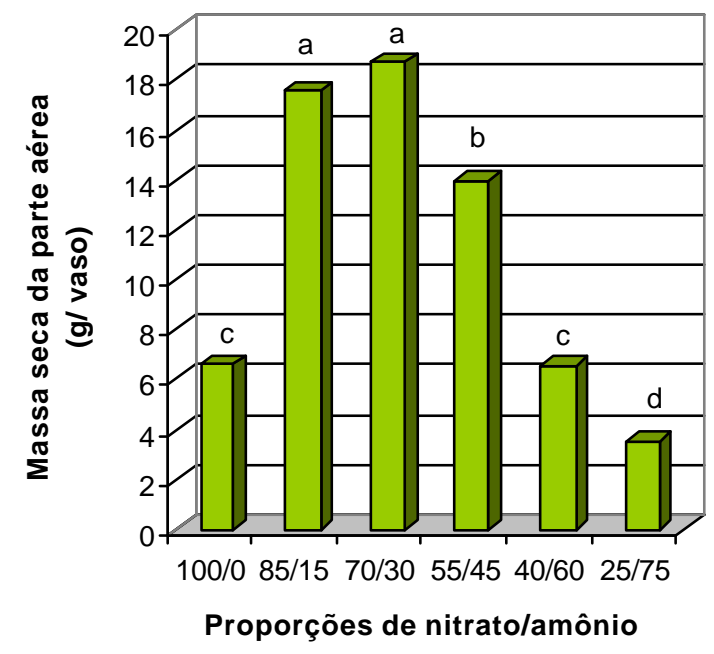

Figura 20 - Produção de massa seca da parte aérea do capim-Marandu, no primeiro corte, em função das propo rções de nitrato e amônio na solução nutritiva. Letras diferentes indicam diferença entre médias pelo teste de Tukey $(\mathrm{P}<0,05)$ 


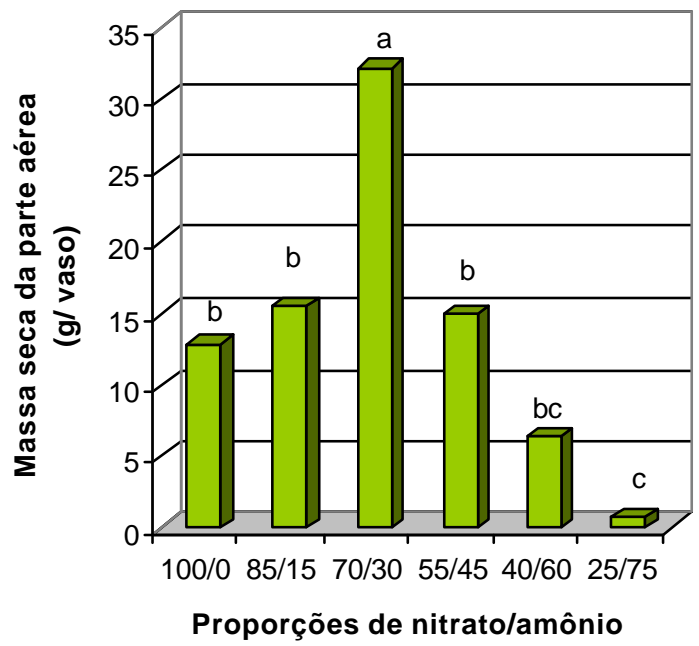

Figura 21 - Produção de massa seca da parte aérea do capim-Marandu, no segundo corte, em função das proporções de nitrato e amônio na solução nutritiva. Letras diferentes indicam diferença entre médias pelo teste de Tukey $(P<0,05)$

\subsubsection{Produção de massa seca de raízes}

A análise de variância dos resultados para a produção de massa seca de raízes do capim-Aruana revelou significância $(\mathrm{P}<0,01)$ para as proporções de nitrato/amônio. Constatou-se que a proporção de 55/45, que também foi semelhante à de 70/30 resultou em maior produção de massa seca de raízes nesse capim (Figura 22).

Estudo desenvolvido por Colozza (1998) com o capim-Aruana mostrou mais elevada produção de massa seca de raízes com emprego de nitrogênio de 262 $\mathrm{mg} \mathrm{kg}^{-1}$. Lavres Junior (2001) identificou que atingiria máxima produção de massa seca de raízes do capim-Mombaça, com o fornecimento de nitrogênio de $467 \mathrm{mg} \mathrm{L}^{-1}$.

Para o capim-Marandu, as proporções de nitrato/amônio foram significativas $(\mathrm{P}<0,01)$ na produção de massa seca de raízes, sendo a maior produção observada na proporção de 70/30, atingindo valores mais que duas vezes maiores æ̇̀ proporções que mais se aproximaram em produção de raízes (Figura 23). 
Os resultados observados neste experimento estão próximos daqueles de Abreu (1994), onde a proporção 75/25 de nitrato/amônio, na ausência de Ca, foi a que apresentou maior produção de massa seca do sistema radicular do capim-Marandu. Santos (1997) observou que as respostas ao nitrogênio para o capim-braquiária caracteriza que a concentração de nitrogênio de $210 \mathrm{mg} \mathrm{L}^{-1}$ de solução estabelecida no tratamento completo da solução de Sarruge (1975) não foi suficiente para atender as exigências para expressão do máximo potencial produtivo de raízes da braquiária.

Santos Junior (2001) observou que a máxima produção de massa seca de raízes do capim-Marandu, ocorreu com o fornecimento de nitrogênio em valores mais altos que $210 \mathrm{mg} \mathrm{L}^{-1}$ sendo eles 250; 270; 331; 355 e $243 \mathrm{mg} \mathrm{L}^{-1}$ compostos pela proporção 70/30 de nitrato/amônio, correspondente aos 28, 35, 42, 49 e 56 dias de crescimento, respectivamente.

Batista (2002) constatou que a produção de massa seca de raízes obteve o seu valor máximo quando utilizou nitrogênio em doses mais elevadas do que $210 \mathrm{mg} \mathrm{L}^{-1}$, respeitando a proporção de 70/30 de nitrato/amônio.

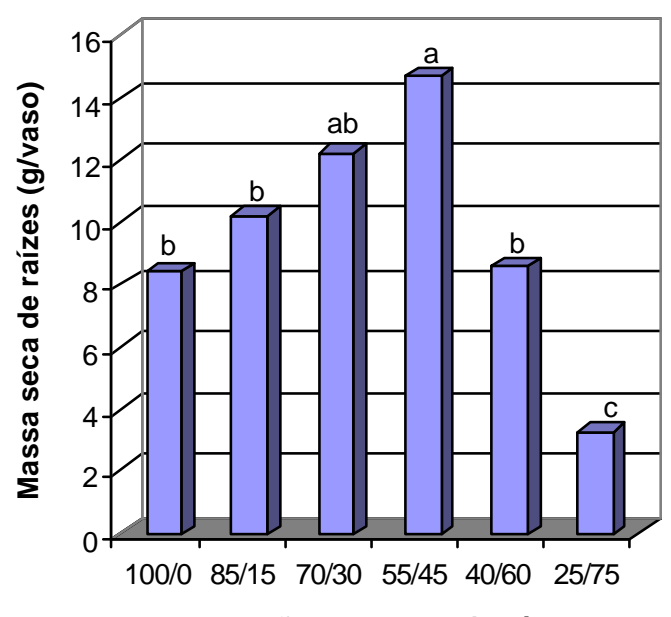

Proporções de nitrato/amônio

Figura 22 - Produção de massa seca de raízes do capim-Aruana, em função das proporções de nitrato e amônio na solução nutritiva. Letras diferentes indicam diferença entre médias pelo teste de Tukey $(P<0,05)$ 


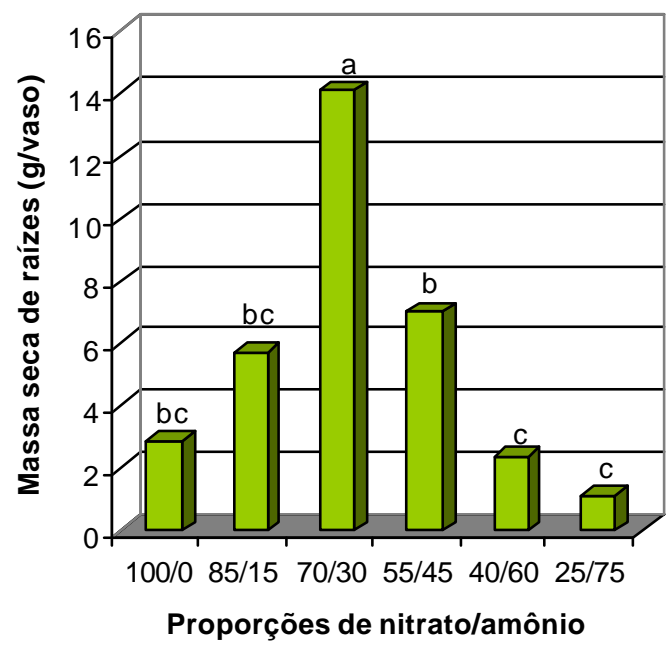

Figura 23 - Produção de massa seca de raízes do capim-Marandu, em função de proporções de nitrato e amônio na solução nutritiva. Letras diferentes indicam diferença entre médias pelo teste de Tukey $(P<0,05)$

\subsection{Concentração de nitrogênio total nas plantas}

\subsubsection{Folhas emergentes}

A análise de variância dos resultados do capim-Aruana, para o primeiro e segundo crescimentos, revelou que não houve significância $(P>0,05)$ na concentração de nitrogênio total nas folhas emergentes, para as proporções de nitrato/amônio. Para o capim-Marandu os resultados da concentração de nitrogênio nas folhas emergentes mostraram significância $(P<0,01)$ no primeiro e segundo crescimentos, em função das proporções de nitrato/amônio. No primeiro crescimento do capim-Marandu, a proporção de 100/0 foi a que apresentou valores mais elevados da concentração de nitrogênio nessa parte da planta (Figura 24). O mesmo resultado não foi verificado no segundo crescimento, observando-se que as proporções 70/30 e 25/75 apesar de apresentarem menor concentração de nitrogênio nessa parte da planta, diferiram estatisticamente das demais (Figura 25). 
Santos (1997) verificou que a aplicação de nitrogênio em doses mais altas que $210 \mathrm{mg} \mathrm{L}^{-1}$ a qual é composta com $100 \%$ de nitrato, proporcionou a máxima concentração de nitrogênio em folhas emergentes $\left(23,8 \mathrm{~g} \mathrm{~kg}^{-1}\right.$ de massa seca).

Manarin (2000) relatou ter havido respostas mais altas à medida que se aumentou as doses de nitrogênio na solução nutritiva, acima de $210 \mathrm{mg} \mathrm{L}^{-1}$ correspondendo a 100 \% de nitrato. Encontrou variação na concentração de nitrogênio de 11,4 a $24,5 \mathrm{~g} \mathrm{~kg}^{-1}$ de massa seca das folhas emergentes do capim-Mombaça, com o aumento das proporções de nitrato e amônio no segundo corte. Constatou que as folhas emergentes foram as que apresentaram maior concentração de nitrogênio no primeiro e segundo cortes, quando submetida a mais altas concentrações de nitrogênio na solução, justificando ser o resultado da translocação do nitrogênio para as partes mais novas da planta.

Lavres Junior (2001) ressaltou que houve incremento na concentração de nitrogênio nas folhas emergentes do capim-Mombaça, no primeiro corte, demonstrando que para a proporção 64,4/35,6 de nitrato/amônio que compõe a dose de $210 \mathrm{mg} \mathrm{L}^{-1}$, a concentração média foi $15,5 \%$ superior àconcentração obtida nas doses mais baixas de nitrogênio.

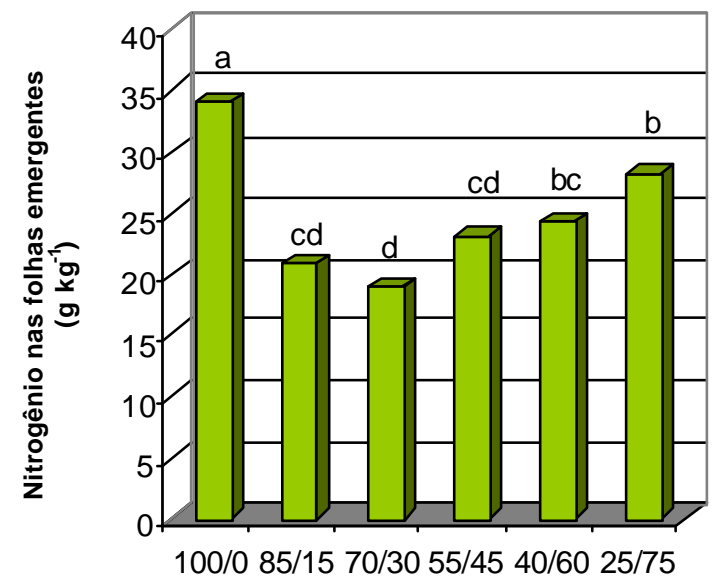

Proporções de nitrato/amônio

Figura 24 - Concentração de nitrogênio nas folhas emergentes do primeiro crescimento do capim-Marandu, em função das proporções de nitrato e amônio na solução nutritiva. Letras diferentes indicam diferença entre médias pelo teste de Tukey $(\mathrm{P}<0,05)$ 


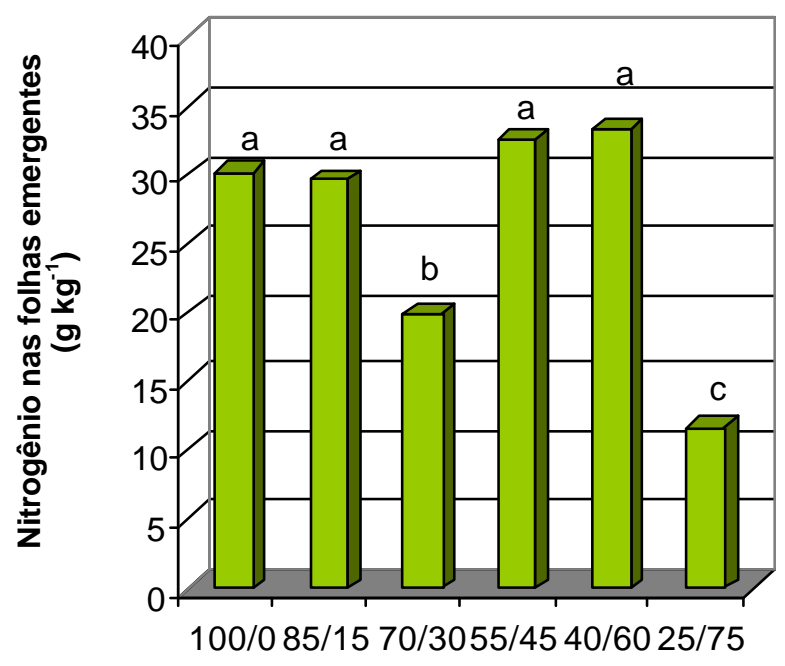

Proporções de nitrato/amônio

Figura 25 - Concentração de nitrogênio nas folhas emergentes do segundo crescimento do capim-Marandu, em função das proporções de nitrato e amônio na solução nutritiva. Letras diferentes indicam diferença entre médias pelo teste de Tukey $(P<0,05)$

\subsubsection{Lâminas de folhas recém-expandidas}

Avaliando a influência das proporções de nitrato/amônio na concentração de nitrogênio das lâminas de folhas recém-expandidas do capim-Aruana, verificou-se significância $(P<0,05)$ no primeiro crescimento, observando na figura 26 , que a proporção com mais alta concentração de amônio proporcionou mais elevada concentração de nitrogênio, supondo que 0 amônio tenha sido mais facilmente translocado para a formação dessa parte da planta. Para o segundo crescimento, a análise de variância dessa concentração de nitrogênio não mostrou significância $(P>0,05)$ para as proporções de nitrato/amônio.

As proporções de nitrato/amônio fizeram tariar significativamente $(P<0,01)$ e $(P<0,05)$ a concentração de nitrogênio nas lâminas de folhas recém-expandidas do capim-Marandu, no primeiro e segundo crescimentos, respectivamente. A mais elevada concentração de nitrogênio nessa parte da planta, no primeiro crescimento foi detectada na proporção de 100/0 com $34,13 \mathrm{~g} \mathrm{~kg}^{-1}$ de massa seca, que diferiu das 
mais baixas concentrações encontradas nas proporções de 85/15 e 70/30 com os valores de 19,06 e 18,56 $\mathrm{g} \mathrm{kg}^{-1}$ de massa seca, respectivamente (Figura 27). No segundo crescimento todas as proporções não diferenciaram-se estatisticamente (Figura 28).

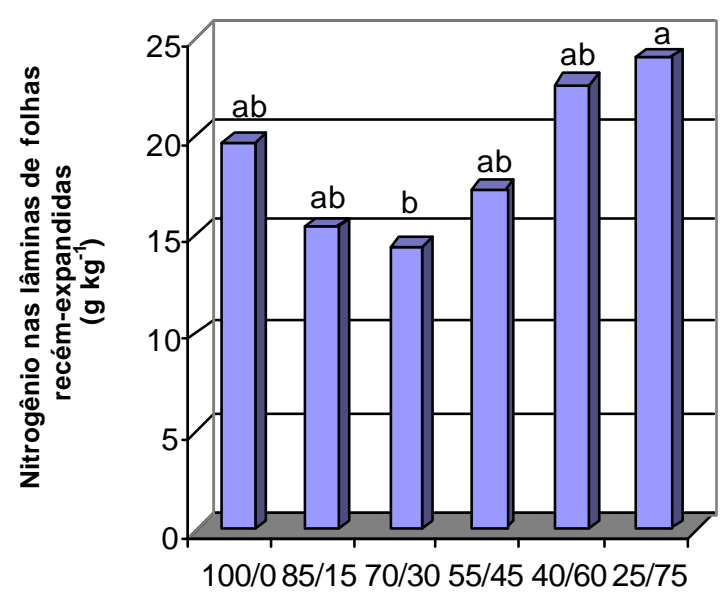

Proporções de nitrato/amônio

Figura 26 - Concentração de nitrogênio nas êminas de folhas recém-expandidas no primeiro crescimento do capim-Aruana, em função das proporções de nitrato e amônio na solução nutritiva. Letras diferentes indicam diferença entre médias pelo teste de Tukey $(P<0,05)$

A concentração de nitrogênio nas lâminas de folhas recém-expandidas, segundo Abreu (1994) apresentaram resultados significativos $(P<0,05)$ na proporção 75/25 (-Ca) de nitrato/amônio. Santos (1997) constatou que as respostas foram significativas $(P<0,01)$ para a concentração de nitrogênio nas lâminas de folhas recém expandidas, no primeiro crescimento do capim-Braquiária, apresentando variação de 12,6 a $27,5 \mathrm{~g} \mathrm{~kg}^{-1}$ de massa seca e ocorrendo nos limites das doses de nitrogênio utilizadas na solução nutritiva (0 e $462 \mathrm{mg} \mathrm{L}^{-1}$ ).

Manarim (2000), em estudo desenvolvido com o capim-Mombaça, verificou que os valores da concentração de nitrogênio nas lâminas de folhas recém-expandidas variaram de 8,8 a 18,5 e 10,2 a 19,2 $\mathrm{g} \mathrm{kg}^{-1}$ de massa seca, no primeiro e segundo crescimentos, respectivamente. Colozza et al. (2000) ressaltaram que a concentração de nitrogênio nas lâminas recém-expandidas do capim-Aruana variou de 12,8 a 43,5 
$\mathrm{g} \mathrm{kg}^{-1}$ na massa seca, em função da não-aplicação de nitrogênio até a aplicação de 300 $\mathrm{mg} \mathrm{kg}^{-1}$, respectivamente.

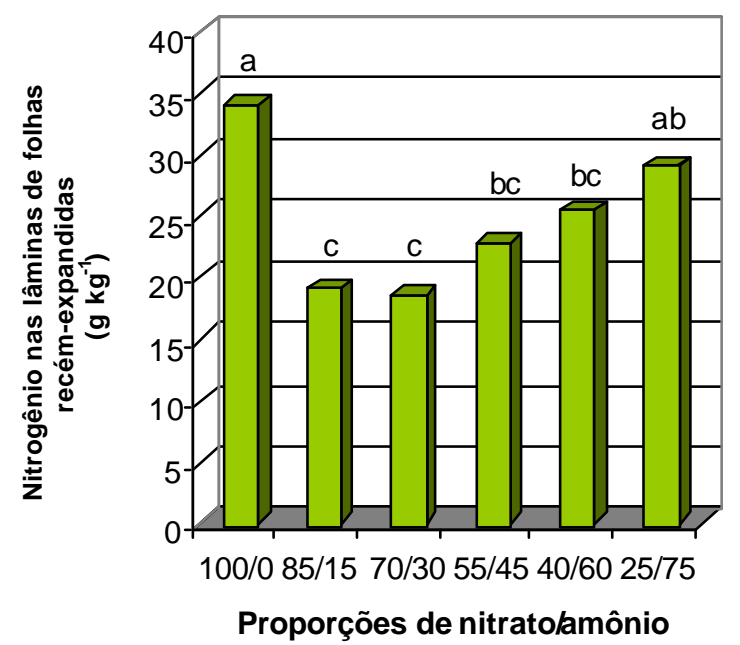

Figura 27 - Concentração de nitrogênio nas âminas de folhas recém-expandidas no primeiro crescimento do capim-Marandu, em função das proporções de nitrato e amônio na solução nutritiva. Letras diferentes indicam diferença entre médias pelo teste de Tukey $(P<0,05)$

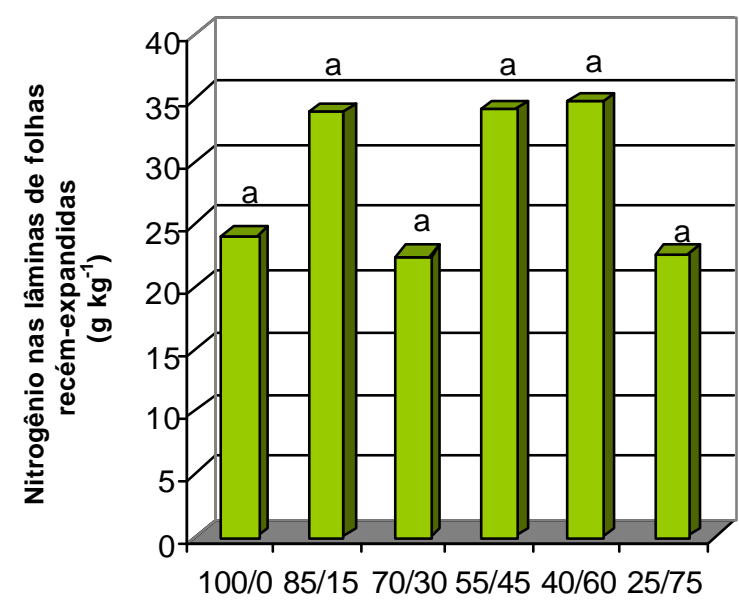

Proporções de nitrato/amônio

Figura 28 - Concentração de nitrogênio nas lâminas de folhas recém-expandidas no segundo crescimento do capim-Marandu, em função das proporções de nitrato e amônio na solução nutritiva. Letras diferentes indicam diferença entre médias pelo teste de Tukey $(P<0,05)$ 
Santos Junior (2001) observou que a concentração de nitrogênio nas lâminas de folhas recém-expandidas do capim-Marandu foi significativa $(P<0,01)$, para a proporção 70/30 de nitrato/amônio na dose de $210 \mathrm{mg} \mathrm{L}^{-1}$.

Batista (2002), em estudo com o capim-Marandu submetido a combinações de nitrogênio e enxofre, verificou resposta significativa $(P<0,01)$ nas lâminas de folhas recém-expandidas, para o nitrogênio fornecido na solução nutritiva, por ocasião do primeiro e segundo crescimentos. A mais alta concentração de nitrogênio nas lâminas de folhas recém-expandidas foi de $31 \mathrm{~g} \mathrm{~kg}^{-1}$ de massa seca e ocorreu na proporção de $70 / 30$ de nitrato/amônio com dose de nitrogênio mais elevada que $210 \mathrm{mg} \mathrm{L}^{-1}$. O intervalo entre a menor e maior concentração de nitrogênio nas folhas recémexpandidas, variou de 16 a $31 \mathrm{~g} \mathrm{~kg}^{-1}$.

\subsubsection{Lâminas de folhas maduras}

A análise de variância da concentração de nitrogênio nas lâminas de folhas maduras do capim-Aruana no primeiro crescimento não demonstrou alteração significativa $(P>0,05)$ com as proporções de nitrato/amônio. Entretanto, para o segundo crescimento do capim-Aruana ocorreu significância $(P<0,01)$ nessa variável. Os resultados das proporções de 100/0, 85/15, 40/60 e 25/75 de nitrato/amônio não diferiram estatísticamente entre si (Figura 29).

Para o capim-Marandu, em termos da concentração de nitrogênio nas folhas maduras a análise de variância revelou que não houve significância $(P>0,05)$ no primeiro crescimento, mas que ocorreu $(P<0,01)$ no segundo crescimento, para as proporções de nitrato/amônio (Figura 30).

Batista (2002) ressaltou que houve resposta significativa $(\mathrm{P}<0,05)$ para 0 nitrogênio fornecido na solução nutritiva, no primeiro crescimento do capim-Marandu. Verificou maiores concentrações de nitrogênio nessa parte da planta, quando o nitrogênio foi testado em doses maiores que $210 \mathrm{mg} \mathrm{L}^{-1}$ que corresponde a proporção 70/30 de nitrato/amônio. 


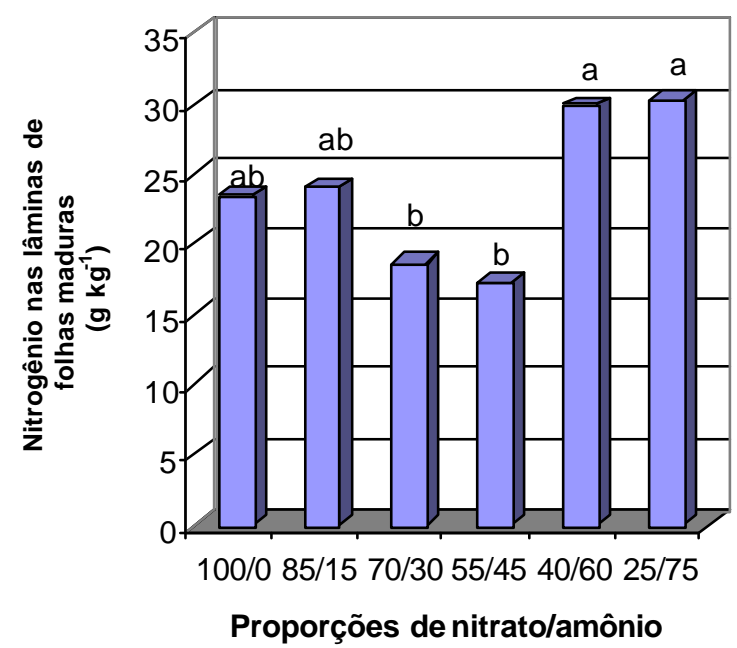

Figura 29 - Concentração de nitrogênio nas lâminas de folhas maduras no segundo crescimento do capim-Aruana, em função das proporções de nitrato e amônio na solução nutritiva. Letras diferentes indicam diferença entre médias pelo teste de Tukey $(\mathrm{P}<0,05)$

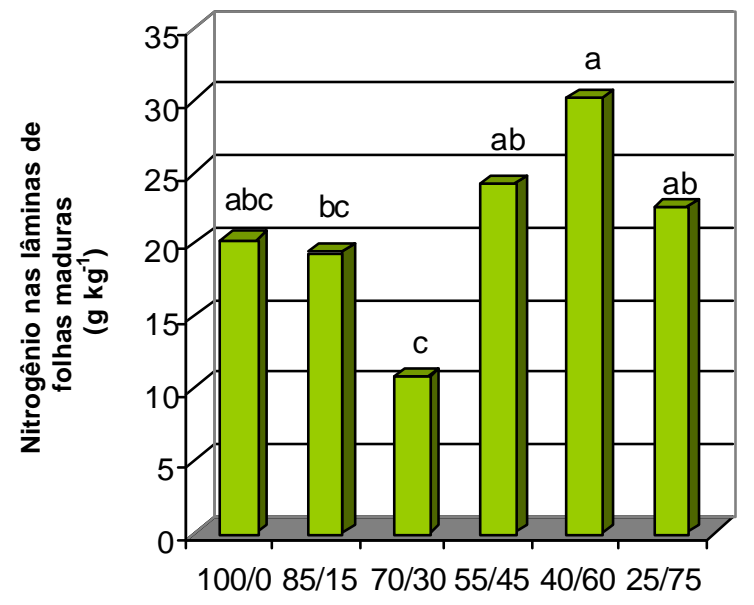

Proporções de nitrato/amônio

Figura 30 - Concentração de nitrogênio nas lâminas de folhas maduras no segundo crescimento do capim-Marandu, em função das proporções de nitrato e amônio na solução nutritiva. Letras diferentes indicam diferença entre médias pelo teste de Tukey $(P<0,05)$ 


\subsubsection{Colmos mais bainhas}

Os resultados da análise de variância para a concentração de nitrogênio mostraram variação significativa $(P<0,01)$ em função das proporções de nitrato/amônio no capim-Aruana, por ocasião do primeiro e segundo cortes. As proporções de 40/60 e 25/75 foram as que mostraram as mais elevadas concentrações de nitrogênio com 13,67 e 15,60 no primeiro crescimento e com 26,02 e $24,61 \mathrm{~g} \mathrm{~kg}^{-1}$ no segundo crescimento, respectivamente (Figuras 31 e 32 ).

Manarin (2000) apresentou resultados da concentração de nitrogênio nos colmos mais bainhas do capim-Mombaça no segundo crescimento, submetido ao nitrogênio na solução nutritiva, ressaltando que a concentração de nitrogênio neste capim variou de 6,35 a $15,9 \mathrm{~g} \mathrm{~kg}^{-1}$.

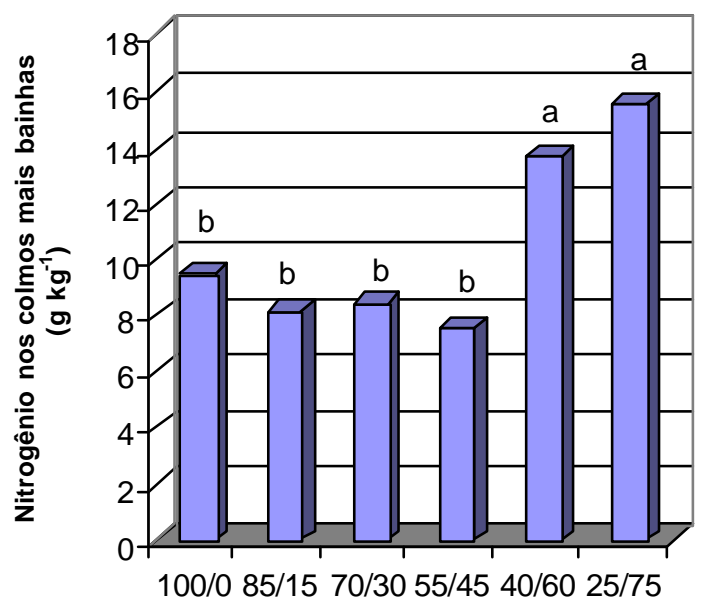

Proporções de nitrato/amônio

Figura 31 - Concentração de nitrogênio nos colmos mais bainhas no primeiro crescimento do capim-Aruana, em função das proporções de nitrato e amônio na solução nutritiva. Letras diferentes indicam diferença entre médias pelo teste de Tukey $(\mathrm{P}<0,05)$ 


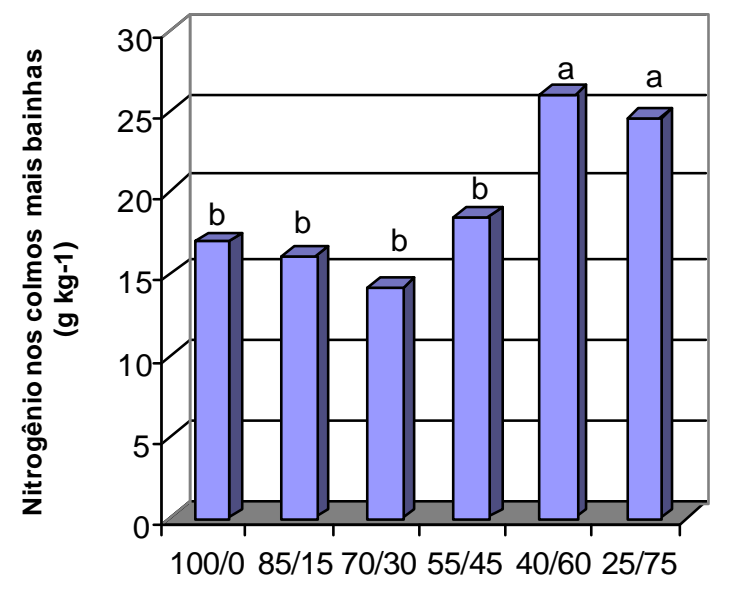

Proporções de nitrato/amônio

Figura 32 - Concentração de nitrogênio nos colmos mais bainhas no segundo crescimento do capim-Aruana, em função das proporções de nitrato e amônio na solução nutritiva. Letras diferentes indicam diferença entre médias pelo teste de Tukey $(\mathrm{P}<0,05)$

Lavres Junior (2001) constatou que a concentração de nitrogênio nos colmos mais bainhas do capim-Mombaça no primeiro corte variou entre 5,34 e 19,90 g kg-1 de massa seca com as doses mínima (28 $\left.\mathrm{mg} \mathrm{L}^{-1}\right)$ e máxima $\left(462 \mathrm{mg} \mathrm{L}^{-1}\right)$ de nitrogênio na solução nutritiva. Para o segundo corte verificou que a concentração de nitrogênio variou de 6,55 a 14,90 $\mathrm{g} \mathrm{kg}^{-1}$ de massa seca dos colmos mais bainhas. Na dose de 210 $\mathrm{mg} \mathrm{L}^{-1}$ a concentração de média foi cerca de $45 \%$ da concentração mais alta.

A concentração de nitrogênio nos colmos mais bainhas variou significativamente $(P<0,01)$ com as proporções de nitrato/amônio no primeiro e segundo crescimentos do capim-Marandu. As proporções de 100/0, 40/60 e 25/75 não diferiram entre si (Figura 33), enquanto que no segundo crescimento as proporções 55/45, 40/60 e 25/75 diferem de 70/30 (Figura 34). A maior concentração de nitrogênio no tecido dos colmos mais bainhas foi de 23,13 e $23,21 \mathrm{~g} \mathrm{~kg}^{-1}$ de massa seca, respectivamente para o primeiro e segundo crescimentos. 


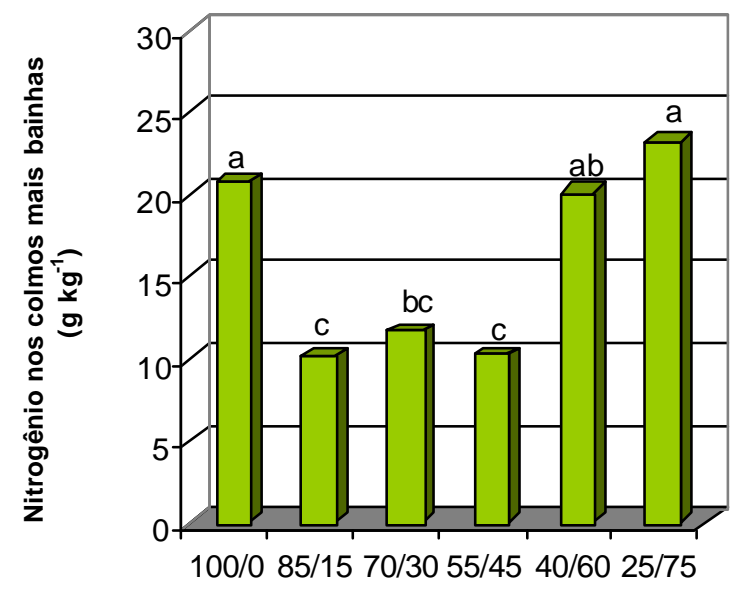

Proporções de nitrato/amônio

Figura 33 - Concentração de nitrogênio nos colmos mais bainhas no primeiro crescimento do capim-Marandu, em função das proporções de nitrato e amônio na solução nutritiva. Letras diferentes indicam diferença entre médias pelo teste de Tukey $(P<0,05)$

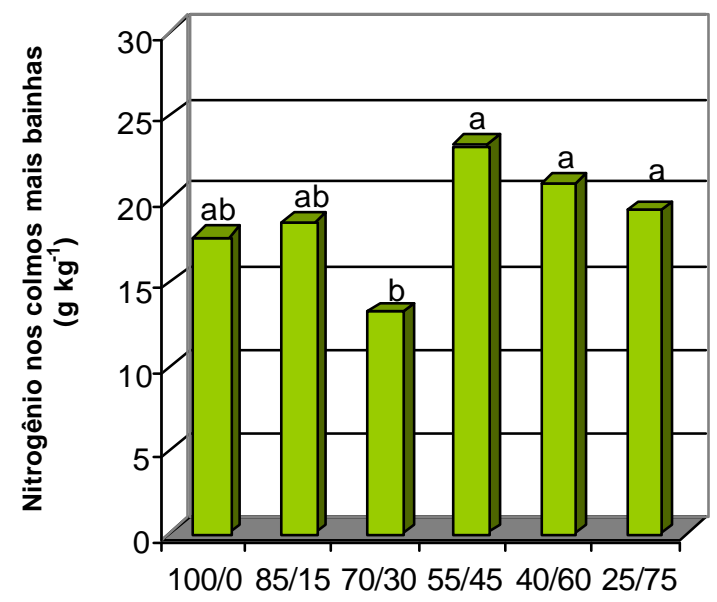

Proporções de nitrato/amônio

Figura 34 - Concentração de nitrogênio nos colmos mais bainhas no segundo crescimento do capim-Marandu, em função das proporções de nitrato e amônio na solução nutritiva. Letras diferentes indicam diferença entre médias pelo teste de Tukey $(P<0,05)$ 
Abreu (1994) constatou, no capim-Marandu, que a proporção de nitrato/amônio de 75/25 em ausência de cálcio foi a que resultou em mais alta concentração de nitrogênio total nos colmos mais bainhas, realizando o corte aos 71 dias de crescimento. Santos (1997) observou que a concentração de nitrogênio nos colmos mais bainhas do capim-Braquiária, no primeiro crescimento, apresentou respostas mais elevadas para o nitrogênio empregado na solução nutritiva, ressaltando que foi o componente da parte aérea com mais baixa concentração de nitrogênio.

Batista (2002) relatou que a concentração de nitrogênio nos colmos mais bainhas do capim-Marandu foi significativamente $(P<0,01)$ influenciada pelo nitrogênio fornecido na solução nutritiva, por ocasião do primeiro crescimento, enquanto que para o segundo crescimento não foi verificada tal significância $(P>0,05)$. De acordo com 0 ajuste da equação de segundo grau a concentração de nitrogênio variou de 13,9 a 31,4 $\mathrm{g} \mathrm{kg}^{-1}$ da mais baixa até a mais elevada dose de nitrogênio, composta pela proporção 70/30 de nitrato/amônio na solução nutritiva.

\subsubsection{Raízes}

$\mathrm{Na}$ análise de variância da concentração de nitrogênio nas raízes do capimAruana verificou-se variação significativa $(P<0,01)$ para as proporções de nitrato e amônio. As mais elevadas concentrações foram observadas nas proporções de 100/0 e 85/15 de nitrato/amônio, com os valores 19,90 e $20,75 \mathrm{~g} \mathrm{~kg}^{-1}$, respectivamente na massa seca de raízes (Figura 35).

Abreu (1994), ao realizar experimento com os capins Gordura, Marandu e Tanzânia, relatou que não foi significativa $(P>0,05)$ a variação na concentração de nitrogênio nas raízes, para as proporções de nitrato/amônio nos três capins estudados. Para o capim-Tanzânia a mais alta concentração de nitrogênio encontrada na massa seca das raízes (12,0 $\mathrm{g} \mathrm{kg}^{-1}$ ) ocorreu na proporção de 75/25 (sem cálcio). Manarin (2000), em estudo com nitrogênio no capim-Mombaça, encontrou efeitos significativos $(\mathrm{P}<0,01)$ para a concentração de nitrogênio nas raízes, cujos valores encontrados variaram de 8,2 a $18,6 \mathrm{~g} \mathrm{~kg}^{-1}$.

Lavres Junior (2001) constatou que a mais elevada concentração de nitrogênio na massa seca das raízes do capim-Mombaça foi de $24,53 \mathrm{~g} \mathrm{~kg}^{-1}$ e ocorreu com a utilização de nitrogênio de $462 \mathrm{mg} \mathrm{L}^{-1}$. Também verificou que a mais elevada 
concentração desse nutriente nas raízes ocorreria com o emprego de nitrogênio de 617 $\mathrm{mg} \mathrm{L}^{-1}$ na solução.

Os resultados da concentração de nitrogênio na massa seca de raízes do capim-Marandu sofreram alteração significativa $(P<0,01)$ com as proporções de nitrato/amônio, entretanto as proporções de 100/0, 85/15, 40/60 e 25/75 não apresentaram diferenças estatística entre si, mas foram as que proporcionaram os mais altos valores absolutos na concentração de nitrogênio na massa seca das raízes desse capim (Figura 36).

Para o capim-Marandu, Abreu (1994) constatou que a mais elevada concentração de nitrogênio na massa seca de raízes foi encontrada na proporção de $50 / 50$ de nitrato/amônio, com o valor de $13,0 \mathrm{~g} \mathrm{~kg}^{-1}$. No presente trabalho a concentração de nitrogênio nesta parte da planta variou de 8,1 a $13,0 \mathrm{~g} \mathrm{~kg}^{-1}$. Santos (1997) demonstrou que houve efeito significativo $(P<0,01)$ da utilização de nitrogênio na solução nutritiva para a concentração desse nutriente nas raízes do capimBraquiária e verificou a mais alta concentração de nitrogênio foi de $10,9 \mathrm{~g} \mathrm{~kg}^{-1}$ de massa seca, obtida com nitrogênio de $452 \mathrm{mg} \mathrm{L}^{-1}$ na solução nutritiva.

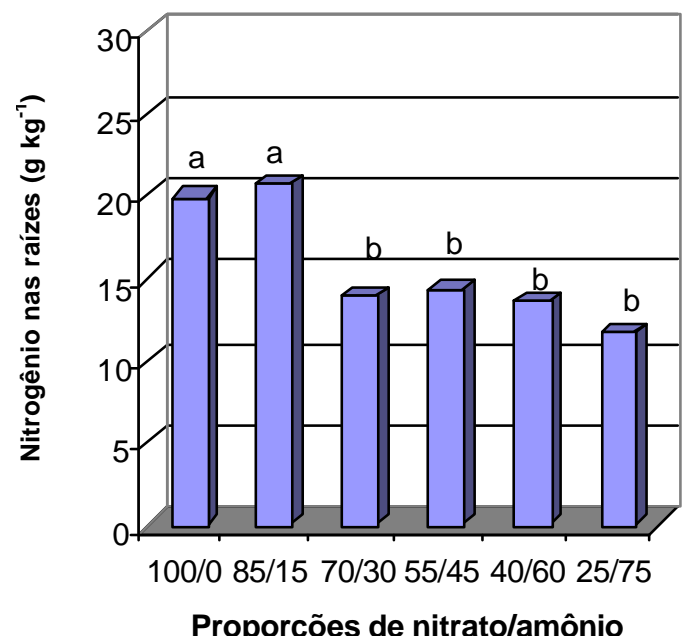

Figura 35 - Concentração de nitrogênio nas raízes do capim-Aruana, em função das proporções de nitrato e amônio na solução nutritiva. Letras diferentes indicam diferença entre médias pelo teste de Tukey $(P<0,05)$ 


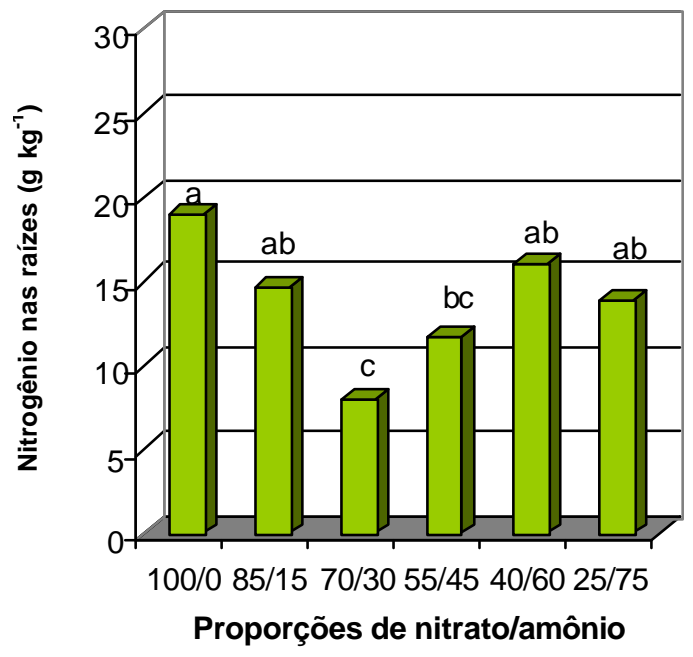

Figura 36 - Concentração de nitrogênio nas raízes do capim-Marandu, em função das proporções de nitrato e amônio na solução nutritiva. Letras diferentes indicam diferença entre médias pelo teste de Tukey $(P<0,05)$

\subsection{Concentração de nitrato na planta}

\subsubsection{Folhas emergentes, lâminas de folhas recém-expandidas, lâminas de folhas maduras e colmos mais bainhas}

A análise de variância não mostrou variação significativa $(P>0,05)$ na concentração de nitrato nas folhas emergentes, nas lâminas de folhas recémexpandidas, lâminas de folhas maduras e colmos mais bainhas do capim-Aruana para as proporções de nitrato e amônio na solução nutritiva, no material colhido no primeiro e segundo cortes das plantas.

Abreu (1994) observou que a mais elevada concentração de nitrato nas lâminas de folhas recém-expandidas do capim-Tanzânia ocorreu na proporção de 75/25 (sem cálcio), para as lâminas de folhas maduras foi obtida na proporção de 100/0 e nos colmos mais bainhas foi constatada na proporção de 75/25 de nitrato/amônio na solução nutritiva. 
No capim-Marandu, a análise de variância dos resultados da concentração de nitrato nas folhas emergentes, nas lâminas de folhas recém-expandidas e nas lâminas de folhas maduras também não revelou significância $(P>0,05)$ para as proporções de nitrato e amônio, tanto no material coletado no primeiro quanto no segundo corte das plantas.

Abreu (1994) ressaltou que a proporção de 75/25 de nitrato/amônio foi a que mostrou mais alta concentração de nitrato nas lâminas de folhas recém-expandidas do capim-Marandu e que nas lâminas de folhas maduras as proporções de 75/25 (sem cálcio) e de 100/0 (nitrato/amônio) foram as que apresentaram mais elevada concentração de nitrato.

A análise de variância da concentração de nitrato nos colmos mais bainhas do capim-Marandu, correspondente ao primeiro e segundo cortes, demonstrou significância $(P<0,01)$ para as proporções de nitrato/amônio, obtendo-se mais alta concentração de nitrato na proporção de 100/0 (Figuras 37) e nas proporções 100/0 e 85/15 (Figura 38). Este resultado é similar ao encontrado por Abreu (1994) referindo-se à concentração de nitrato nos colmos mais bainhas do capim-Marandu, no qual realizou um corte da planta aos 71 dias após o transplante.

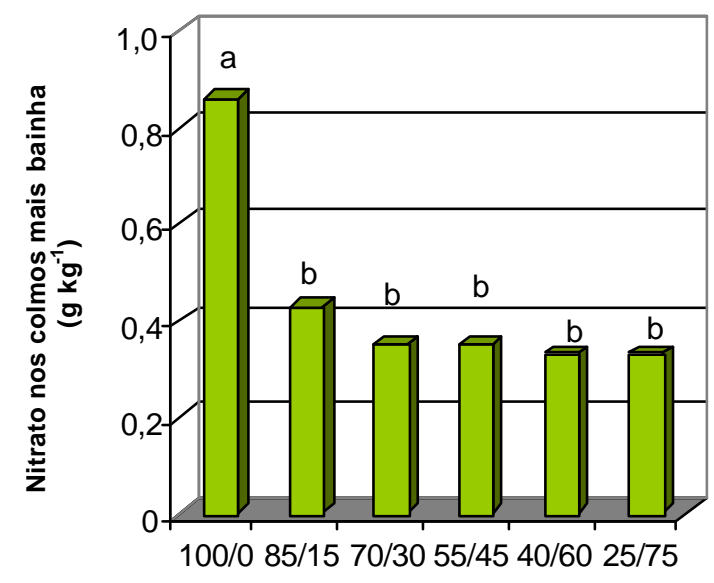

Proporções de nitrato/amônio

Figura 37 - Concentração de nitrato nos colmos mais bainhas no primeiro crescimento do capim-Marandu, em função das proporções de nitrato e amônio na solução nutritiva. Letras diferentes indicam diferença entre médias pelo teste de Tukey $(P<0,05)$ 


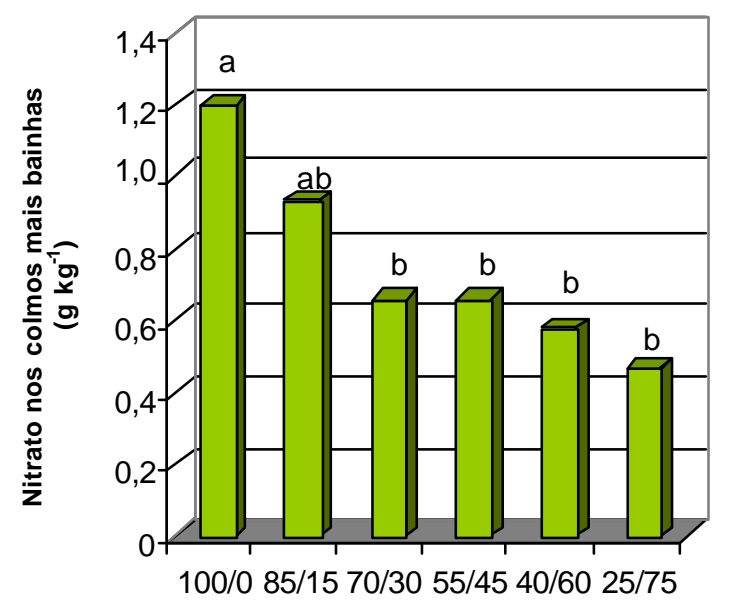

Proporções de nitrato/amônio

Figura 38 - Concentração de nitrato nos colmos mais bainhas no segundo crescimento do capim-Marandu, em função das proporções de nitrato e amônio na solução nutritiva. Letras diferentes indicam diferença entre médias pelo teste de Tukey $(\mathrm{P}<0,05)$

É importante ressaltar que ocorreu uma mais elevada concentração de nitrato nos colmos mais bainhas das plantas quando se forneceu $100 \%$ de nitrato nos $210 \mathrm{mg} \mathrm{L}^{-1}$ de nitrogênio. Hageman et al. (1979) relataram que este fato pode ocorrer devido ao nitrato acumular-se num "pool" inativo com permanência pequena no citoplasma ("pool" ativo), verificando que quando há necessidade o nutriente armazenado pode ser distribuído pela parte aérea da planta. Marschner (1995) relatou que o nitrato pode acumular-se nos vacúolos da planta quando ocorre mais elevado fornecimento dessa forma de nitrogênio.

\subsubsection{Raízes}

A concentração de nitrato nas raízes teve variação significativa $(P<0,05)$ no capim-Aruana para as proporções de nitrato/amônio na solução. Observou-se que as proporções de 100/0, 85/15 e 55/45 não diferiram estatisticamente entre si (Figuras 39) e no capim-Marandu, as proporções 100/0, 85/15 e 25/75 não diferem entre si (Figuras 40) 


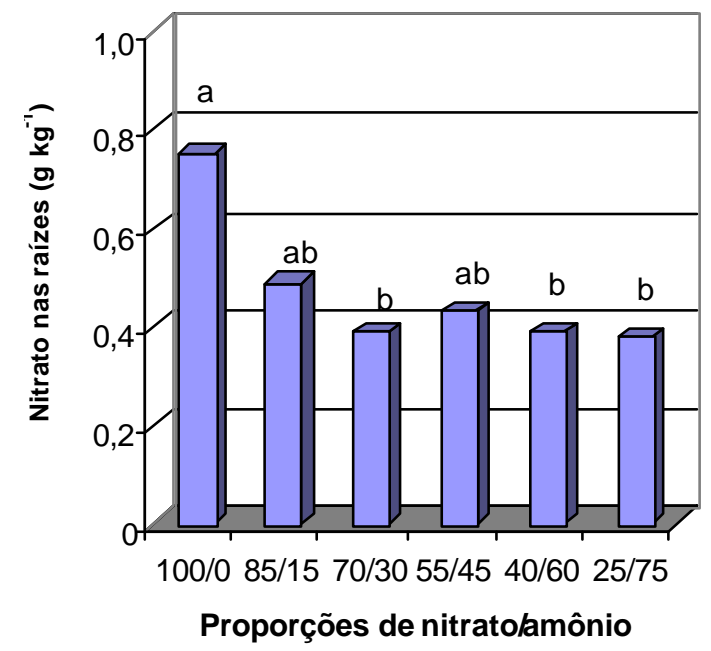

Figura 39 - Concentração de nitrato nas raízes do capim-Aruana, em função das proporções de nitrato e amônio na solução nutritiva. Letras diferentes indicam diferença entre médias pelo teste de Tukey $(P<0,05)$

Silveira (1981) verificou diminuição na concentração de nitrato translocado das raízes para a parte aérea à medida em que houve fornecimento de mais amônio na solução nutritiva, observando também mais alta concentração de nitrato no sistema radicular até a proporção de 25/75 de nitrato/amônio.

Abreu (1994) constatou que a concentração de nitrato no sistema radicular do capim-Tanzânia e do capim-Marandu variou significativamente $(P<0,05)$ com as proporções de nitrato/amônio, ressaltando que a proporção de 100/0 foi a que apresentou mais elevada concentração de nitrato nas raízes.

Andrade (1994) ressaltou que à medida em que se aumentava a participação do amônio na solução nutritiva, ocorria uma diminuição da concentração de nitrato nas raízes do capim-Colonião. Blacquiere et al. (1988) relataram que este fato pode ser um indicativo de que, na presença de amônio, o nitrato absorvido é translocado para a parte aérea da planta, onde é preferencialmente reduzido, enquanto a assimilação de amônio é mantida nas raízes. 


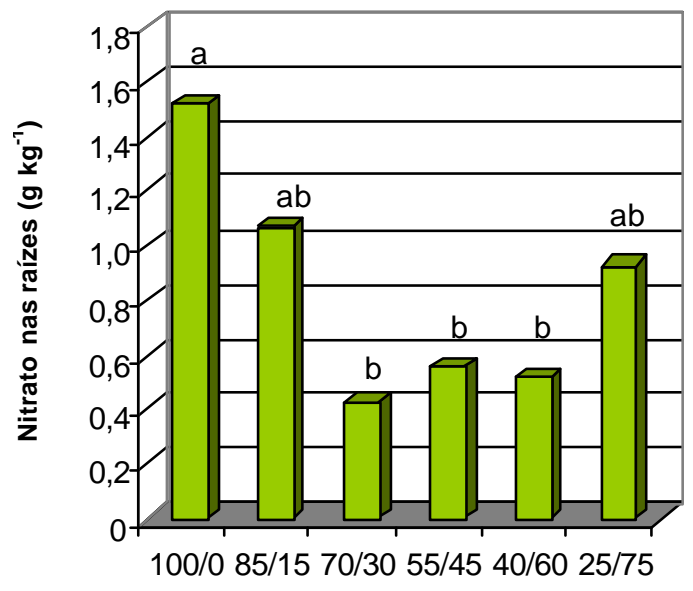

Proporções de nitrato/amônio

Figura 40 - Concentração de nitrato nas raízes do capim-Marandu, em função das proporções de nitrato e amônio na solução nutritiva. Letras diferentes indicam diferença entre médias pelo teste de Tukey $(P<0,05)$

\subsection{Concentração de amônio nas plantas}

\subsubsection{Folhas emergentes, lâminas de folhas recém-expandidas, lâminas de folhas maduras e colmos mais bainhas}

A concentração de amônio nas folhas emergentes, nas lâminas de folhas recém-expandidas e nos colmos mais bainhas do capim-Aruana não apresentou variação significativa $(P>0,05)$ com as proporções de nitrato e amônio, no material do primeiro e segundo cortes das plantas. Entretanto, para as lâminas de folhas maduras foi constatada significância $(\mathrm{P}<0,01)$ para as proporções de nitrato/amônio, tanto no primeiro como no segundo corte do capim-Aruana. Foi observado que as concentrações de amônio no primeiro corte diferiram nas proporções de 100/0, 70/30, 55/45, 40/60 e 25/75 de nitrato/amônio, respectivamente, porém não diferiram entre si (Figuras 41) e para o segundo corte foi verificado mais elevada concentração de amônio nas folhas maduras nas proporções 40/60 e 25/75 de nitrato/amônio (Figura 42). 


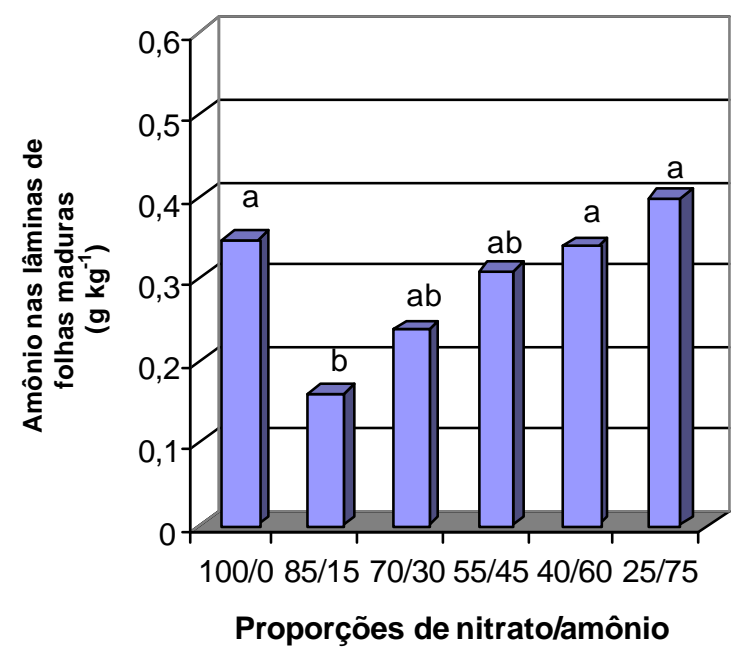

Figura 41 - Concentração de amônio nas lâminas de folhas maduras no primeiro crescimento do capim-Aruana, em função das proporções de nitrato e amônio na solução nutritiva. Letras diferentes indicam diferença entre médias pelo teste de Tukey $(\mathrm{P}<0,05)$

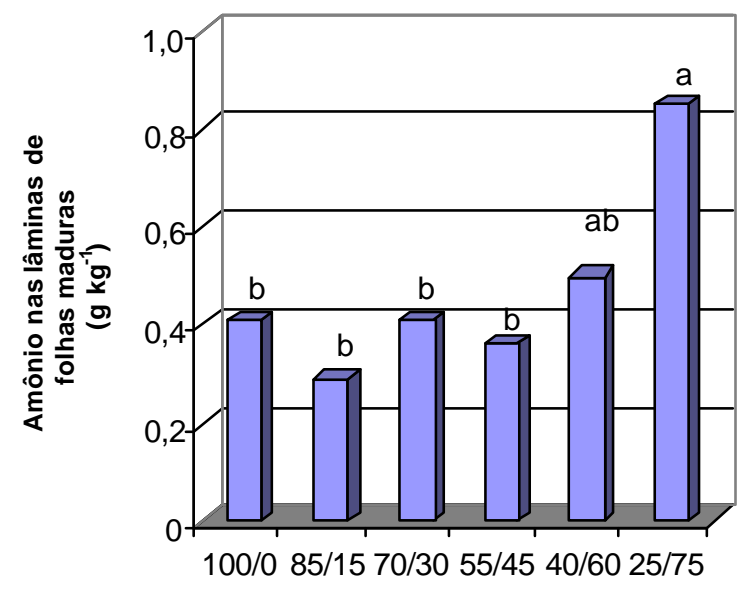

Proporções de nitrato/amônio

Figura 42 - Concentração de amônio nas lâminas de folhas maduras no segundo crescimento do capim-Aruana, em função das proporções de nitrato e amônio na solução nutritiva. Letras diferentes indicam diferença entre médias pelo teste de Tukey $(\mathrm{P}<0,05)$ 
Abreu (1994) ressaltou que a concentração de amônio nas lâminas de folhas recém-expandidas do capim-Tanzânia não apresentou significância $(P>0,05)$ para as proporções de nitrato/amônio. Também relatou que a mais alta concentração de amônio nessa parte da planta ocorreu na proporção de 50/50. Para a concentração de amônio nas lâminas de folhas maduras do capim-Tanzânia obteve significância $(\mathrm{P}<0,05)$ para as proporções de nitrato/amônio, enquanto para os colmos mais bainhas não ocorreu variação significativa $(P>0,05)$ e a mais alta concentração de amônio nas lâminas de folhas maduras do capim-Marandu ocorreu na proporção 100/0 de nitrato e amônio.

A análise de variância da concentração de amônio nas folhas emergentes e nas lâminas de folhas recém-expandidas do capim-Marandu mostrou que não houve significância $(P>0,05)$, tanto no primeiro como no segundo corte da gramínea. Para as lâminas de folhas maduras os resultados demonstraram significância $(P<0,01)$ æ̀s proporções de nitrato e amônio, no primeiro e segundo cortes. Obteve-se a mais alta concentração de amônio nas proporções de 25/75 e 40/60 para o primeiro e segundo cortes, respectivamente (Figuras 43 e 44).

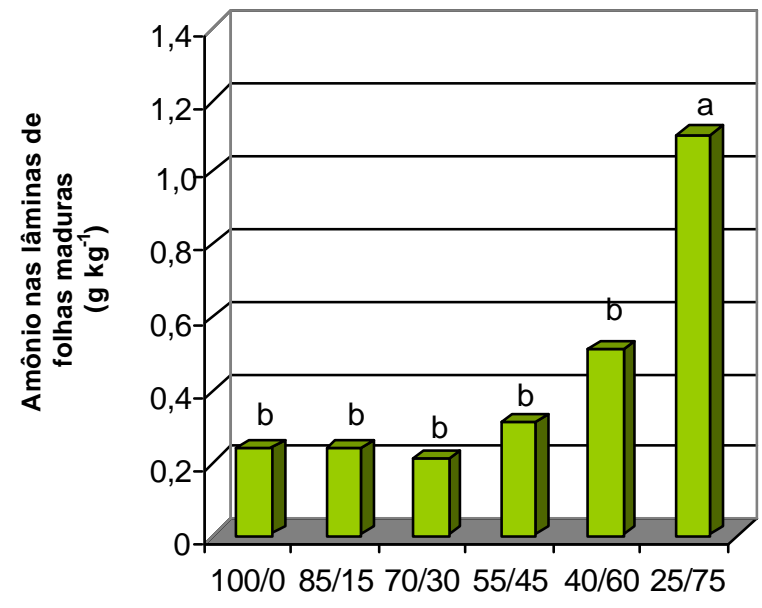

Proporções de nitrato/amônio

Figura 43 - Concentração de amônio nas lâminas de folhas maduras no primeiro crescimento do capim-Marandu, em função das proporções de nitrato e amônio na solução nutritiva. Letras diferentes indicam diferença entre médias pelo teste de Tukey $(\mathrm{P}<0,05)$ 
De acordo com Abreu (1994) a concentração de amônio nas lâminas de folhas recém-expandidas do capim-Marandu não foi significativamente $(P>0,05)$ alterada pelas proporções de nitrato/amônio. Entretanto, as lâminas de folhas maduras apresentaram variação significativa $(P<0,01)$ com as proporções de nitrato/amônio na solução nutritiva, obtendo o valor mais elevado de amônio na proporção de 25/75.

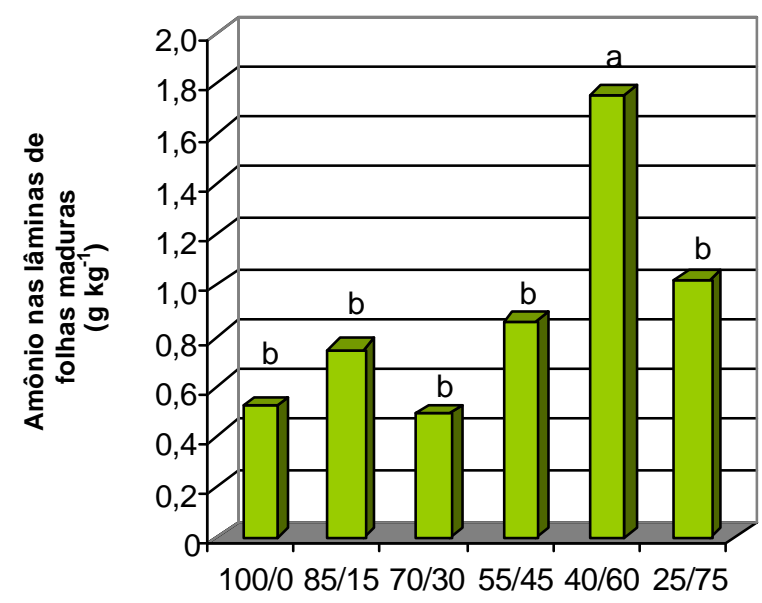

Proporções de nitrato/amônio

Figura 44 - Concentração de amônio nas lâminas de folhas maduras no segundo crescimento do capim-Marandu, em função das proporções de nitrato e amônio na solução nutritiva. Letras diferentes indicam diferença entre médias pelo teste de Tukey $(\mathrm{P}<0,05)$

A análise de variância dos resultados da concentração de amônio nos colmos mais bainhas do capim-Marandu mostrou significância $(P<0,01)$ para as proporções de nitrato e amônio. No primeiro corte a concentração de amônio não diferiu entre as proporções de 40/60 e 25/75 (Figura 45) e no segundo corte a mais alta concentração de amônio ocorreu na proporção de $25 / 75$, que teve resultado $71 \%$ maior que o da proporção 40/60 de nitrato/amônio (Figura 46). No segundo crescimento do capimMarandu o amônio acumulou-se nos vacúolos dos colmos mais bainhas. 


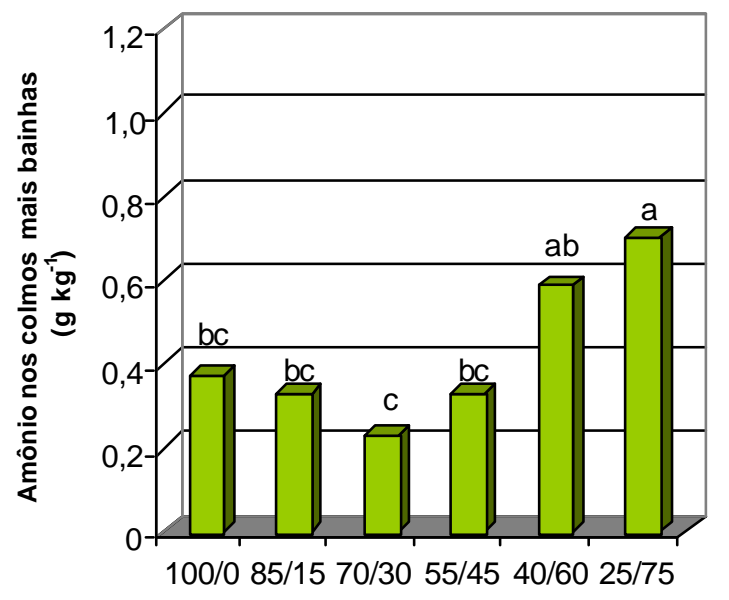

Proporções denitrato/amônio

Figura 45 - Concentração de amônio nos colmos mais bainhas no primeiro crescimento do capim-Marandu, em função das proporções de nitrato e amônio na solução nutritiva. Letras diferentes indicam diferença entre médias pelo teste de Tukey $(P<0,05)$

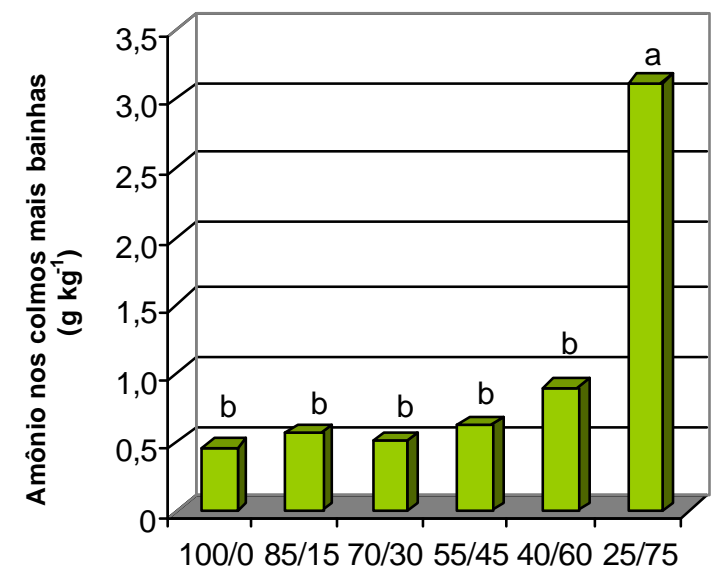

Proporções de nitrato/amônio

Figura 46 - Concentração de amônio nos colmos mais bainhas no segundo crescimento do capim-Marandu, em função das proporções de nitrato e amônio na solução nutritiva. Letras diferentes indicam diferença entre médias pelo teste de Tukey $(P<0,05)$ 
Na proporção de 25/75 que apresenta mais alta concentração de amônio nas lâminas de folhas maduras verificou-se menor produção de massa seca da parte aérea total, o que pode ser visto como uma possível toxicidade por amônia, que foi aumentada pela concentração de amônia livre na solução. Isto pode ser uma indicação que os capins Aruana e Marandu possuem baixa capacidade de utilizar apenas o amônio como forma de nitrogênio.

Abreu (1994) verificou que não ocorreu variação signifcativa $(P>0,05)$ para as proporções de nitrato e amônio na solução nutritiva, em termos da concentração de amônio nos colmos mais bainhas. Para essa parte da planta observou que as mais elevadas concentrações de amônio foram encontradas nas proporções de 100/0, 75/25 (sem cálcio) e 50/50 de nitrato/amônio.

\subsubsection{Raízes}

A concentração de amônio nas raízes do capim-Aruana não variou significativamente $(P>0,05)$ com as proporções de nitrato e amônio na solução nutritiva. Porém, no capim-Marandu foi constatada significância $(P<0,01)$ para as proporções de nitrato e amônio em relação à concentração de amônio das raízes, verificando que não houve diferença significativa entre as proporções 55/45, 40/60 e 25/75 (Figura 47).

Andrade (1994) em estudo com o capim-Colonião, relatou aumento na concentração de amônio nas raízes a partir do momento em que se incrementava a proporção de amônio na solução nutritiva.

Abreu (1994) observou alteração significativa $(P<0,01)$ na concentração de amônio nas raízes do capim-Marandu, em função das proporções de nitrato e amônio, tendo encontrado os mais altos valores de concentração de amônio nas proporção de 100/0 e 75/25. Ressaltou que houve queda nos valores da concentração de amônio nas raízes àmedida em que aumentou a participação do amônio na solução nutritiva e concluiu que nas raízes foram obtidas as mais baixas concentrações de amônio, em comparação com as outras partes da planta. 


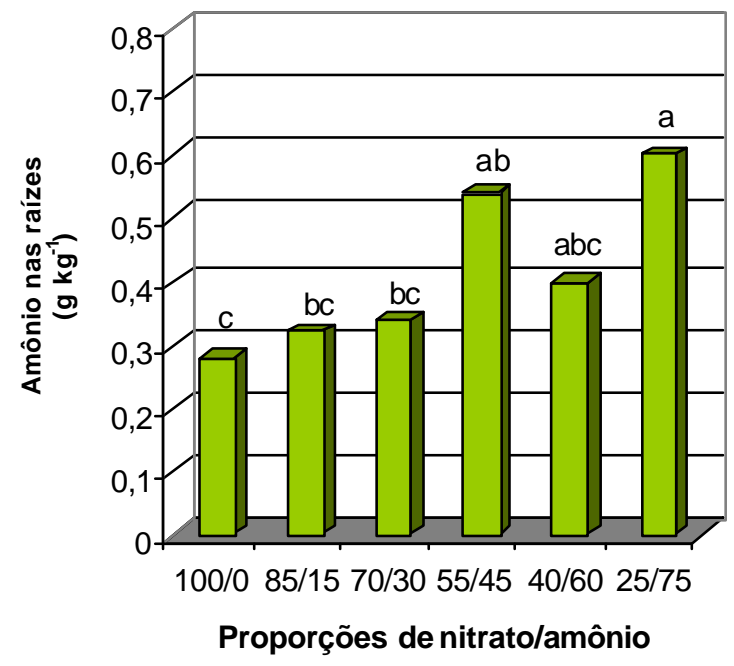

Figura 47 - Concentração de amônio nas raízes do capim-Marandu, em função das proporções de nitrato e amônio na solução nutritiva. Letras diferentes indicam diferença entre médias pelo teste de Tukey $(P<0,05)$

\subsection{Relação nitrato/amônio nas plantas}

\subsubsection{Relação nitrato/amônio nas folhas emergentes, lâminas de folhas recém- expandidas e colmos mais bainhas}

A análise de variância para a relação nitrato/amônio nas folhas emergentes, nas lâminas de folhas recém -expandidas e nos colmos mais bainhas no primeiro e segundo cortes do capim-Aruana não revelou significância $(P>0,05)$ para as proporções de nitrato/amônio na solução nutritiva.

Nas lâminas de folhas maduras do capim-Aruana, verificou-se significância $(\mathrm{P}<0,01)$ para a relação nitrato/amônio, em função das proporções de nitrato e amônio na solução nutritiva. No primeiro crescimento, a relação nitrato/amônio foi semelhante nas proporções de 85/15, 70/30, 40/60 e 25/75 de nitrato e amônio (Figura 48). Entretanto, por ocasião do segundo corte, a relação nitrato/amônio nas lâminas de folhas maduras não sofreu alteração significativa $(P>0,05)$ com as proporções de nitrato e amônio. 
No capim-Marandu, a análise de variância para a relação nitrato/amônio nas folhas emergentes e nas lâminas de folhas maduras, em ambos os cortes da forrageira e no segundo corte para as lâminas de folhas recém-expandidas também não apresentou variação significativa $(P>0,05)$ para as proporções de nitrato e amônio na solução. Porém, no primeiro corte das plantas, nas lâminas de folhas recémexpandidas houve significância $(P<0,05)$ na relação nitrato/amônio em função das proporções desses dois íons na solução nutritiva, verificando-se que a relação não foi estatisticamente diferente, nas proporções de 100/0, 85/15, 70/30, 55/45 e 40/60 (Figura 49).

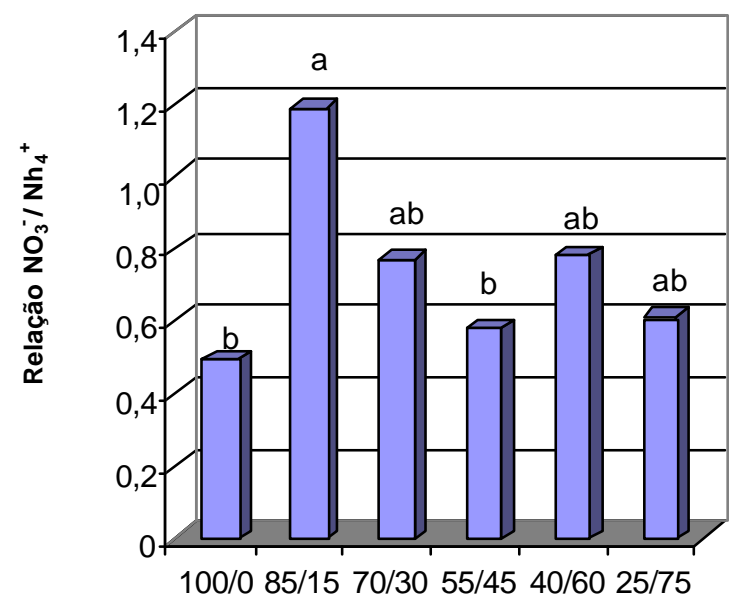

Proporções de nitrato/amônio

Figura 48 - Relação nitrato/amônio nas lâminas de folhas maduras no primeiro corte do capim-Aruana, em função das proporções de nitrato e amônio na solução nutritiva. Letras diferentes indicam diferença entre médias pelo teste de Tukey $(P<0,05)$

Por ocasião dos dois cortes do capim-Marandu foi observado significância $(\mathrm{P}<0,01)$ para a relação nitrato:amônio nos colmos mais bainhas, em relação æ̀̀ proporções de nitrato e amônio na solução nutritiva. Pode-se observar que as relações nitrato/amônio foram similares nas proporções 100/0 e 70/30 no primeiro corte, e no segundo corte nas proporções 100/0, 85/15 e 70/30 (Figura 50 e 51). 


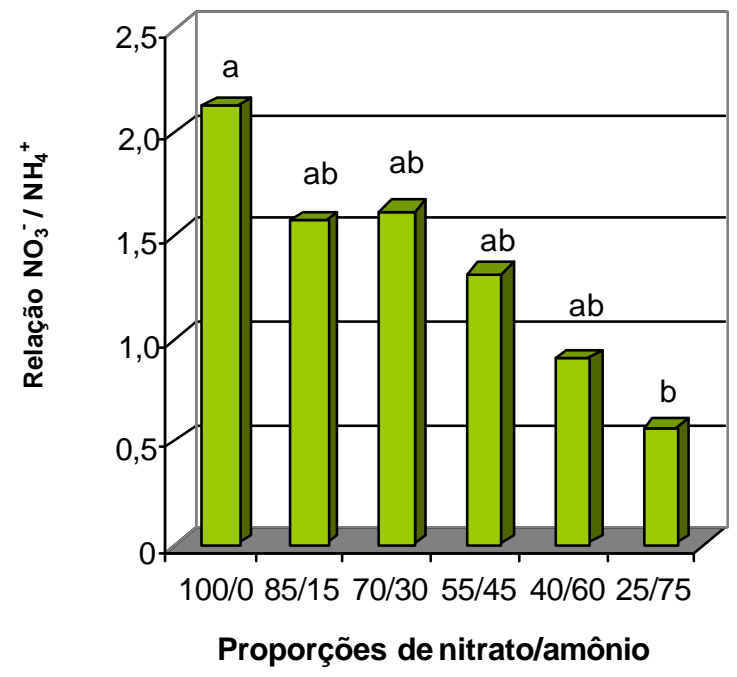

Figura 49 - Relação nitrato/amônio nas lâminas de folhas recém-expandidas no primeiro corte do capim-Marandu, em função das proporções de nitrato e amônio na solução nutritiva. Letras diferentes indicam diferença entre médias pelo teste de Tukey $(\mathrm{P}<0,05)$

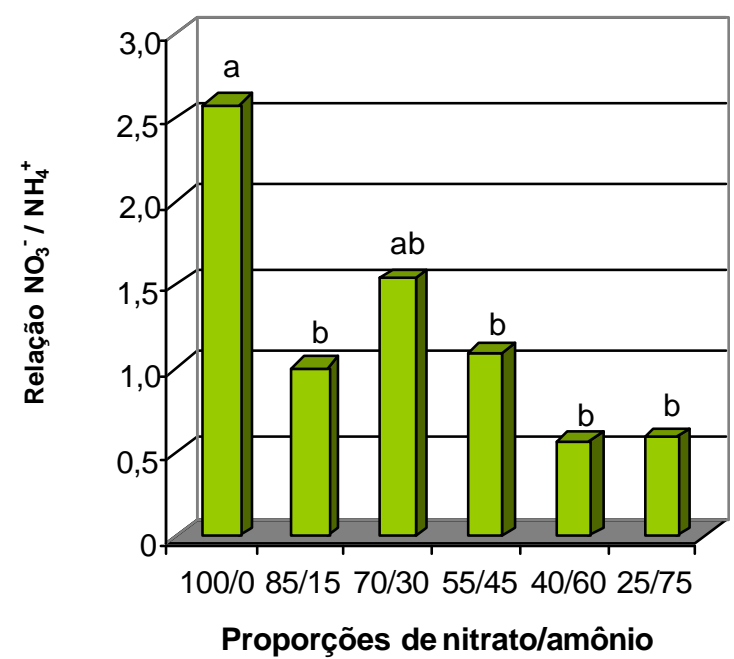

Figura 50 - Relação nitrato/amônio nos colmos mais bainhas no primeiro corte do capim-Marandu, em função das proporções de nitrato e amônio na solução nutritiva. Letras diferentes indicam diferença entre médias pelo teste de Tukey $(P<0,05)$ 


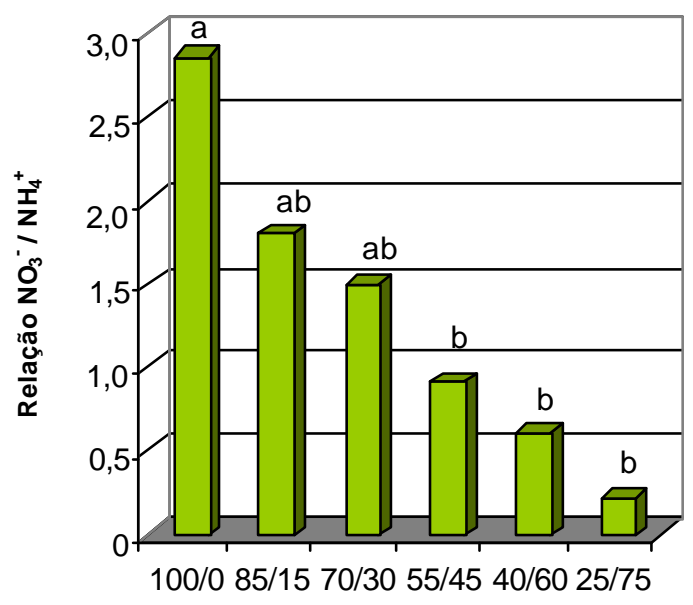

Proporções de nitrato/amônio

Figura 51 - Relação nitrato/amônio nos colmos mais bainhas no segundo crescimento do capim-Marandu, em função das proporções de nitrato e amônio na solução nutritiva. Letras diferentes indicam diferença entre médias pelo teste de Tukey $(P<0,05)$

\subsubsection{Raízes}

As proporções de nitrato e amônio na solução nutritiva resultaram em alterações significativas $(P<0,05)$ na relação nitrato/amônio nas raízes do capimAruana. A comparação entre médias apontou que as relações $\mathrm{NO}_{3}{ }^{-} / \mathrm{NH}_{4}{ }^{+}$não diferiram entre si (Figura 52).

Os resultados da relação nitrato/amônio nas raízes do capim-Marandu, evidenciaram variação significativa $(P<0,01$, em relação æ̀ proporções de nitrato $e$ amônio na solução nutritiva. Observa-se que essas relações nas proporções de nitrato e amônio 100/0 e 85/15 não diferiram entre s, porém foram mais elevadas que naquelas de 70/30, 55/45 e 40/60 (Figura 53). 


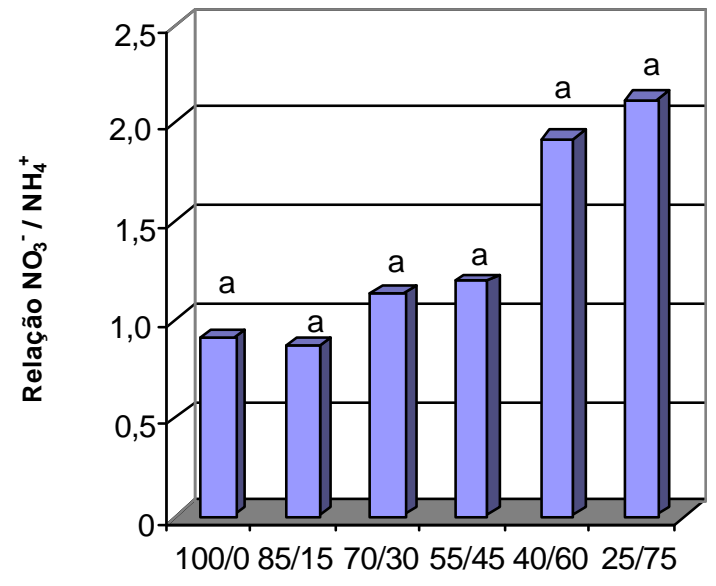

Proporções de nitrato/amônio

Figura 52 - Relação nitrato/amônio nas raízes do capim-Aruana, em função das proporções de nitrato e amônio na solução nutritiva. Letras diferentes indicam diferença entre médias pelo teste de Tukey $(P<0,05)$

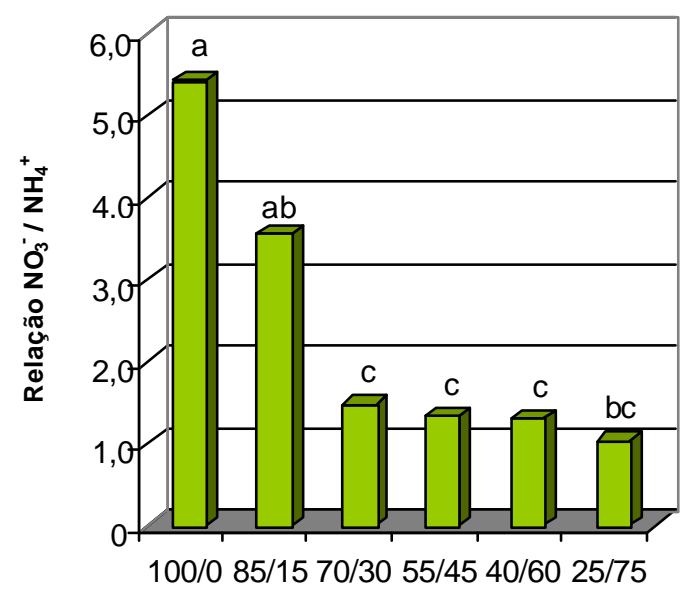

Proporções de nitrato/amônio

Figura 53 - Relação nitrato/amônio nas raízes do capim-Marandu, em função das proporções de nitrato e amônio na solução nutritiva. Letras diferentes indicam diferença entre médias pelo teste de Tukey $(P<0,05)$ 


\subsection{Superfície total e comprimento total das raízes}

A análise de variância dos resultados referentes à superfície total de raízes do capim-Aruana revelou significância $(P<0,05)$ para as proporções de nitrato e amônio fornecidas na solução nutritiva. Constatou-se que a superfície total do sistema radicular não apresentou diferença estatística entre as proporções 85/15, 70/30, 55/45 e 40/60, mas que a proporção de 55/45 foi superior às de 100/0 e 25/75 (Figura 54).

Lavres Junior (2001) observou que para a superfície total de raízes do capimMombaça, houve significância $(P<0,01)$ para o nitrogênio fornecido na solução nutritiva, e verificou que a máxima superfície de raízes seria obtida com o nitrogênio na dose de $812 \mathrm{mg} \mathrm{L}^{-1}$, formada pela proporção 64,4/35,6 de nitrato/amônio ressaltando, assim, a importância do nitrogênio para o crescimento do sistema radicular da planta.

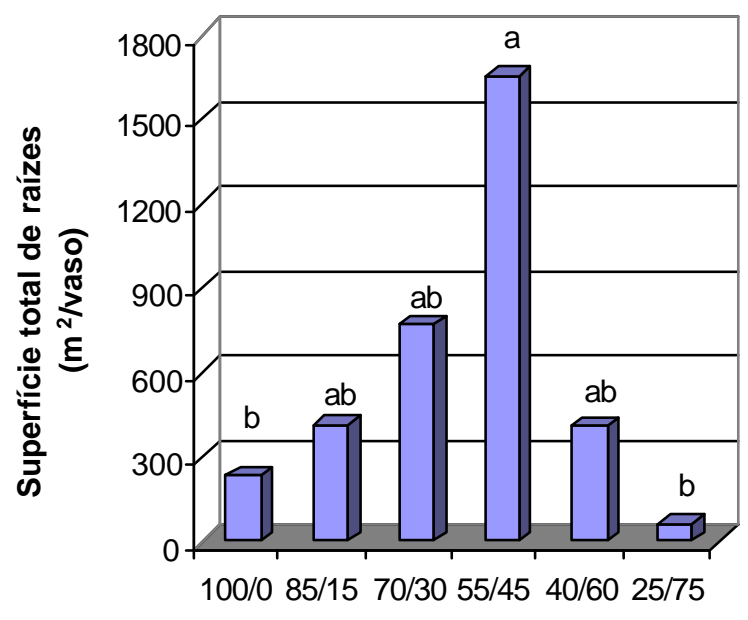

Proporções de nitrato/amônio

Figura 54 - Superfície total de raízes por vaso do capim-Aruana, em função das proporções de nitrato e amônio na solução nutritiva. Letras diferentes indicam diferença entre médias pelo teste de Tukey $(P<0,05)$ 
No comprimento total de raízes do capim-Aruana foi verificada significância $(\mathrm{P}<0,01)$ para as proporções de nitrato e amônio fornecidas na solução nutritiva. Observou-se que as proporções 85/15, 70/30, 55/45 e 40/60 não difereriram estatísticamente entre si, mas houve diferença entre as proporções 55/45 e de 100/0 e 25/75 (Figura 55).

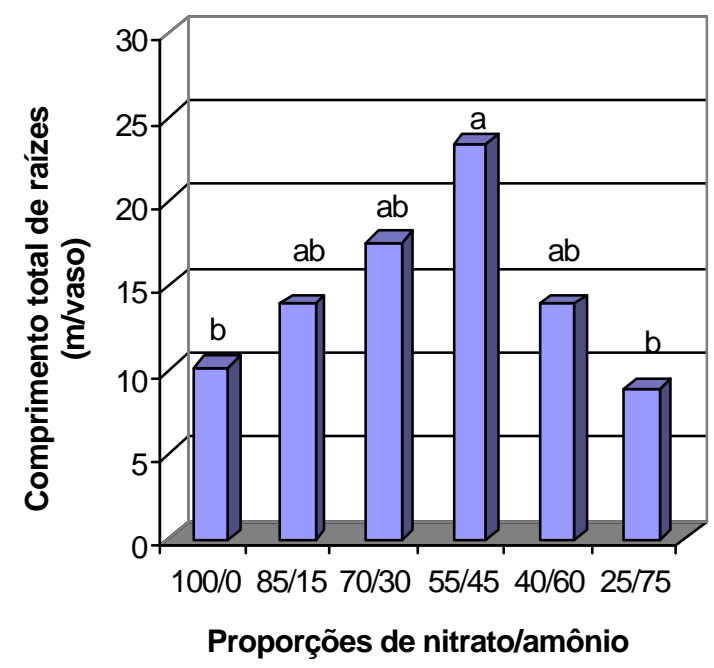

Figura 55 - Comprimento total de raízes por vaso do capim-Aruana, em função das proporções de nitrato e amônio na solução nutritiva. Letras diferentes indicam diferença entre médias pelo teste de Tukey $(P<0,05)$

A superfície total radicular do capim-Marandu variou significativamente $(P<0,01)$ com as proporções de nitrato e amônio fornecidas na solução nutritiva. Pode-se observar que a proporção de 70/30 de nitrato/amônio foi a que resultou em maior superfície total de raíz (Figura 56).

Batista (2002) observou significância $(P<0,01)$ para superfície total de raízes do capim-Marandu em função das doses de nitrogênio fornecidas na solução nutritiva, constatando que o fornecimento de nitrogênio de $450 \mathrm{mg} \mathrm{L}^{-1}$ foi o que ressaltou em maior superfície total do sistema radicular. 


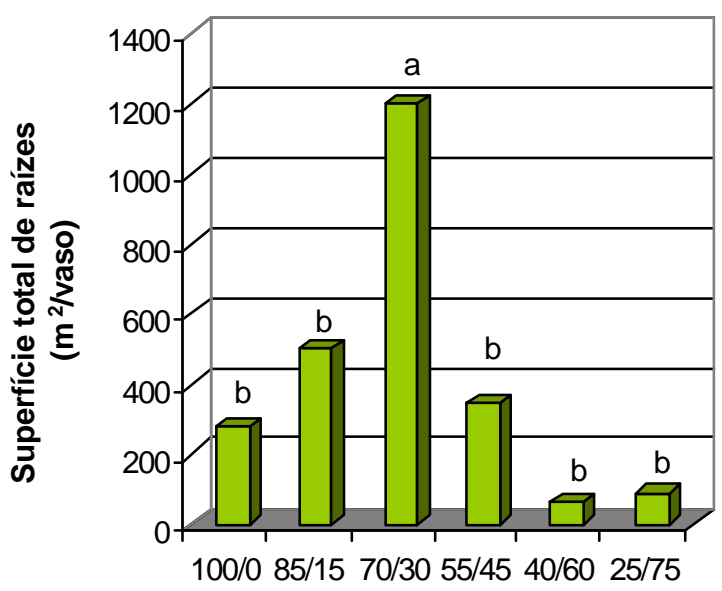

Proporções de nitrato/amônio

Figura 56 - Superfície total de raízes por vaso do capim-Marandu, em função das proporções de nitrato e amônio na solução nutritiva. Letras diferentes indicam diferença entre médias pelo teste de Tukey $(P<0,05)$

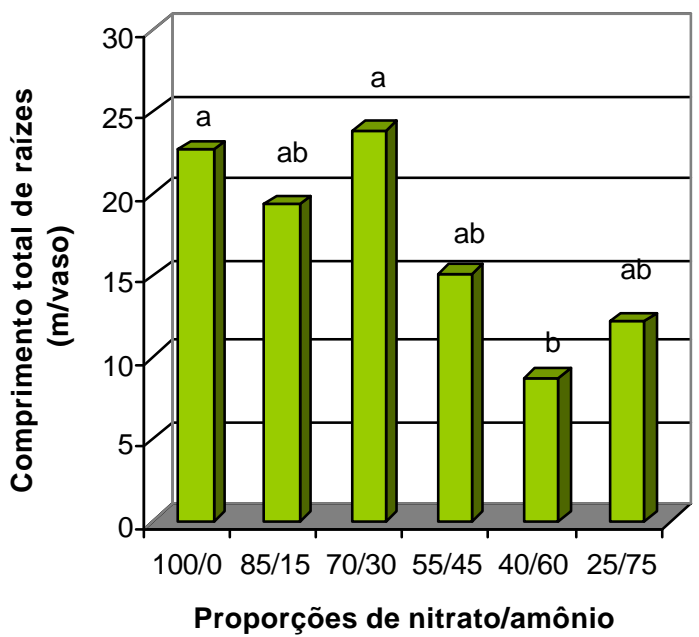

Figura 57 - Comprimento total de raízes por vaso do capim-Marandu, em função das proporções de nitrato e amônio na solução nutritiva. Letras diferentes indicam diferença entre mé dias pelo teste de Tukey $(P<0,05)$ 
Para o comprimento total de raízes do capim-Marandu observou-se que houve significância $(\mathrm{P}<0,01)$ para as proporções de nitrato e amônio. O maior comprimento total de raízes foi verificado nas proporções de 100/0, 85/15, 70/30, 55/45 e 25/75 de nitrato/amônio (Figura 57).

Batista (2002) ressaltou que houve significância $(\mathrm{P}<0,01)$ para o comprimento de raízes do capim-Marandu, em relação ao nitrogênio fornecido na solução nutritiva, constatando que a dose de $210 \mathrm{mg} \mathrm{L}^{-1}$ composta pela proporção 70/30 de nitrato/amônio não foi responsável pelo maior comprimento total de raízes. Resultado esse obtido na dose de 399,6 $\mathrm{mg} \mathrm{L}^{-1}$. Também nessa concentração o comprimento total de raízes foi $88 \%$ mais elevado que o presente na mais baixa dose de nitrogênio $\left(14 \mathrm{mg} \mathrm{L}^{-1}\right)$. 


\section{CONCLUSÕES}

Conclui-se que os capins Aruana e Marandu:

$\sqrt{ }$ Incrementam o número de perfilhos e número de folhas nas plantas quando as proporções de nitrato/amônio situam-se entre 85/15 e 55/45;

$\sqrt{ }$ Repondem favoravelmente em área foliar e massa seca da parte aérea com 0 nitrogênio fornecido em proporções de 100/0 a 55/45 de nitrato/amônio;

$\sqrt{ }$ Tem mais massa seca, superfície e comprimento de raízes com fornecimento conjunto de nitrato e amônio, em proporções de 70/30 e 55/45;

$\sqrt{ }$ Apresentam mais elevada concentração de nitrogênio total nos colmos mais bainhas e de nitrogênio na forma amoniacal na lâminas de folhas maduras nos casos de aplicação de nitrato e amônio nas proporções de 40/60 e 25/75;

$\sqrt{ }$ Revelam prejuízos nos atributos produtivos quando a proporção nitrato/amônio é de 25/75;

$\sqrt{ }$ Beneficiam-se da substituição de parte do nitrato por amônio na solução completa de Sarruge. 


\section{REFERÊNCIAS BIBLIOGRÁFICAS}

ABREU, J. B. R. Níveis de nitrogênio e proporções de nitrato e amônio afetando produção, atividade da redutase do nitrato e composição de três gramíneas forrageiras. Piracicaba, 1994. 103p. Dissertação (Mestrado) - Escola Superior de Agricultura “Luiz de Queiroz”, Universidade de São Paulo.

ABREU, J. B. R.; MONTEIRO, F. A. Produção e nutrição do capim-Marandu em função de adubação nitrogenada e estádios de crescimento. Boletim de Indústria Animal, v.56, n.2, p.137-146, 1999.

ADAMS, F. Nutritional imbalances and constrainst to plant growth on acid soils. Journal of Plant Nutrition, v.4, n.2, p.81-87, 1981.

ALVIM, M. J.; BOTREL, M. A.; VERNEQUE, R. S.; SALVATI, J. A. Aplicação de nitrogênio em acessos de Brachiaria. 1. Efeito sobre a produção de matéria seca. Pasturas Tropicales, v.12, n.2, p.2-6, 1990.

ANDRADE, S. R. M. Efeito da proporção $\mathrm{NH}_{4}^{+}: \mathrm{NO}_{3}^{-}$na composição da fração nitrogenada e na atividade das enzimas de redução e assimilação de nitrogênio em plantas de capim-Colonião (Panicum maximum Jacq.). Viçosa, 1994. 49p. Dissertação (Mestrado) - Universidade Federal de Viçosa.

ARONOVICH, S.; ROCHA, G. L. Gramíneas e leguminosas forrageiras de importância no Brasil Central Pecuário. Informe Agropecuário, v.11, n.132, p.3-13, 1985. 
ARONOVICH, S. O capim colonião e outros cultivares de Panicum maximum Jacq.: Introdução e evolução do uso no Brasil. In: SIMPÓSIO SOBRE MANEJO DE PASTAGEM, 12., Piracicaba, 1995. Anais. Piracicaba: FEALQ, 1995. p.1-20.

BATISTA, K. Respostas do capim-Marandu a combinações de doses de nitrogênio e enxofre. Piracicaba, 2002. 91p. Dissertação (Mestrado) - Escola Superior de Agricultura "Luiz de Queiroz", Universidade de São Paulo.

BLACQUIERE, T.; VOORTMAN, E. ; STULEN, I. Ammonium and nitrate nutrition in Plantago lanceolata L. and Plantago major L. ssp. major. II. Nitrogen metabolism. Plant and Soil, v.106, n.1, p. 23-24, 1988.

BOGDAN, A. V. Tropical pasture and fodder plants. London: Longman, 1977. 455p.

BROWER, R. Nutritive influences on the distribuition of dry matter in the plant. Netherlands in the plants. Netherlands Journal of Agricultural Science, v.10, n.5, p.399-408, 1962.

CARVALHO, M. M.; MARTINS, C. E.; VERNEQUE, R. S.; SIQUEIRA, C. Respostas de uma espécie de Brachiaria à fertilização com nitrogênio e potássio em um solo ácido. Revista Brasileira de Ciência do Solo, v.15, n.2, p.195-200, 1991.

CHASE, A. Grasses of Brazil and Venezuela. Agriculture in the Americas, v.4, n.7, p.123-126, 1944.

COLOZZA, M. T. Rendimento e diagnose foliar dos capins Aruana e Mombaça cultivados em Latossolo Vermelho-Amarelo. Piracicaba, 1998. 127p. Tese (Doutorado) - Escola Superior de Agricultura "Luiz de Queiroz", Universidade de São Paulo.

COLOZZA, M. T.; KIEHL, J. C.; WERNER, J. C.; SCHAMMASS, E. A. Respostas de Panicum maximum cultivar Aruana a doses de nitrogênio. Boletim de Indústria Animal, v.57, n.1, p.21-32, 2000. 
CORRÊA, B. D. Doses de nitrogênio e magnésio afetando aspectos produtivos e biquímicos dos capins Colonião, Tanzânia-1 e Vencedor. Piracicaba, 1996. 76p. Dissertação (Mestrado) - Escola Superior de Agricultura "Luiz de Queiroz", Universidade de São Paulo.

CORSI, M. O clima e a produção de forragem. In: SIMPÓSIO SOBRE MANEJO DA PASTAGEM, 1., Piracicaba, 1973. Anais. Piracicaba: ESALQ, 1973. p.181-204.

CORSI, M. Adubação nitrogenada das pastagens. In: SIMPÓSIO SOBRE MANEJO DA PASTAGEM, 2., Piracicaba, 1975. Anais. Piracicaba: ESALQ, 1975. p.112-142.

CORSI, M. Effects of nitrogen rates and harvesting intervals on dry matter production, tillering and quality of the tropical grass Panicum maximum Jacq. Ames, 1984. 125p. Thesis (PhD) - The Ohio State University.

CORSI, M. Manejo de plantas forrageiras do gênero Panicum. In: SIMPÓSIO SOBRE MANEJO DA PASTAGEM, 9., Piracicaba, 1988. Anais. Piracicaba: FEALQ, 1988. p.57-75.

CORSI, M.; SANTOS, P. M. Potencial de produção do Panicum maximum. In: SIMPÓSIO SOBRE MANEJO DA PASTAGEM, 12., Piracicaba, 1995. Anais. Piracicaba: FEALQ, 1995. p.275-303.

CORSI, M.; MARTHA JÚNIOR, G. B. Manutenção da fertilidade do solo em sistemas intensivos de pastejo rotacionado. In: SIMPÓSIO SOBRE MANEJO DA PASTAGEM, 14., Piracicaba, 1997. Anais. Piracicaba: FEALQ, 1997. p.161-192.

CRESTANA, S.; GUIMARÃES, M. F.; JORGE, L. A. C.; RALISH, R.; TOZZI, C. L.; TORRE, A. ; VAZ, C. M. P. Avaliação da distribuição de raízes no solo auxiliada por processamento de imagens digitais. Revista Brasileira de Ciência do Solo, v.18, n.3, p.365-371, 1994. 
FERNANDES, M. S.; ROSSIELLO, R. O. P. Aspectos do metabolismo e utilização do nitrogênio em gramíneas tropicais. In: SIMPÓSIO SOBRE CALAGEM E ADUBAÇÃO DE PASTAGENS, 1., Nova Odessa, 1985. Anais. Piracicaba: Potafós, 1986. p.93-123.

FERRAGINE, M. C. Combinação de doses de nirogênio e potássio na nutrição mineral de capim-braquiária. Piracicaba, 1998. 84p. Dissertação (Mestrado) - Escola Superior de Agricultura "Luiz de Queiroz", Universidade de São Paulo.

HAGEMAM, R. H. Integration of nitrogenassimilation in relation to yield. In: HEWIT, E. J. \& CUTTINGS, C. v. (Ed.). Nitrogen assimilation in plants. New York, Academic Press, 1979. p. 591-612.

HAGEMAM, R. H.; BELOW, F. E. Role of nitrogen metabolism in crop productivity. In: $A B R O L, Y$. P. (Ed.). Nitrogen in higher plants. Somerset: England Research Studies, 1990. p.313-334.

HOFFMANN, C. R. Nutrição mineral e crescimento da braquiária e do colonião, sob influência das aplicações de nitrogênio, fósforo, potássio e enxofre em Latossolo da região noroeste do Paraná. Lavras, 1992. 204p. Dissertação (Mestrado) Escola Superior de Agricultura de Lavras.

HOPKINS, W. G. Introduction to plant physiology. New York: John Wiley, 1995. $464 p$.

IZ - Instituto de Zootecnia Comercializa sementes de capim Aruana. http://homepage.barao.iac.br/IZ/Produtos/vende_de_sementes_de_capim_ar.htm (03/2002).

JANK, L.; COSTA, J. C. G. Avaliação, seleção e lançamento de novos cultivares de gramíneas da espécie Panicum maximum. In: ENCONTRO NACIONAL SOBRE PRODUÇÃO DE SEMENTES DE PLANTAS FORRAGEIRAS, 4, 1990. Anais. 1990. p.1-15. 
JANK, L. Potencial do gênero Panicum. In: SIMPÓSIO BRASILEIRO DE FORRAGEIRAS E PASTAGENS, Campinas, 1994. Anais. Campinas:CBNA, 1994. p.25-31.

KANNO, T.; MACEDO. M. C. M.; EUCLIDES, V. P. B.; BONO, J. A.; SANTOS JUNIOR., J. D. G.; ROCHA, M. C.; BERETTA, L. G. R. Root biomass of five tropical grass pastures under continuous grazing in Brazilian Savannas. Grassland Science, v.45, n.1, p.9-14, 1999.

LAVRES JUNIOR, J. Combinações de doses de nitrogênio e potássio para o capim-Mombaça. Piracicaba, 2001. 103p. Dissertação (Mestrado) - Escola Superior de Agricultura "Luiz de Queiroz", Universidade de São Paulo.

MALAVOLTA, E.; HAAG, H. P.; MELLO, F. A. F.; BRASIL SOBRINHO, M. O. C. Nutrição mineral de plantas cultivadas. São Paulo: Pioneira, 1974. 724p.

MANARIN, C. A. Respostas fisiológicas, bioquímicas e produtivas do capim-Mombaça a doses de nitrogênio. Piracicaba, 2000. 58p. Dissertação (Mestrado) - Escola Superior de Agricultura "Luiz de Queiroz", Universidade de São Paulo.

MARSCHNER, H. Mineral nutrition of higher plants. 2. ed. London: Academic Press, 1995. 889p.

MENGEL, K.; KIRKBY, E. A. Principles of plant nutrition. 5. ed. Dordrecht: Kluwer Academic, 2001. 849p.

MILLS, H. A.; BARKER, A. V.; MAYNARD, D. N. Effects of nitrapyrin on nitrate accumulation in spinach. Journal of the American Society for Horticultural Science, v.101, n.3, p.202-204, 1976.

MINOLTA CAMARA Co. Manual for chlorophyll meter Spad - 502. Osaka, 1989. 22p. 
MONTEIRO, F. A. Forrageiras. In: FERREIRA, M. E.; CRUZ, M. C. P. (Ed.) Micronutrientes na agricultura Piracicaba: Potafós, 1991.p.651-681.

MONTEIRO, F. A.; RAMOS, A. K. B.; CARVALHO, D. D.; ABREU, J. B. R.; DAIUB, J A. S.; SILVA, J. E. P.; NATALE, W. Cultivo de Brachiaria brizantha Stapf. cv. Marandu em solução nutritiva com omissões de macronutrientes. Scientia Agrícola, v.52, n.1, p.135-141, 1995.

MONTEIRO, F. A.; WERNER, J. C. Reciclagem de nutrientes nas pastagens. In: SIMPÓSIO SOBRE MANEJO DA PASTAGEM,14., Piracicaba, 1997. Anais. Piracicaba: FEALQ, 1997. p.55-84.

MULDER, E. G.; BOXMA, R.; VAN VEEN, W. L. The effect of molybdenum and nitrogen deficiencies on nitrate reduction in plant tissue. Plant and Soil, v.10, n.4, p.335-355, 1959.

NAMBIAR, P. T. C.; REGO, T. J.; RAO, B. S. Nitrate concentration and nitrate reductase activity in the leaves of three legumes and three cereals. Annals of Applied Biology, v.112, n.3, p.547-553, 1988.

NOLLER, C. H.; RHYKERD, C. L. Relationship of nitrogen fertilization and chemical composition of forage to animal health and performance. In: MAYS, D. A. (Ed.). Forage fertilization. Madison: American Society of Agronomy, 1974. cap.17, p.363-387.

NUNES, S. G.; BOOK, A.; PENTEADO, M. I. O.; GOMES, D. T. Brachiaria brizantha cv. Marandu. Campo Grande: Embrapa, CNPGC, 1985. 31p. (Embrapa. CNPGC. Documento, 21).

PAULINO, V. T.; SHUNKE, R.; CANTARELLA, H. Avaliação do nível de nitrogênio em quatro cultivares de Panicum maximum Jacq. através da média indireta de clorofila (Compact disc). In: REUNIÃO ANUAL DA SOCIEDADE BRASILEIRA DE ZOOTECNIA, 35., Botucatu, 1998. Anais. Botucatu: SBZ, 1998. 
RAIJ, B. van. Fertilidade do solo e adubação. Piracicaba: Agronômica Ceres: POTAFOS, 1991. 343p.

RAO, I.; KERRIDGE, P.; MACEDO, M. C. Nutritional requirements of Brachiaria and adaptation to acid soils. In: MILLES, J. W.; MAASS, B. L.; VALLE, C. B. (Ed.). Brachiaria: biology, agronomy and improvement. Cali: CIAT;Brasília: Embrapa, CNPGC, 1996. p.53-71.

RENVOIZE, S. A.; CLAYTON, W. D.; KABUYE, C.H.S. Morphology, taxonomy and natural distribution of Brachiaria. In: MILES, J. W.; MAASS, B. L.; VALLE, C. B. (Ed.). Brachiaria: biology, agronomy and improvement. Cali: CIAT;Brasília: Embrapa, CNPGC, 1996, p.1-15.

RODRIGUES, R. C. Calcário, nitrogênio e enxofre para a recuperação do capimBraquiária cultivado em solo proveniente de uma pastagem degradada. Piracicaba, 2002. 141p. Dissertação (Mestrado) - Escola Superior de Agricultura "Luiz de Queiroz", Universidade de São Paulo.

Rossielo, R. O. P.; ARAúJO, A. P.; MANZATtO, C. V.; FeRnANDES, M. S. Comparação dos métodos fotoelétricos e da interação na determinação de área, comprimento e raio médio radicular. Pesquisa Agropecuária Brasileira, v.30, n.5, p.633-638, 1995.

RUFTY Jr., T. W. .; THOMAS, J. F.; REMMLEER, J. L.; CAMPBEL, W. H.; VOLK, R. J. Intracellular localization of nitrate reductase in roots. Plant Physiology, v.82, n.3, p.675-680, 1986.

SANTOS, A. R. Diagnose nutricional e respostas do capim-braquiária submetido a doses de nitrogênio e enxofre. Piracicaba, 1997. 115p. Tese (Doutorado) - Escola Superior de Agricultura "Luiz de Queiroz", Universidade de São Paulo. 
SANTOS, A. R.; CORRÊA, B. D.; MONTEIRO, F. A. Efeito de níveis de nitrogênio sobre o rendimento de matéria seca, teor de nitrogênio e perfilhamento em Panicum maximum cultivar Vencedor. In: CONGRESSO BRASILEIRO DE CIÊNCIA DO SOLO, 25., Viçosa, 1995. Resumos. Viçosa: SBCS; UFV, 1995. p.741-742.

SANTOS JUNIOR, J. D. G dos. Dinâmica de crescimento e nutrição do capimMarandu submetido a doses de nitrogênio. Piracicaba, 2001. 79p. Dissertação (Mestrado) - Escola Superior de Agricultura "Luiz de Queiroz", Universidade de São Paulo.

SARRUGE, J. R. Soluções nutritivas. Summa Phytopatologica, v.1, n.3, p.231-233, 1975.

SARRUGE, J. R.; HAAG, H. P. Análises químicas em plantas. Piracicaba: ESALQ, 1974. 54p.

SAS INSTITUTE. SAS/STAT : users guide; version 6. 4. Cary, 1989. v.2, 846p.

SCHIAVUZZO, P. F.; MONTEIRO, F. A.; LAVRES JUNIOR, J. Nitrogênio na produção e na nutrição da braquiária-Marandu. In: REUNIÃO ANUAL DA SOCIEDADE BRASILEIRA DE ZOOTECNIA, 37., Viçosa, 2000. Resumos. Viçosa: SBZ, 2000. p.107.

SERGER, C. C. D.; SANCHEZ, L. M B. Teores minerais em pastagens do Rio Grande do Sul. I - Cálcio, fósforo, magnésio e potássio. Brasília-DF: EMBRAPA. v.31, n.12, p.898-904, 1996.

SILVEIRA, J. S. M. Crescimento e composição da fração nitrogenada solúvel em plantas de capim-Colonião (Panicum maximum Jacq.), em função de várias proporções nitrato/amônio. Viçosa, 1981. 36p. Dissertação (Mestrado) Universidade Federal de Viçosa. 
SOARES FILHO, C. V. Recomendações de espécies e variedades de Brachiaria para diferentes condições. In: SIMPÓSIO SOBRE MANEJO DA PASTAGEM, 11., Piracicaba, 1994. Anais. Piracicaba: FEALQ, 1994. p.25-48.

SOUZA, F. H. D. Panicum maximum in Brazil. In: LOCH, D. S.; FERGUSON, J. E. Forage seed production. New York: CABI, 1999. v.2. Tropical and subtropical species. p.363-370.

TAIZ, L.; ZIEGER, E. Assimilation of mineral nutrients. In: Plant physiology. Redwood City: The Benjamin/Cumminggs., 1991. cap.12, p.292-317.

TEDESCO, M. J.; VOLKWEISS, S. J.; BOHEN, H. Análise de solos, plantas e outros materiais. Porto Alegre: Universidade Federal do Rio Grande do Sul, 1985. 188p. (Boletim Técnico, 5).

TISDALE, S. L.; NELSON, J. L.; BEATON, J. D. Soil fertility and fertilizers. 4.ed. New York: Macmillan, 1985. 754p.

VALLEJOS, A.; PIZARRO, E. A.; CHÁVES, C.; PEZO, D.; FERREIRA, P. Evaluación agronómica de gramíneas en Guapiles, Costa Rica. 2. Ecotipos de Panicum maximum. Pasturas Tropicales, v.11, n.2, p.10-15, 1989.

VITTI, G. C.; LUZ, P. H. C. Calagem e uso do gesso agrícola em pastagens. In: SIMPÓSIO SOBRE ECOSSISTEMA DE PASTAGENS, 3., Jaboticabal, 1997. Anais. Jaboticabal:Funep, 1997. p.63-111.

VITTI, G. C.; MALAVOLTA, E.; COUTINHO, E. L. M. Uso eficiente de fertilizantes nitrogenados e portadores de enxofre. In: SIMPÓSIO SOBRE FERTILIZANTES NA AGRICULTURA BRASILEIRA, Ilhéus, 1984. Anais. Embrapa: Ilhéus, 1984. p.205-253. 
WERNER, J. C.; QUAGLIATO, J. L. ; MARTINELLI, D. Ensaio de fertilização do Colonião com solo do "Noroeste". Boletim de Indústria Animal, v.24, n.1, p.159167, 1967.

WERNER, J. C. Adubação de pastagens. Nova Odessa: Instituto de Zootecnia, 1986. 49p. (IZ. Boletim Técnico, 18).

WILKINSON, S. R.; LANGDALE, G. W. Fertility needs of the warm-season grasses. In: MAYS, D. A. (Ed.). Forage fertilization. Madison: American Society of Agronomy, 1974. cap.6, p.119-145.

ZIMMER, A. H.; MACEDO, M. C. M.; BARCELOS, A. O.; KICHEL, A. N. Estabelecimento e recuperação de pastagens de Brachiaria. In: SIMPÓSIO SOBRE MANEJO DA PASTAGEM, 11., Piracicaba, 1994. Anais. Piracicaba: FEALQ, 1994. p.153-208. 